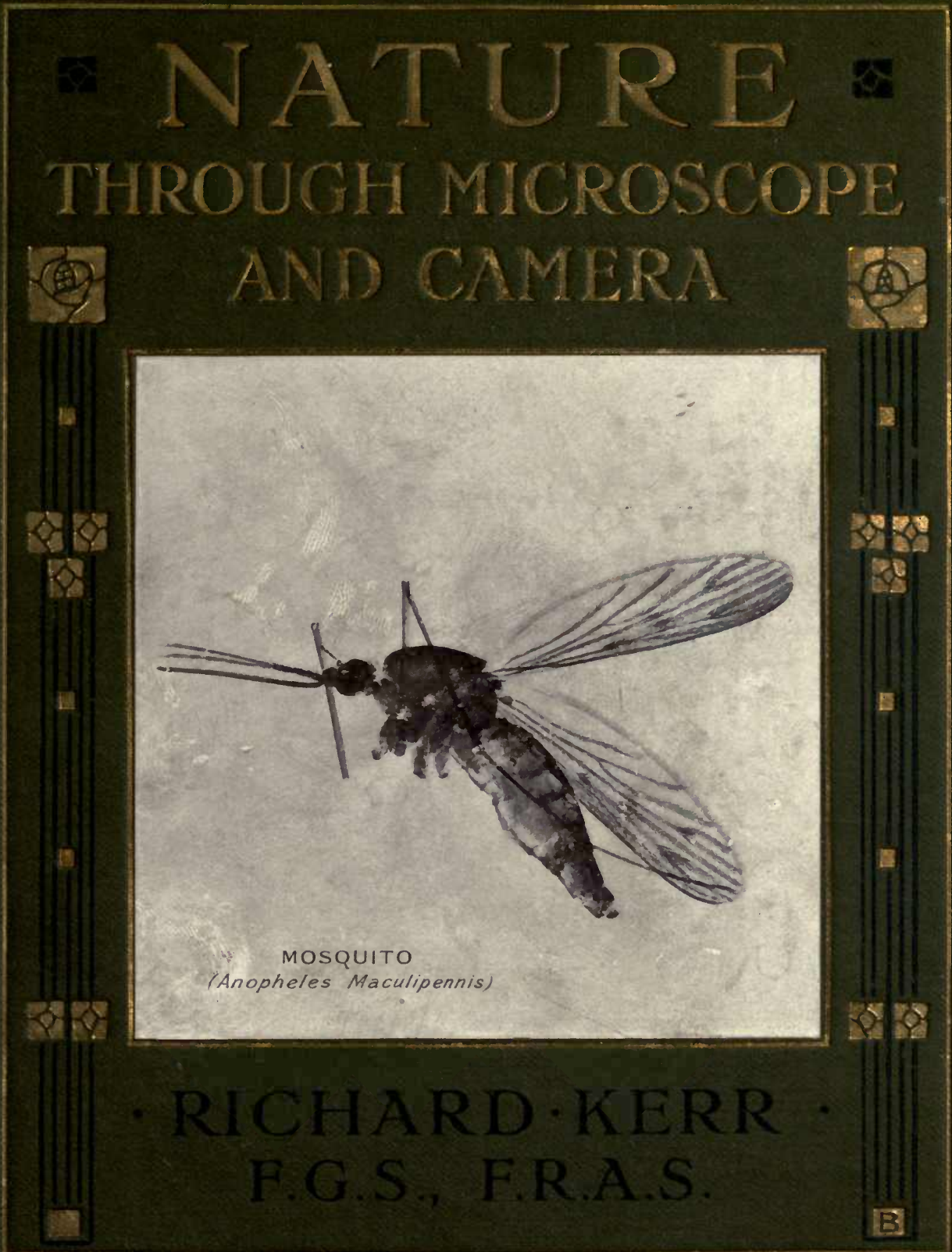

WITH PHOTO-MICROGRAPHS BY 


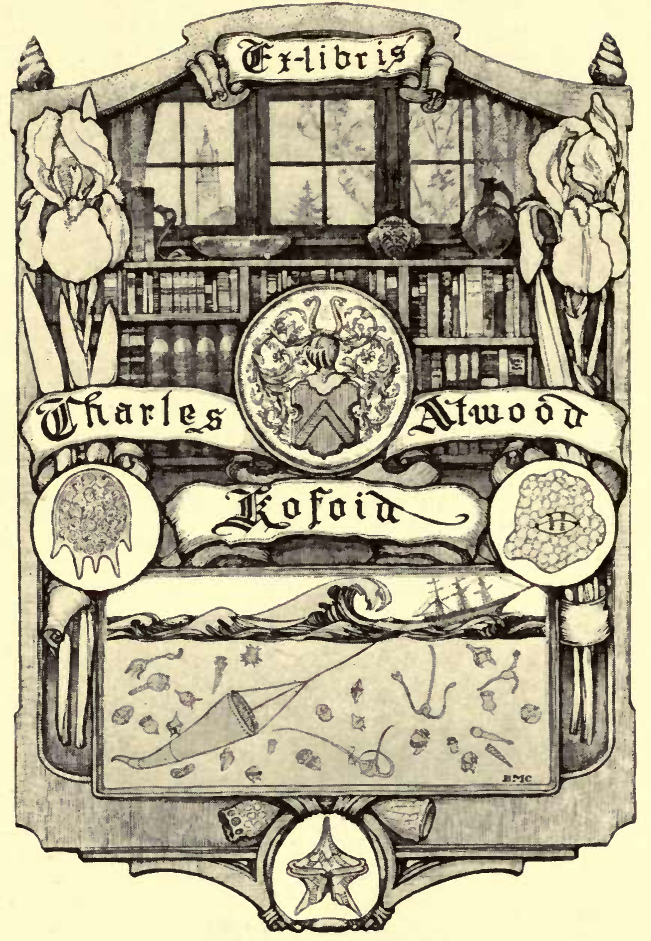




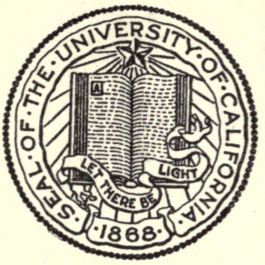

THE LIBRARY OF

\section{THE UNIVERSITY OF CALIFORNIA}

PRESENTED BY

PROF. CHARLES A. KOFOID AND MRS. PRUDENCE W. KOFOID 


BY THE SAME aUTHOR.

\section{Nature-Curious and}

\section{Beautiful.}

With Eighty-nine Illustrations. Crown $8 \mathrm{vo}$, cloth gilt, $3 s .6 d$.

\section{Hidden Beauties of} Nature.

With Fifty-nine Illustrations. Crown

8vo, cloth gilt, 2 s. $6 d$.

LONDON

THE RELIGIOUS TRACT SOCIETY

4 Bodverie Streit, E.C. 


\section{NATURE-THROUGH MICROSCOPE AND CAMERA}


' $\mathrm{O}$, there are curious things of which men know As yet but little! Secrets lying hid Within all natural objects. Be they shells, Which ocean flingeth off her billows, Or the low sand or flowers, or trees, or grasses, Covering the earth; rich metals or bright ores Beneath the surface. He who findeth out Those secret things hath a fair right to gladness; For he hath well performed, and doth awake Another note of praise on Nature's harp To hymn her Great Creator.'

'To the Natural Philosopher there is no natural object that is unimportant or trifling; from the least of Nature's works he may learn the greatest lessons.'-Sir J. F. W. Herscher. 



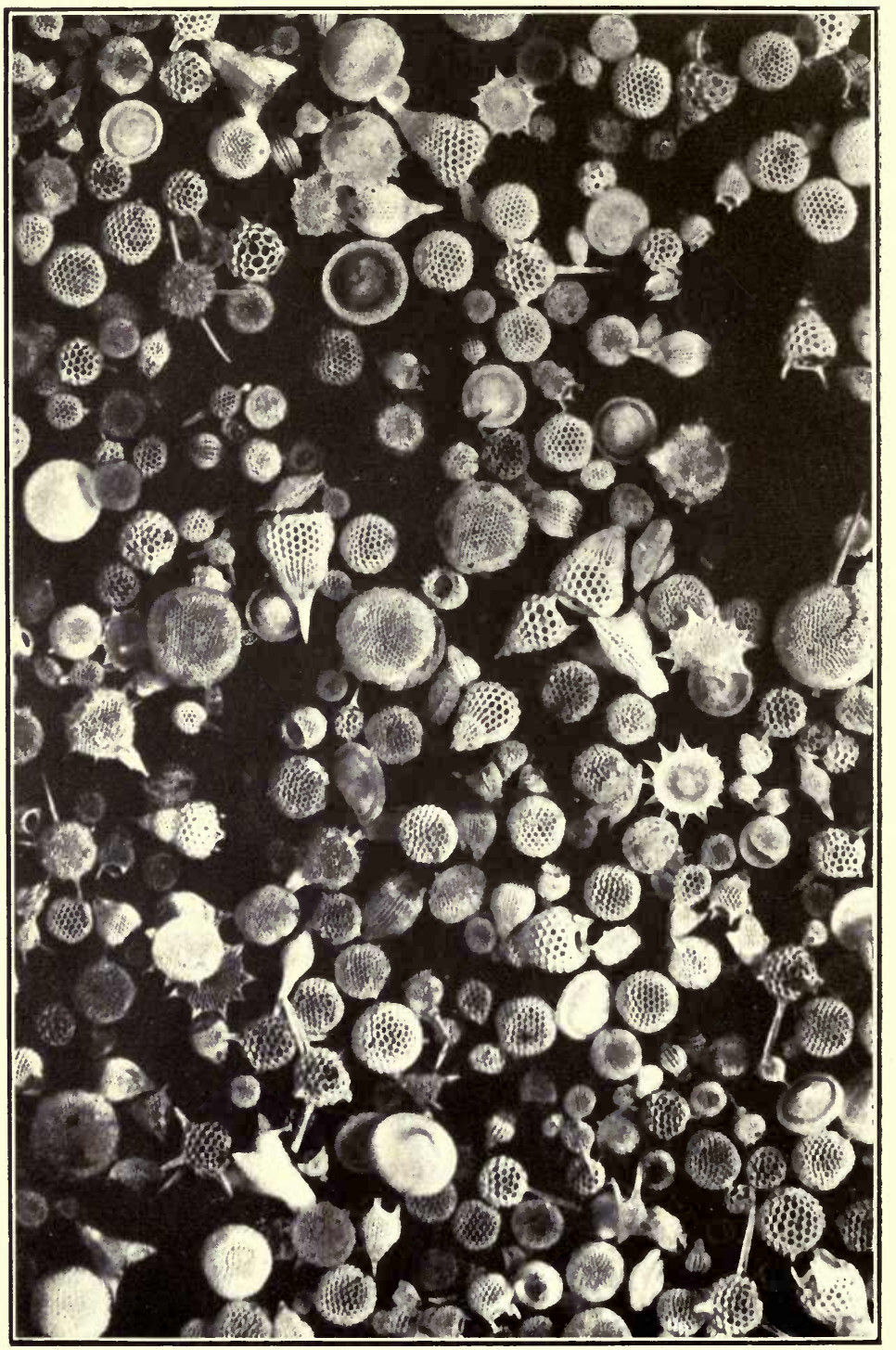

FIG, I.

POLYCYSTINA FROM BARBADOS. 


\section{NATURE}

\section{THROUGH}

\section{MICROSCOPE \& CAMERA}

BY

RICHARD KERR, F.G.S., F.R.A.S.

AUTHOR OF 'NATURE-CURIOUS AND BEAUTIFUI,'

'HIDDEN BEAUTIES OF NATURE,' ETC.

WITH SIXTY=FIVE PHOTO=MICROGRAPHS

BY

ARTHUR E. SMITH

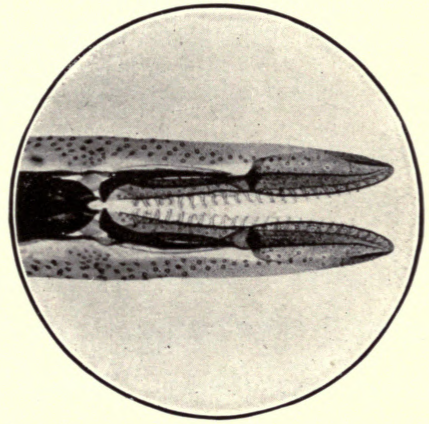

TONGUE OF RHYNGIA

$\times 25$.

SECOND IMPRESSION

LONDON

THE RELIGIOUS TRACT SOCIETY

4 Bouverie St. \& 65 St. Paul's Churchyard 



\section{INTRODUCTION}

BY G. SIMS WOODHEAD, M.A. M.D.,

Profegsor of Pathology, Cambridge.

THOSE who have once attempted to catch 1 a glimpse of the wonderful secrets that Nature will unveil to the earnest and discreet searcher can never again look upon things as common or of little importance because they do not display to the eye of the superficial observer the beauties that lie hidden under an unattractive appearance or are shrouded in size so minute that the ordinary eye is incapable of discerning their exquisite plan and detail.

The ingenious and beautifully finished works projected by the human brain and brought into being by the human hand attract our attention and compel our admiration. We are constrained to admit that the telescope, the microscope, the 
steam-engine or the watch, to say nought of those rare works of art that from age to age have been described as perfect of their kind, are wondrously beautiful; and beautiful they are, but in comparison with some of the exquisite objects subjected to the photographer's art in the following pages they are indeed coarse and crude. The writing of the Lord's Prayer on a surface no larger in area than that covered by a threepenny piece is looked upon as a great piece of penmanship, but how the lines so made suffer by comparison with some of the objects here photographed. The delicate tracery of the Heliopelta metii (Fig. 3), of the beautiful diatom from Bori, in Hungary (Fig. 5), or of the Coscinodiscus bi-angulatus (Fig. 4), can only be properly 'resolved' or brought into view by the use of magnifications so great that if applied to an object one inch in length they would make it appear to be nearly sixty-eight yards long, or would magnify the finest, most beautiful silk that the spinner and weaver can produce into something far rougher than a wattle fence or a fabric woven of ship's cables. 



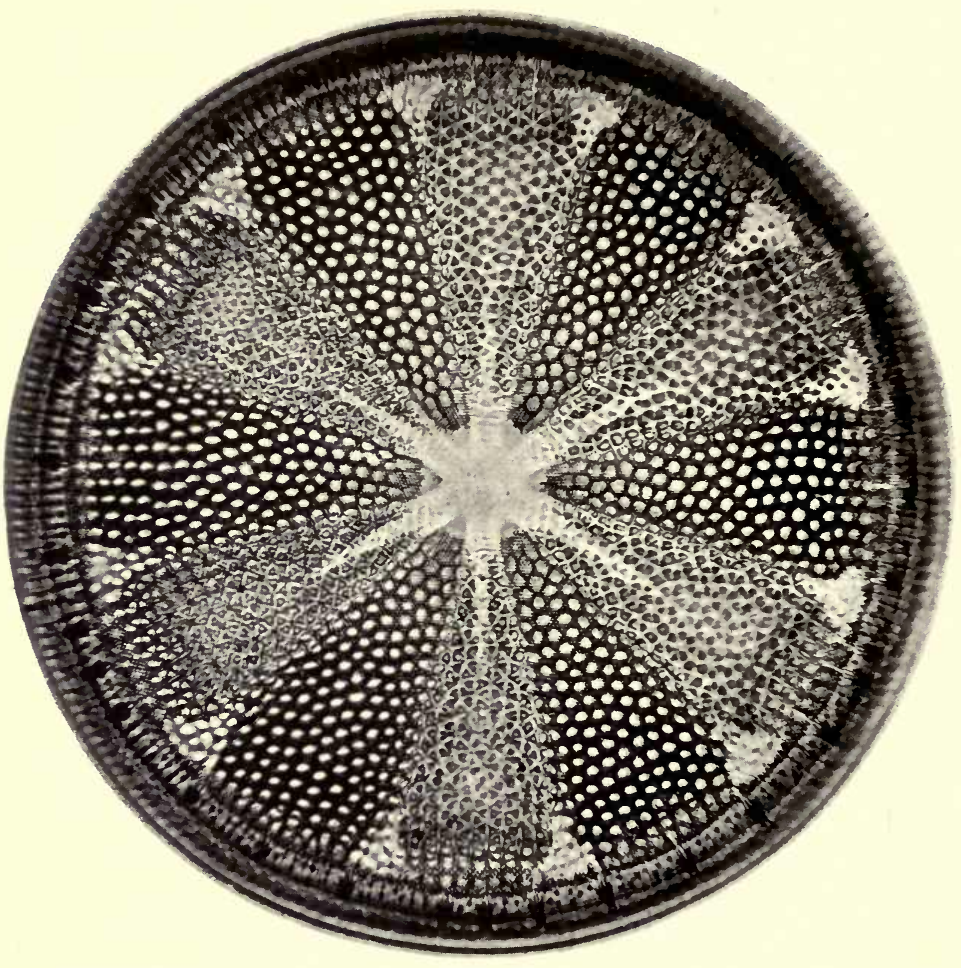

FIG. 3 .

DIATOM, HELIOPELTA METII.

$\times 350$.

[to face p. 7 . 
It would be mere repetition of what the author has put down in description and explanation of the plates to give further illustration of the contrast that obtains between man's crude handiwork and the many beautiful objects that have here been brought under the lens of the photographic camera.

And such a camera! I have seen many collections of micro-photographs, and I have examined many of the microscopic objects here delineated, but never before have I fully realised either the beauty of the objects themselves or the possibilities bound up in the method by which these beauties have been reproduced, and so rendered accessible to others than those skilled in the use of the microscope.

The author and artist have gone over a wide range of subjects, and have selected excellent examples from each section of this range, and any one who will take the trouble to examine a single one of the photographs will be anxious to cover the whole ground. When he has so gone over this ground he should, if he is an observant and thinking man, arise from the 


\section{THE VERY 'GARMENT OF GOD'}

contemplation of these structures filled with wonder at their perfection and with reverence for the Power that conceived and brought about their construction. No one can believe that such things were created accidentally or by chance; law appears in every organism, care and design in every detail. Here is something more than a mere crystallisation of like particles from a liquid of a specific composition, wonderful though that process is. Here we have thousands upon thousands of exquisite forms each one accurately reproduced or modified to meet slightly altered conditions and to fit into slightly altered surroundings. We have different forms of living matter from plants and animals, we have dead or inorganic matter snatched from its dead mass and converted by this living matter into wondrously beautiful structures. Can we believe that behind all this design there is no great designer-that, in fact, this is not the very 'garment of God'?

An honest attempt to get at the truth is never to be feared. Truth is truth, and may always be sought fearlessly. Truth can never turn out 
anything but truth, and those who are engaged in the investigation of natural phenomena have little fear that anything we learn concerning these phenomena can have any permanent influence in undermining the essentials of our religious belief.

It is sometimes maintained that the study of natural science has a tendency to render men less earnest in their study of religion; indeed, many people look upon a knowledge of natural science and a study of 'evolution' as being incompatible with the existence of a religious faith. Why should we abstain from studying the marvellous works that are around us on every side, even though we cannot expect to understand them all? 'Never let what you know be disturbed by what you don't know.' In many cases it is impossible for us to follow the process of evolution and growth of God's wonderful works. Do we say that they do not exist because we do not understand them? Should we not rather accept them in all their beauty and with all their evidence of design as an indication that there is a designer? If in 
these material things we accept what appeals to our natural senses and take much more for granted, are we justified in taking the position of the agnostic, and rejecting everything of the spiritual life that we cannot understand? Should it not be maintained that the more we become convinced of our ignorance concerning natural phenomena the more ready shall we be to accept all that is good and beautiful in Christ (and Christianity), without insisting on a full understanding by our finite minds of much that He taught and did?

Even those phenomena which we look upon as every-day occurrences are to many of us almost sealed books. We say that we know all about them,-but do we? We have merely scratched the surface of such knowledge; we have not reached the heart of it. We know little -more of the causes, of the forces that are at work than we know of some of the miracles that were recorded nearly a couple of thousand years ago. Behind all these beautiful works there appears to be a great reasoning Power, a Power that controls, One infinitely above our 


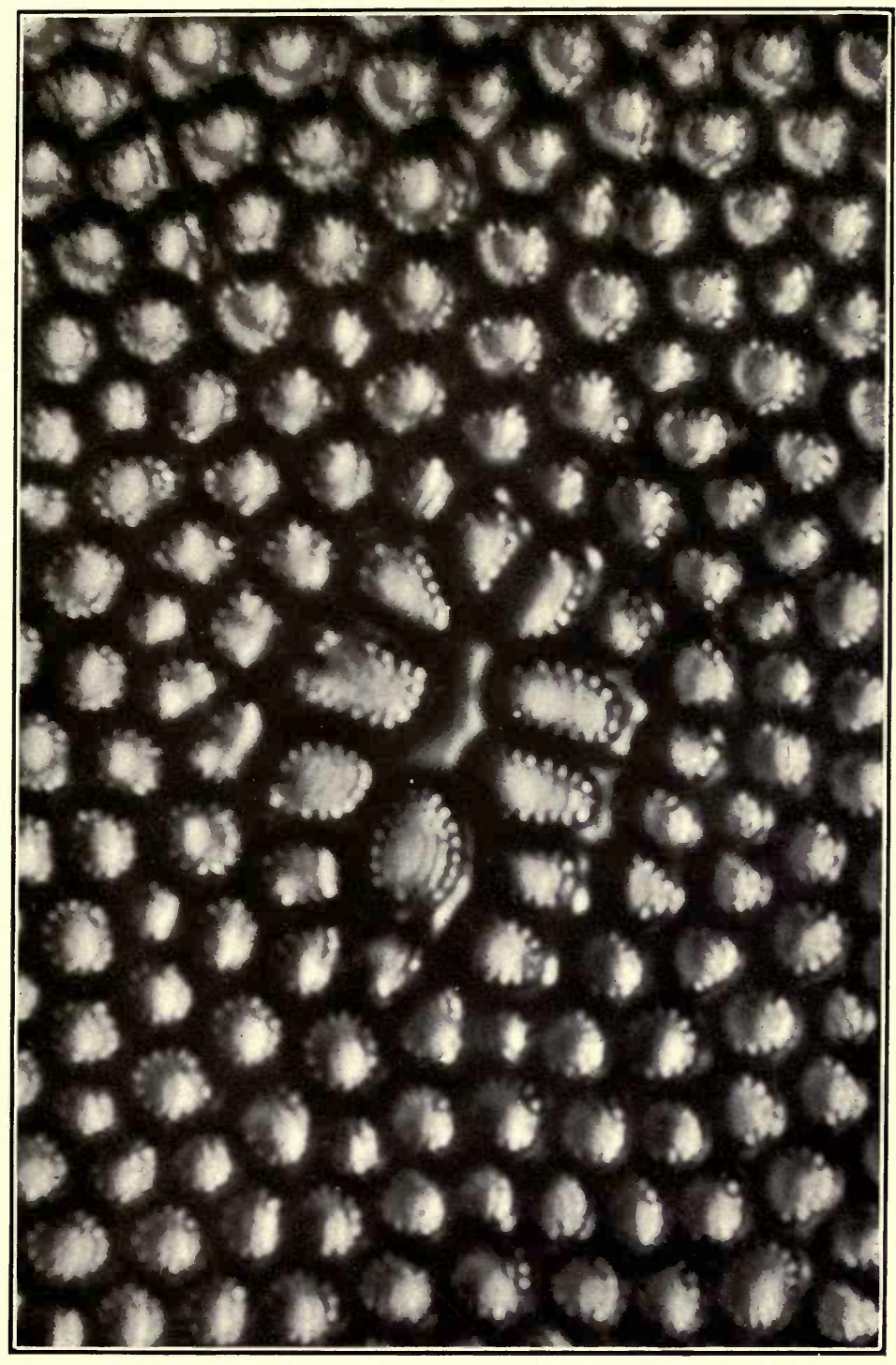

FIG. 4 .

PAR' OF A DIATOM, COSCINODISCUS BI-ANGULATUS. 

understanding. Such a thought as this must recur to every one who is dealing with Nature's problems. Let me give an example, one often used. I have had to study, as have all doctors, the process of healing. Here one sees how in a short time after the infliction of a wound a series of phenomena of wonderful beauty but of great complexity are manifested. First, blood, or some of its component parts, forms a temporary stop-gap, filling up the wound from top to bottom; then the wounded tissues in the immediate neighbourhood of such temporary stop-gap begin to undergo change: they multiply, forming new, embryonic, or imperfectly developed tissues. After a time these young tissues, at first pierced by numerous new bloodvessels, become fully developed, and the gap is filled up with permanent tissue. If we look at these processes merely from the outside and from the purely materialistic point of view, we may say that these living cells multiplying and forming new tissues are bringing about the healing of the wound. But are we much nearer any explanation of what lies behind ? We are com- 
pelled to confess that here are factors beyond our comprehension. We say that these living tissues are doing certain things, but we don't know how or why they live, what they are doing or how they do it. We may attempt to explain life as a chemical or a physical process, or as a combination of such processes, but there always comes a point at which we get beyond our depth and we have to fall back on what we call vitality, and we pretend to explain things by using terms which seem to convey more than we really understand. We have learnt a few facts, a few elementary details concerning the marvels of Nature's laboratory, but the more we learn the more must we be impressed by the fact that above all that we can see and beyond all that we can understand there is a great power, a power which pervades, moves, controls, and guides. Sometimes in our intellectual conceit we may claim that we are able to explain all things of which we have had some experience, but if we will only be honest with ourselves we find that our explanations are not explanations at all. We 
are merely recording observations or expressing opinions, often very ill-founded. We are not going to the real centre of things. We are no doubt learning something of the machinery of Nature and of the world, yet in our hearts we know that if we leave out God we have nothing left for the power that guides, controls, and pervades that machinery.

Now and again we may be satisfied with partial, and what are called natural explanations. Far more frequently, however, we know that we are not satisfied. We know, indeed, that God is necessary to us, and that $\mathrm{He}$ must reign in the world and in us before we can have any sense of satisfaction in our existence. It has often been said that intellectual conceit tends to unbelief-a conceit more characteristic even of the age just passed than of the present generation. In former years, with the sudden opening out of our knowledge of natural phenomena there has always been a tendency on the part of those who studied Nature, and who tried to wrest from her her hidden treasures, to accept nothing that they could 
not explain as a result of their own observation and deduction and for which they could not find an immediate and demonstrable cause. Men have wrestled long and patiently with Nature that they might wring from her her secrets; they have built up schemes and systems, and in the end have come to think that anything that cannot be fitted into one of these systems must be useless and may be thrown aside. They have said we have for long enough accepted authority as our guide, and it would seem that the agnosticism of to-day, or of yesterday rather, may be accepted as a reaction against doctrines and dogmas based solely upon, and supported by, what was termed authority.

Let those who are afraid of the teachings of natural science take to heart Weismann's words: 'Although I regard the doctrine of descent as proved, and hold it to be one of the greatest acquisitions of human knowledge, I must repeat that I do not mean to say that everything is clear in regard to the evolution of the living world. On the contrary, I believe 
that we still stand merely on the threshold of investigation, and that our insight into the mighty process of evolution, which has brought about the endless diversity of life upon our earth, is still very incomplete in relation to what may yet be found out, and that, instead of being vainglorious, our attitude should be one of modesty. We may well rejoice over the great step forward which the dominant recognition of the evolution theory implies, but we must confess that the beginnings of life are as little clear to us as those of the solar system. But we can do this at least: we can refer the innumerable and wonderful interrelations of the organic cosmos to their causes-common descent and adaptation-and we can try to discover the ways and means which have co-operated to bring the organic world to the state in which we know it. ... We shall see that the recognition of a law-governed evolution of the organic is not more prejudicial to true religion than is the revolution of the earth round the sun.'

We may learn something from this book of 
the laws of Nature. But we must always remember that what we call the laws of Nature are merely a codification of our own experience and observation. Those who will study such laws and the basis on which they are founded will, we believe, feel bound to accept them as additional evidence of the existence of God, with whom rest all powers of law and order and to whom the supernatural is unknown, though $\mathrm{He}$ may know and make manifest many things which may not accord with our finite ideas of the orderly, and may not fall in with our conception of the natural. 



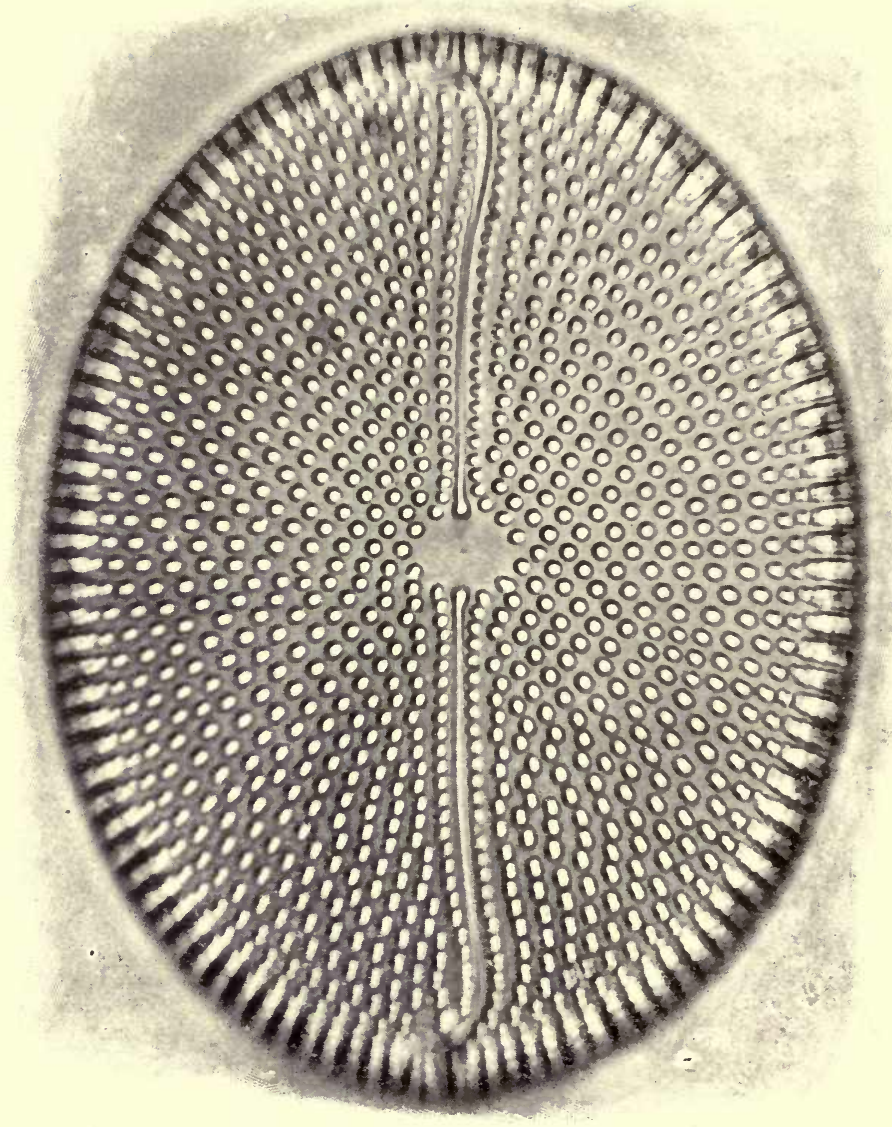

FIG. 5 .

DIATOM, FROM BORI, HUNGARY.

$\times 1000$.

to face poge i7. 


\section{AUTHOR'S INTRODUCTION}

CHARLES KINGSLEY has said, 'I have seen the cultivated man craving for travel, and for success in life, pent up in the drudgery of London work, and yet keeping his spirit calm, and perhaps his morals all the more righteous, by spending over his microscope evenings which would too probably have been gradually wasted at the theatre.'

This is strong testimony to the value of the microscope alone as an entertaining and civilising instrument. But the value of the instrument is increased enormously by the addition of the photographic camera. It is not at all necessary to have a huge camera like that represented in the illustration (Fig. 8). But of this we shall say something later. 
The uppermost thought in the minds of those who engage in photo-micrography, even in an elementary way, is, I fancy, What a vast amount of intellectual pleasure people miss who have no knowledge of these instruments, people too who could well afford to have them, and who, if so inclined, could use them with advantage in quarters where valuable time and money are spent at 'Bridge,' and where the powers of conversation rise no higher than in ecstatic admiration of some fancy dog.

'To Amuse, and not to Educate,' is an announcement we see on the hoardings. It expresses the spirit of the times in England. Amusement is the order of the day in dear old England; and other nations love to have it so, because the more we 'fool away' our time the more they employ their time and talents in raising the intellectual status of their countries, and as a result their commercial prosperity follows. They are to be commended, while our case is to be deplored.

It is not hinted for one moment that games and amusements should be abolished; such a 
suggestion would be absurd. But we cannot shut our eyes to the fact that there can be too much of the amusement fetich. It is overdone, and its devotees act as if the only aim in life is to be amused. The prosperity of the nation does not depend upon the amount of amusement that can be crammed into our lives, but upon the intellectual attainments of the units that make up the nation.

There are hundreds of thousands of people in certain counties whose whole conversation is permeated with football and cricket language, showing the uppermost and paramount thoughts in their minds.

It is not at all unlikely that this ' amusement and not education' desire is the cause of our trade finding its way barred by better work by other peoples, the cause of a good deal of the want of employment among our working classes, and the direct or indirect cause of an amount of poverty and crime.

There are too many places of amusement in our cities, too many trashy and pernicious novels read in our free libraries, too much time 
given to games, both in the upper and in the working classes, and not enough time nor attention given to those forms of intellectual recreation which improve the mind. Our boys are made physically strong, but is the mental development keeping pace with the physical? If not, our nation will deteriorate.

We do not suggest photography through the microscope as the remedy for existing defects, but we think that the more our young men take up intellectual pastimes the better it will be for the nation. This is one of those pastimes. It is not a selfish one. One enthusiast is a centre of usefulness to others, for he cannot keep to himself the enjoyment he receives from the study of Nature's beauties and wonders.

A section of the book is devoted to histological subjects intended specially for junior medical students. At the same time the illustrations and descriptions of all the subjects in this particular department ought to be familiar to every one. The enormous work done by the heart, the wonderful structure 
of a human hair, and that of the skin, \&c., are all points well worth our attention. There is nothing in Nature, so far as we know it, that is more wonderful than the human body, even considered from the histologist's standpoint. Our education is incomplete if we have shunned all knowledge of our own system and its wonders.

The illustrations are entirely original. Nothing from these negatives has ever been published excepting the 'spider's foot,' which appeared in the July number of 'Knowledge' as a whole-page illustration.

An expression of our indebtedness is due to Mr. Henry Tavener for his new discovery and his permission to illustrate it-the Mideopsis orbicularis of pond water; also to Dr. Joseph A. Featherstone, of Tooting, for his kindness in describing the histological details of several sections illustrated.

RICHARD KERR. 



\section{BIBLIOGRAPHY}

\section{T $N$ the preparation of these chapters use has \\ 1 been made of the works noted below. If quotations have been made from any which are not entered in the following list, the omission is not intentional.}

The Cambridge Natural History. The Concise Knowledge Library.

Text-Book of Zoology. By Claus and Sedgwick.

A Treatise on Zoology. Ed. by E. Ray Lankester.

Text-Book of Physiology. By McKendrick. (J. Maclehose \& Sons.)

Text-Book of Human Physiology. By LandoIs and Stirling.

Kirkes' Handbook of Physiology. (John Murray.)

The Microscope and its Revelations. Ed. by DR. DALLINGER.

Systematic Botany. By Warming and Potter.

Microscopical Science. By CoLe.

The Micrographic Dictionary.

Botany. By SACHS.

Diseases of Field and Garden Crops. By Worthington G. Ммiтн. 
Students' Text-Book of Botany. By S. H. Vines.

Physiology of Plants.

Foraminifera. By Chapman.

Diatomaceæ. By Murus.

The Microscope. By JABEZ HoGG.

The Animal Kingdom. By Rymer Jones.

One Thousand Objects for the Microscope. By M. C. Cooke.

Handbook of Practical Botany. Strasburger and HillHOUSE.

A General System of Botany. Maout and Decaisne. 


\section{CONTENTS}

PAGE

INTRODUCTION BY G. SIMS WOODHEAD, M.A., M.D., PROFESSOR OF PATHOLOGY, CAMBRIDGE • • 5

AUTHOR'S INTRODUCTION $\quad$ - $\quad$ - $\quad$ - $\quad$. 17

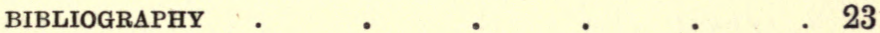

CEAPTER

I. THE ILLUSTRATIONS AND HIGH POSSIBILITIES WITH THE MICROSCOPE $\quad$. $\quad 29$

II. PRACTICAL HINTS ON PHOTO-MICROGRAPHY . 37

III. FOSSIL RADIOLARIA (POLYCYSTINA) AND FORAMINIFERA . . . . . 44

IV. RADULE, CIRRI OF BARNACLE AND SPINES OF ECHINI $\quad$ - $50 \quad$ - $50 \quad$. 57

V. INSECT LIFE, PROBOSCIS OF BLOW-FLY AND EGGS

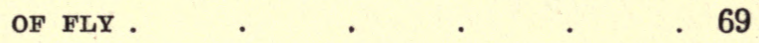

VI. BUTTERFLY'S TONGUE, EYE OF DYTISCUS, TONGUE OF BEE AND LEG OF BEE . $\quad$ • $\quad 79$

VII. MOSQUITO, AN INSECT NAVVY, AND RHYNGIA 90 VIII. HEAD OF CRANE FLY AND ANTENNA OF $\begin{array}{lllllllll}\text { MELOLONTHA } & \text { • } & \text { • } & 98\end{array}$ 


\section{CONTENTS}

CHAPTER

IX. DIATOMS

X. SECTIONS OF WHEAT STEMS, AND DODDER ON CLOVER

XI. STING OF NETTLE, ARISTOLOCHIA GIGAS AND CALAMUS ROTANG . . 123

XII. BUD OF LILY, VIRGIN'S BOWER, AND PETIOLE OF NUPHAR LUTEA . $\quad$. $\quad$. $\quad 133$

XIII. SPRUCE FIR, BUTCHERS' BROOM AND HIPPURIS VULGARIS

XIV. HUMAN HAIR .

XV. HUMAN SKIN, HEART MUSCLE (HUMAN) AND HUMAN BONE $\quad$. $\quad$. $\quad$. $\quad$. 152

XVI. HUMAN LUNG, RED CORPUSCLES, HUMAN TOOTH 163 XVII. PARASITES OF IGUANA, BUFFALO, SHEEP, AND BEE ; THE CHEESE MITE .

XVIII. A WATER-MITE (MIDEOPSIS ORBICULARIS), SPIDER'S FOOT AND WOLF SPIDER

xix. TETANUS (LOCKJAW) BACILLI; SCALES OF THE SOLE

XX. CIRCLET OF SCOLEX; SILK 


\section{LIST OF ILLUSTRATIONS}

FIG.

1. Polycystina from Barbados . - Frontispiece

2. Tongue of Rhyngia . . : Title-page

3. Diatom, Heliopelta metil • . - . 7

4. Part of a Diatom, Coscinodiscus Bi-angulatus 10

5. Diatom, from Bori, Hungary. . . 17

6. Diatom, Actinocyclus Ralfisi . . 32

7. Focussing the ObJect in the Microscope . 37

8. Focussing on the Camera Screen . $\quad 37$

9. Polycystina from Barbados . . . 44

10. Foraminifera.$\quad$. 50.52

11. Radula of Whelk . $\quad$. $\quad$. 56

12. Radula of WhelK. . ..$\quad 57$

13. Radula of Limpet $\quad . \quad$. $\quad . \quad \ldots 1$

14. Cirri of Barnacle . . . . . 65

15. Echinus Spine Section . . . 68

16. Proboscis of Blow-fly . $\quad . \quad$. 71

17. Part of Fly's Proboscis .

18. EgGs of House-Fur . . . . $\quad 77$

19. Butterfly's Tongue . $\quad$. $\quad$ • 80

20. Portion of Beetle's Eye. . . . . 81

21. Foot of Water Beetre (Dytiscus marginalis) 83

22. Tongue of Honey Bee . . . . 86

23. Part of Honer Bee's Hind Leg . 88

24. Gnat (Culex pipiens) . $\quad$. $\quad$. $\quad$. 89

25. Mosquito (Anopheles maculipennis). $\quad 91$

26. Larva of ANT-Lion. . . . . . $\quad$. 94

27. RHYNGIA.

28. Head of Crane Flu

29. Antenna of Cockchafer (Melolontha) • 101

30. Diatom, Navicula lyka $\quad . \quad$. $\quad . \quad 103$

31. Diatom, Triceratium favus . . 106 
FTG.

32. Diatom, Triceratium favus, var. Seprangulatum 108

33. Section of Wheat-stem . . 110

34. Section of Wheat-stem through the Node .113

35. Dodder on Clover . $\quad$. $\quad$. $\quad 118$

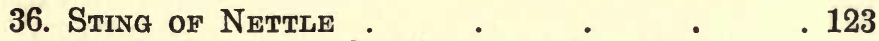

37. Stem Section Aristolochia gigas . 128

38. Stem Section Rattan Cane (Calamus rotang) 131

39. Section of Lily Bud . . . . 133

40. Seotion of Stem of Exogen (Clematis vitalba) 135

41. Transterse Section of Plant Stem (Nuphar

LUTEA) . $\quad$. $\quad$ • . . 138

42. Spruce Fir, Stem Section $\quad . \quad 140$

43. Section of Stem of Butchers' Broom - 142

44. Stem of Section of Mare's TaIn (Hippuris VULGARIS) .

45. Vertical Section of Human Scalp . 147

46. Transverse Section of Human Scalp • 149

47. Human Skin, Vertical Section . . 156

48. Heart Musche . . . . . . 158

49. Transterse Section of Human Bone - 160

50. Section of Human Lung . . . . 163

51. Human Blood . . . . . 165

52. Human Tooth, Vertical Section 167

53. Kitten's Jaw, Vertical Section • $\quad 170$

54. Parasite of Lizard (Ixodes of Iguana) 172

55. Hzmatopinus OF Buffalo . . . 174

56. Sheep Tick ..$\quad$. $\quad . \quad$. 177

57. Parasite of Bee (Braula cerca) . 178

58. Cheese Mite . . . . . . 180

59. Mmeopsis ORBICULARIS $\quad$. $\quad$. 181

60. Spider's Foot and Part of Leg. $\quad 183$

61. Wolf Spider . . . . . . 184

62. Tetanus (Lockjaw) Bacilmi . . 187

63. Scales on Skin of a Sole . . $\quad 190$

64. Circhet of Hooks on a Scolex . . 193

65. Fine Sirk . . . . . . 194 


\section{CHAPTER I}

\section{THE ILLUSTRATIONS AND HIGH POSSIBILITIES WITH THE MICROSCOPE}

\section{The Illustrations.}

THE illustrations have been taken from 1 photo-micrographs done on 12 by 10 plates directly through the microscope and camera combined as one instrument. The negatives have received no 'touching-up' whatever.

They were exhibited at the Royal Society's Annual Conversazione, May 13, 1904. In the catalogue is the following summary of the exhibit :-

'Examples of Photo-Micrography. The exhibit includes sections of histological, botanical, and entomological specimens, intended to assist 
students of biology generally and medical students especially. The camera used is unusually large in order to ensure direct photography. In no case are the results produced from the enlargement of small negatives.'

Subsequently we were invited to exhibit them at the Conversazione of the London University held at the Imperial Institute, May 27.

When photographs are enlarged from small negatives there is no material gain as regards new details. The advantage of a large camera (Fig. 3) is shown in several of the illustrations where a vast amount of design is visible which could not be secured by ordinary enlargements.

We are well aware that with the electric light or even the oxy-hydrogen lime-light, time could be saved as regards the exposures; but for general workers it is better to show what can be done with ordinary means of illumination, than to lead them to think that the electric or other light is indispensable.

The extra large camera is not absolutely necessary in all cases of photo-micrography, 
but for certain diatoms and other objects that display excessively minute structure it has its advantages, some of which, we hope, are apparent in the illustrations.

Excellent results have been obtained by primitive or homely methods and appliances. In fact two or three boxes telescopically arranged will answer all the ordinary purposes of an elaborate camera fitted with long bellows.

In photographing the features of the human being it is customary to submit the negatives to a system of re-touching. The photographers would do very little of this were it not for the vanity of their customers, and they would do very little photography if they were to omit the re-touching process.

But as regards the photography of microscopic objects it is a mistake to add any line or to make any object look as we would wish it to look. Drawings from microscopic objects often betray this defect.

No artists' license should be resorted to beyond reducing the density of, or strengthen- 
ing the negative. The personal equation must be left out, for it is hardly likely that any naturalist can suggest an improvement in the design of a diatom, of a radiolarian, or of a section of an ordinary plant. Laplace, the famous French astronomer, and undoubtedly one of the greatest astronomers of any nation, thought he could suggest a much better position in the heavens for the Moon (see Richard Proctor's The Expanse of Heaven, chap. ii.). Similarly, to judge by the interpretation put by some on the structure of minute forms of life, daring, if not conceit, manifests itself in a surprising degree.

Shakespeare teaches us all a lesson on this point :-

'To gild refined gold, to paint the lily,

To throw a perfume on the violet,

To smooth the ice or add another hue

Unto the rainbow, or with taper-light

To seek the beauteous eye of heaven to garnish,

Is wasteful and ridiculous excess.' 


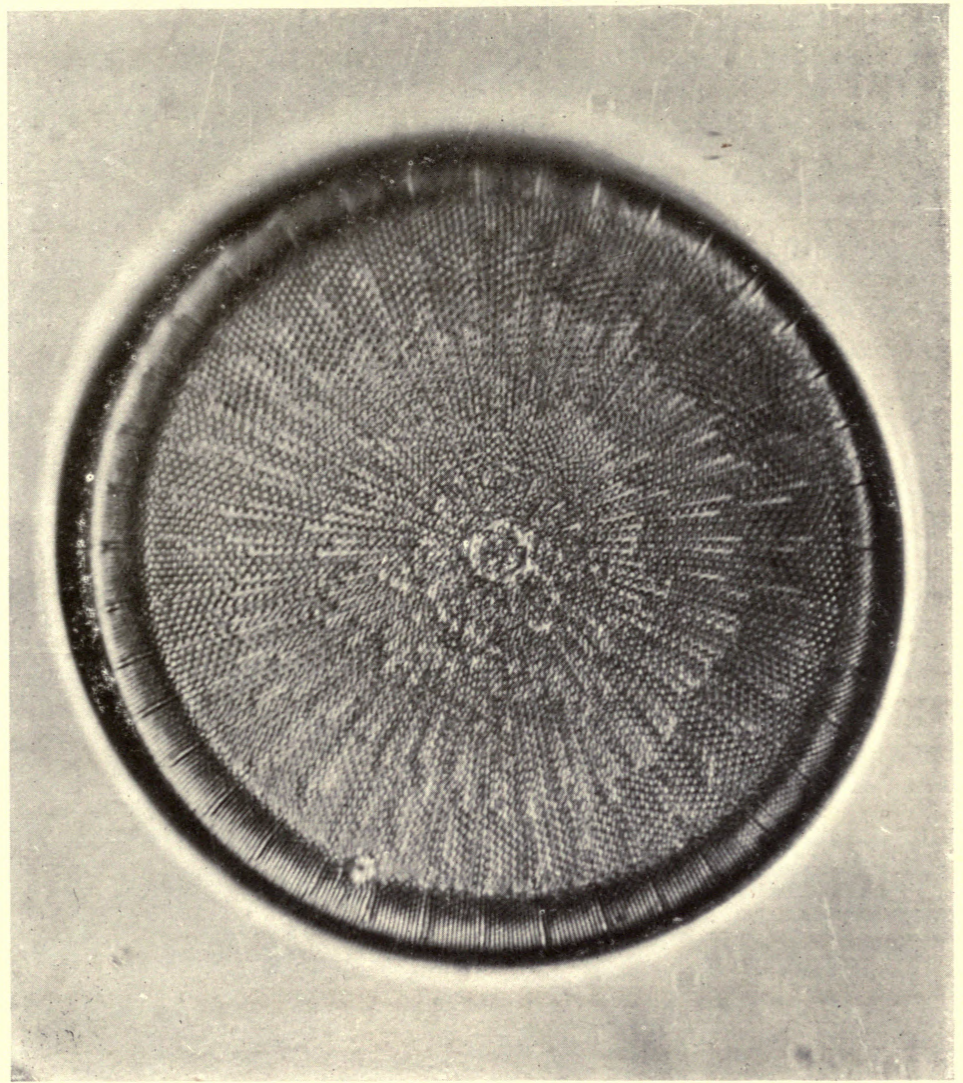

FIG. 6.

DIATOM, ACTINOCYCLUS RALFSII.

$\times 75$ ㅇ.

to face page 32 .

[see paye rio. 



\section{High Possibilities with the Microscope.}

What is the highest magnification obtained with the modern microscope?

This is a question the microscopist is frequently asked.

Two answers can be given to that question.

Those unacquainted with the use of the microscope will bear in mind that students of that instrument never speak of the superficial area of any microscopic amplification; it being understood by them that dimensions are always to be expressed in diameters only.

Those who, at the Royal Society's recent Conversazione, were privileged to see the "High Power Microscopy," by Mr. J. W. Gordon, must have realised that microscopy had made a decided step forward by that gentleman's invention.

The answer, or one of the answers to the above question, will be apparent from a brief consideration of Mr. Gordon's ingenious methods.

He had two microscopes. In the field of 
view of one he placed an opalescent screen which he kept oscillating to serve as a secondary source of radiation and to expand the transmitted wave front, causing it to fill the aperture of the second microscope. This latter instrument gave a further magnification of 100 diameters. The oscillation of the ground glass or opalescent screen removed the imperfections of excessive magnification and rendered invisible its own grain. A diatom (Pleurosigma angulatum) was exhibited, and showed an amplification of 10,000 diameters. Its markings were clearly defined.

When we remember that this particular diatom is practically invisible to unassisted eyesight, and that its highest amplification in Dr. Dallinger's edition of Carpenter's Microscope and its Revelations is 4,300 diameters, we cannot but realise that a very distinct advance has been made.

To suggest a second answer to the question propounded, I must refer to diffraction gratings or microscopic rulings.

Lines have been ruled by extremely deli- 
cate instruments on speculum metal up to 14,000 lines, and even more, per inch, but so far Mr. Grayson has far surpassed all other records in microscopic rulings. His plates contain 120,000 lines per inch.

Mr. E. M. Nelson, one of the greatest authorities on microscopic research, tells us his experience in resolving those lines; it need hardly be said that such fine work requires uncommonly good microscopic powers and excellent illumination for their resolution.

Mr. Nelson found that he could resolve strongly the 120,000 th band with a $\frac{1}{8}$ th inch oil immersion lens; he also resolved the same lines with a cheap $\frac{1}{10}$ th inch oil immersion.

The 90,000th band he resolved with the $\frac{1}{6}$ th inch, and also with a Powell and Lealand's best $\frac{1}{4}$ inch; and the 60,000th band with a Zeiss $\frac{1}{2}$ inch. (Royal Micros. Journal, 1904).

The rulings are mounted in realgar, and are more difficult to resolve than diatoms of equal fineness.

This being Mr. E. M. Nelson's experience, the statement made in the latest works on 
optics used in the Universities that 'the theoretical limit of microscopical vision is the $\frac{1}{90000}$ th of an inch' is hardly correct, inasmuch as 120,000 lines, or $\frac{1}{3}$ rd more, can actually (not theoretically) be seen showing up strongly with a $\frac{1}{8}$ th inch oil immersion, which is by no means a very high-power objective nowadays.

Although the high amplification of 1,000 diameters is not an extensive limit to the powers of the microscope, yet, beyond this, the objectives must be higher than the $\frac{1}{12}$ th inch, and the eye-pieces of the highest power.

Only a few, who may be looked upon as specialists in microscopy, ever exceed this range of magnification.

Several of these illustrations are from negatives of much higher amplification than 1,000 diameters, but in these cases the camera has augmented the work of the microscope. 


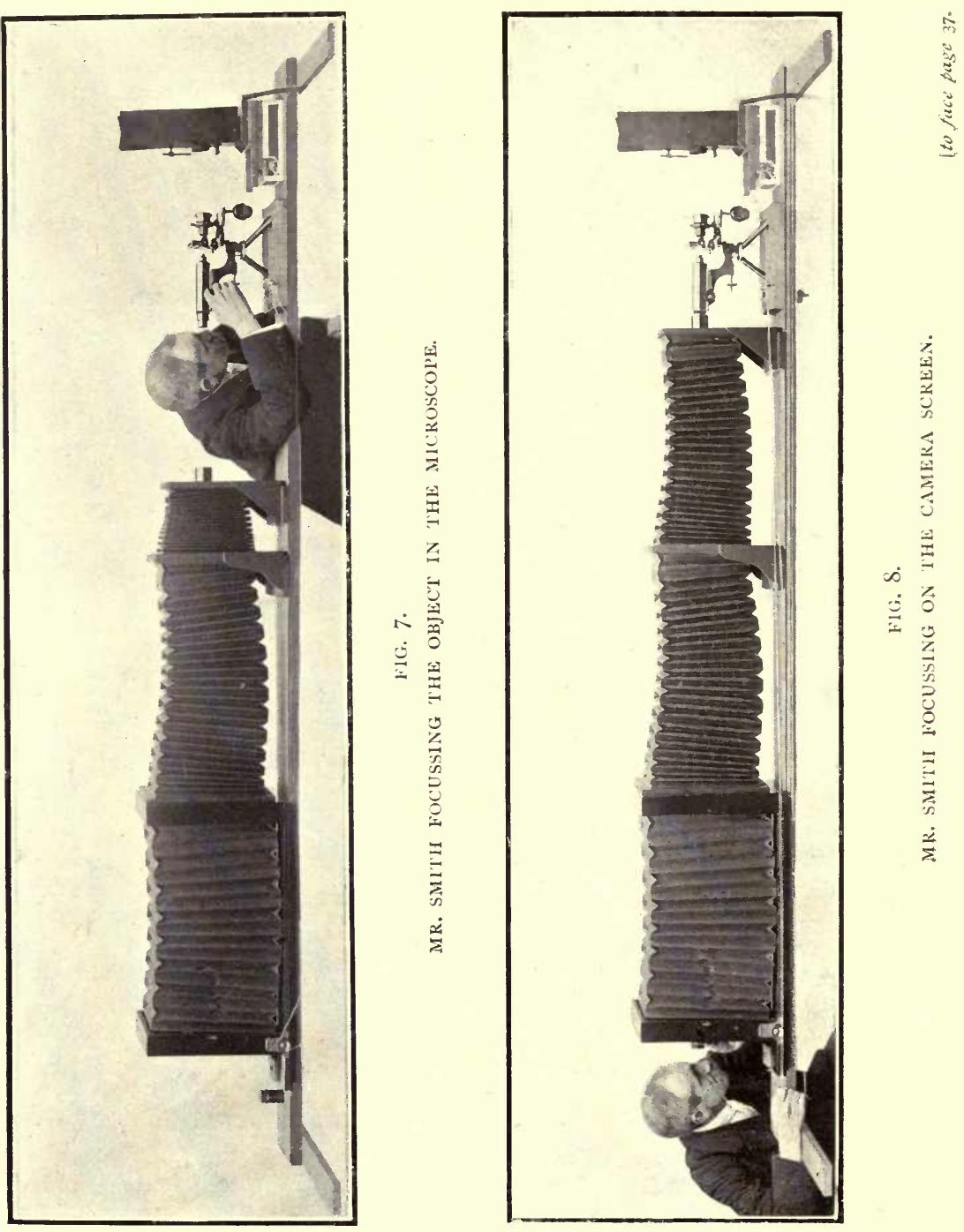


\section{CHAPTER II}

\section{PRACTICAL HINTS ON PHOTO- MICROGRAPHY *}

A MICROSCOPE slide for photographic purposes should be perfect and the object typical. An imperfect slide is difficult to photograph and never looks well.

The starting point is to place the slide in the microscope and see exactly what is required to be photographed; the microscope can then be placed horizontally and the lighting arranged so that the effect seen when viewed through the tube is exactly what is required to appear in the photograph. (Fig. 7).

It is well and convenient to have the camera and microscope adapted to a rigid and perfectly straight base and in such a manner

* This chapter is contributed by Arthur E. Smith. 
that the camera may be easily lengthened or shortened.

If the camera can be placed on runners or in a sliding groove to allow of its being moved aside while the object is being illuminated and adjusted in the microscope it will be a decided advantage.

This done, the front of the camera should be brought up to the eye-piece end of the microscope. The point of junction must be made light-tight, and the whole fixed so that the two instruments are, for the time being, practically one.

There will now be some sort of an image on the ground glass, and a slight adjustment of the focus ought to make that image sharp.

A long rod or a cord can be placed along the length of the camera and adapted to work the adjustment-screw of the microscope in either direction, as shown in the illustration (Fig. 8).

For the low and medium powers a focussing glass can be used with great advantage, but with very high powers when the image is dim the focussing can be better 
done with the naked eye or with a very lowpower magnifier.

The magnification should be carefully ascertained and marked on each negative. For lower powers this is easily found by using a thin piece of metal with, say, a $\frac{1}{8}$ th inch hole bored through it. When the photograph is taken and the microscope slide removed, the piece of metal is placed on the stage of the microscope. The image of the hole falls on the ground glass screen, and its amplification can be easily ascertained.

With high powers a micrometer must be used. This is a glass slide with lines ruled on it, the $\frac{1}{100}$ th and $\frac{1}{1000}$ th of an inch apart. This is focussed as in the former instance on the ground glass screen. If the lines of the $\frac{1}{100}$ th divisions appear 2 inches apart, then its magnification is 200 diameters. If the lines of the $\frac{1}{1000}$ th division appear, say, 3 inches apart, the magnification will be 3,000 diameters.

A convenient method is to have the support of the camera graduated in inches and parts of an inch. In this way the amplification 
would be known without measuring each time.

The focussing cloth may be used in the usual way for low powers, but is almost out of the question for high powers. With very high powers the best way is to have a special perfectly dark room for the camera.

\section{The Dexeloper, Plates, \&c.}

A convenient developer is that originally issued as the Ilford Universal Developer, but somewhat modified for ease of mixing.

Very weak images to low magnifications can advantageously be produced on process plates, as these give great contrast.

The higher magnifications must be done on quick plates.

The exposures vary from two seconds to about two hours, or even longer. These long exposures of the higher powers are very difficult to keep free from vibration. The slightest shake, as a matter of course, spoils the negative. A good condenser will materially shorten the exposure. 
Isochromatic plates are generally most useful, as with the object stained purple, which is usually the case, a yellow screen has to be used between the light and the object to make the purple come out much stronger. At the same time it increases the exposure four to six times, according to the density of the yellow glass screen. The yellow screen can also be used to reduce contrast where part of the image is yellow. Take as an example, a transparent insect containing yellow eggs; in the ordinary way of photographing, the eggs would come out dark, but with a yellow screen the eggs would come out full of detail.

The illustrations have been, for the most part, taken on 12 by 10 plates. For this size a comparatively long camera had to be used.

The objectives can be used without any eyepieces, or with varying eye-pieces, according to the magnification required.

\section{Approximate Exposures.}

If an object has a normal exposure, say, of 10 seconds when amplified to 20 diameters, 
it will require an exposure of 1,000 seconds (just over 16 minutes), if the amplification is to be 200 diameters.

$$
\begin{aligned}
& \text { Thus } \begin{aligned}
\frac{200}{20}= & 10 \\
10^{2}= & 100 \\
& 100 \times 10 \text { secs. }= \\
& =1,000 \text { secs. } \\
& =16 \text { mins. }+
\end{aligned}
\end{aligned}
$$

If the exposure of an object be $1 \frac{1}{2}$ mins. when the amplification is 45 diameters, the exposure will be $13 \frac{1}{2}$ mins. if the amplification is to be 135 diameters.

$45^{2}: 135^{2}:: 1 \frac{1}{2}$ mins. to $13 \frac{1}{2}$ mins.

The magnification can be calculated approximately when no eye-piece is used, thus :-

With a 1-inch objective and a 40 inches focus the magnification should be 40 diameters.

Or, with a $\frac{1}{6}$ th objective and a 30 inches focus the magnification should be $30 \times 6=180$ diameters.

But as the objectives are not always 
accurately marked this method is not always reliable.

The photographs from which these illustrations have been taken have been done with achromatic objectives.

In no case has any touching-up been resorted to. 


\section{CHAPTER III}

\section{FOSSIL RADIOLARIA (POLYCYSTINA) AND FORAMINIFERA}

\section{Fossil Radiolaria.}

(Polycystina.)

$I^{\mathrm{N}}$ the opinion of a great many microscopists 1 there is no more beautiful object for study than a slide of polycystina from the rocks of Barbados.

People have been tempted to purchase microscopes from having seen, for the first time, a collection of these matchless structures. Wordpainting fails to describe their attractiveness. Photography through the microscope helps to convey a something of their beauty, but the actual specimens must be seen mounted on a 


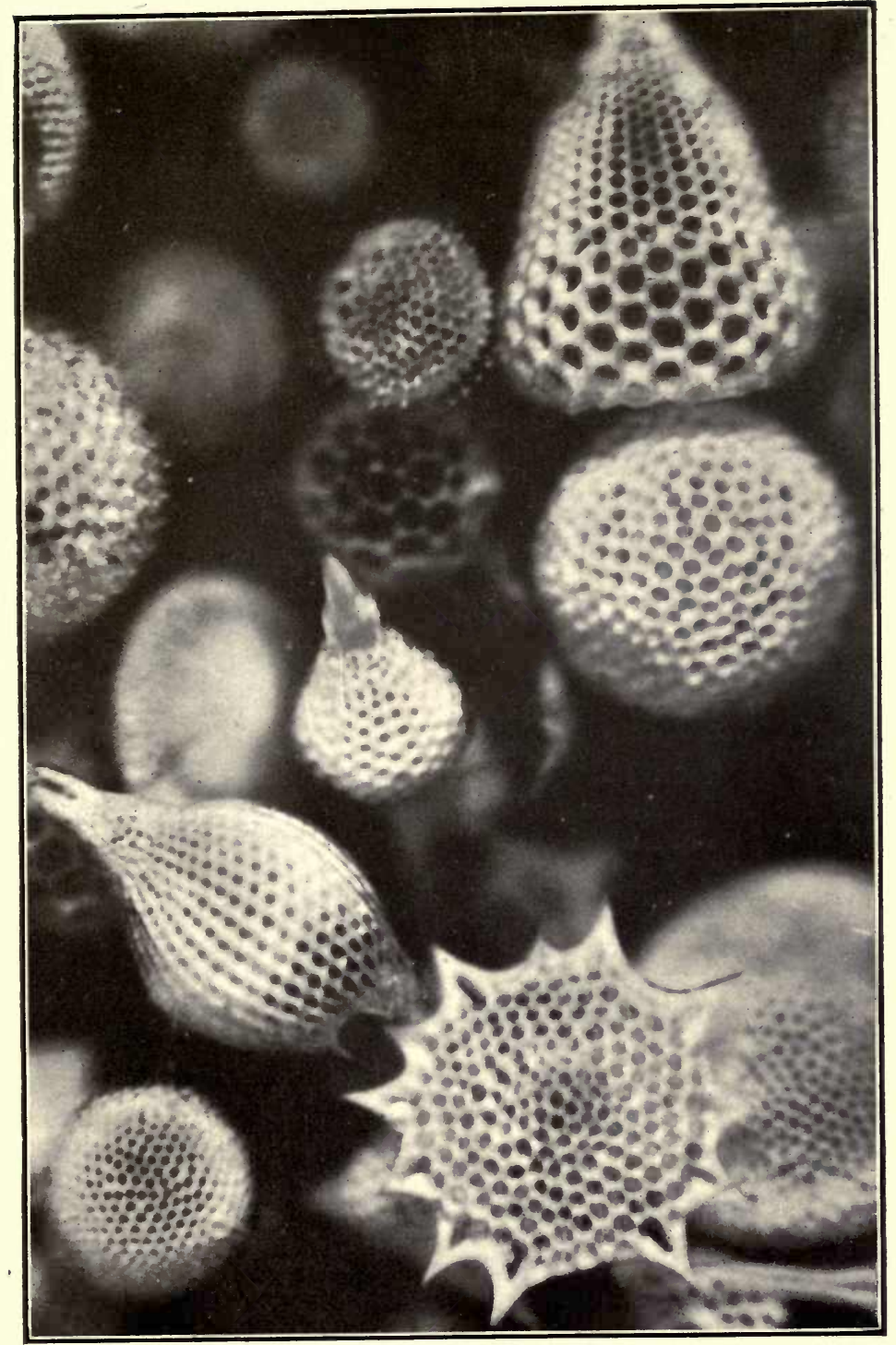

F1G. G.

POLYCYSTINA FROM BARBADOS. 

dark background in order to arouse the enthusiasm they deserve.

To know something of their history and nature we must consider some of the details of structure of living representatives of these homes or skeletons of creatures of long-past ages.

During the 'Challenger' expedition vast numbers of exquisite forms assumed by the skeletons of the Radiolaria were found in the ocean surface dredgings. Some of them consist only of spines radiating from the centre, which, however, are often beautifully sculptured and branched. In one particular form the number of spines is always twenty, and these are all arranged with absolute regularity at definite angles to each other. All this mathematical accuracy in a flinty framework about the hundredth of an inch in diameter!

Some of the creatures appear as spiny balls, one ball inside the other, and fitted together by latticeworks of flint of glassy texture. Ball within ball, they remind one of the Chinese carvings in ivory. 
The protoplasm, or soft body of the tiny organism, surrounds the framework inside and outside. Some of the skeletons take the form of a network with hexagonal apertures.

A framework may be round for a time, and then a second framework may be added below the first with a wide opening at its base, the whole having the outlines of a helmet ornamented at definite points. There is an extraordinary variety of form in the skeletons of Radiolaria. In all cases the fossil forms, as well as their existing representatives, are of microscopic dimensions, and, taken individually, they are scarcely, if at all, visible to unaided sight.

Radiolaria are all marine; most of them live near the surface in tropical seas, and their skeletons sink to the bottom of the ocean, where they are now forming extensive deposits of radiolarian ooze at depths of from 2,000 to 4,000 fathoms.

Passing now to the fossil forms, the flinty skeletons seem to retain most of their beauty, even though embedded for untold centuries in 
the siliceous marls and shales of the Tertiary age which occur in Barbados, Cuba, Trinidad, Richmond in Virginia, Sicily, and the Nicobar Islands.

The Radiolaria in these deposits retain the glassy silica of their shells, and for the most part they are in as perfect condition as recent forms, and many are of the same species as those now living.

Recent researches in geology show that Radiolaria may be of great geological age, and that they occur in siliceous rocks of all formations from the Cambrian upwards.

There need be no difficulty in obtaining specimens for examination, as will be seen from a subjoined list of rocks in which they are to be found in abundance.

Localities and rocks in which Radiolaria have recently been found:-

Cambrian strata in Thuringia.

Reddish rocks of Ordovician age in the South of Scotland.

Shales in Languedoc and Saxony.

Jaspers of Devonian age in Siberia.

Kieselshiefer of Hesse and Nassau.

Lower Culm or Carboniferous strata of Devon and Cornwall, 
Jaspers and Whetstones in the Hartz and the Ural Mountains.

Triassic rocks of Hungary.

Liassic rocks of Hanover and the Tyrol.

Jurassic rocks of Italy and Hungary.

Coast ranges of South California.

Cretaceous rocks of Westphalia and Manitoba.

From this extensive list it will be seen that the Radiolaria, with all their beauty of form, are as old as most forms of life, and that their history runs parallel with that of most of the massive land and marine creatures of several successive geological epochs.

They form the chief constituent in the composition of the jasper, chert, and hornstone of vast extent in the Mesozoic and Palæozoic rocks. In fact these rocks, however intensely hard they may appear, are mainly formed of Radiolarian skeletons. By making thin microscopic sections these organisms may be seen distinctly.

Greater satisfaction will, however, be secured by submitting a sample of Barbadian rock to the following process :-

'Crush the rock and boil it in a strong solu- 
tion of common washing soda until separated into tiny particles. Strain off and keep back the sediment, the object being to get rid of any trace of carbonate of lime and to keep the tiny polycystina shells. These must be washed several times and then put into a testtube with nitric acid and boiled for half an hour to remove any possible appearance of lime. Again they must be removed and repeatedly washed in water to get rid of the nitric acid. They are then ready for mounting, and should be bottled in distilled water until required.' This is Mr. Martin J. Cole's method of mount. ing them, and it cannot be excelled.

When a number of these fossil forms are placed under the microscope, they will be found to be a thing of beauty and a joy for ever.

It is no exaggeration to say that sermons have been preached which have been prompted or suggested by a microscopic view of these matchless and exquisitely beautiful organismspart of Nature's building material. And why not? Nature is the 'other book,' and the more 
both books are thoroughly understood, the more they will be found to harmonise.

I recommend the polycystina to all grades of thinkers, to scholars of every school of research, to divines, to philosophers, to teachers of youth, to leaders of thought, with the full confidence that the study of these almost invisible relics of life will impress their minds with the grandeur of Nature, the marvels of geology, the possibilities and the potentialities of mere specks of flint. And their influence is not likely to end even there.

With regard to the first illustration of Polycystina (Fig. 1, frontispiece), the original photo-micrograph had an amplitude of 40 diameters. The exposure was three minutes in sunshine. The second illustration (Fig. 9) is from a photograph of 175 diameters. It was also produced in sunshine, with an exposure of eight minutes.

\section{Foraminifera.}

Under the microscope these shells, whether recent or fossil, are always objects of great 
admiration. Even if they were as large as they are represented in the illustration they would be looked upon as attractive, but we have to try and realise that many of the Foraminifera are no bigger than a pin's head, while many are very much smaller. Beauty where there seems to be no space for its display must always impress us all the more.

In nature the shells of this family play so gigantic a part that the mind seems unable to grasp an idea of the enormous range they cover in the earth's crust, to say nothing of their numerical strength or the amount of individual life they represent.

They form an Order in the Animal Kingdom belonging to the sub-kingdom Protozoa and to the class Rhizopoda.

Most of the foraminifera are microscopic, and their beauty is seen only under the microscope. The tiny animals themselves are marine, gelatinous, and almost structureless, but their shells are composed of carbonate of lime for the most part. 
Their shells range from the simple single cell or chamber to compound or multilocular aggregations of considerable complexity and great attractiveness of form.

In some instances the cells are arranged end to end in a straight line; in others the row of cells is arranged spirally.

In some instances two rows of cells are arranged in alternate spirals. Some have the cells opposing each other around an imaginary axis. There are discoidal shells of intricate and complicated forms, such as the Orbitolites. There are others that in their early days are arranged spirally like small ammonites, but which, when fully grown, have their shells produced at a tangent, so that they look like so many old-fashioned pistols in miniature.

The surfaces of these tiny shells show numerous openings or foraminæ (hence the name), which are the outer orifices of tubules passing through the walls of the shells.

Most of the buildings in Paris are con- 


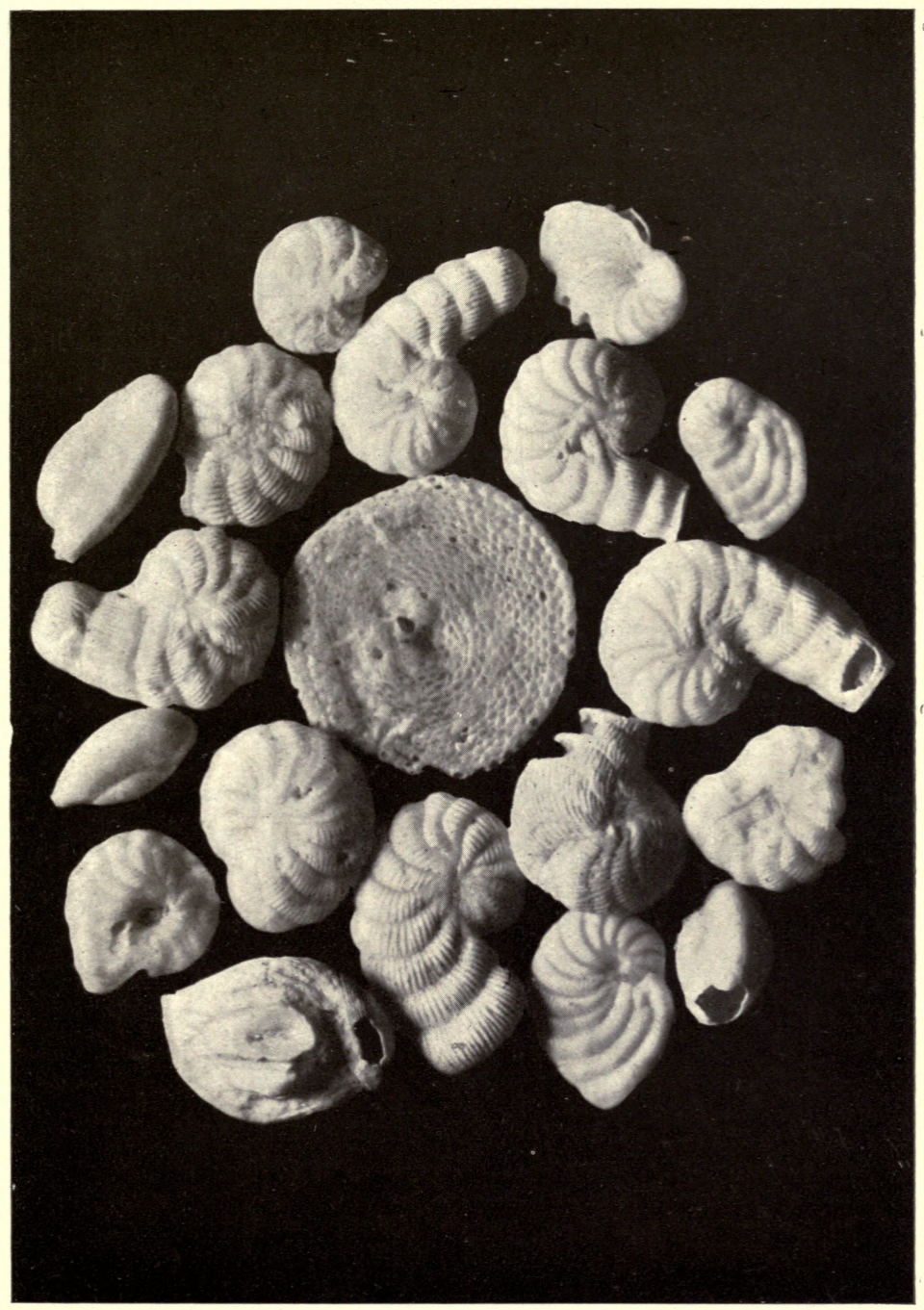

FIG. IO.

FORAMINIFERA. 

structed of a limestone that is composed chiefly of foraminifera shells known as Miliolida.

The rocks comprising the Pyramids of Egypt are almost entirely nummulitic, that is, coin-shaped foraminifera.

If the foraminifera supplied no more material than that required for the construction of these Pyramids they would be considered extensive as products of animal life, but the Pyramids are only a very small portion of the shelly deposit of an ocean floor of earlier ages, now considered as belonging to the Tertiary formation, which extends along the south of Europe and northern Africa into Asia.

The nummulitic limestone alone, which represents only one series of the foraminifera beds, attains to a thickness of several thousand feet and contributes largely to the formation of the Pyrenees, Alps, Apennines, Carpathians, and Himalayas.

The mind is overwhelmed when one tries to think either of the life represented by 
the foraminifera of the past, or the time required for the deposition of such vast hosts of shells in the formation of limestone rocks.

The creatures have left behind the most gigantic results; results, too, that are on the side of the elevating operations of Nature as opposed to the degrading or wearing-down influences, such as the action of water, oxygen, or carbonic acid, \&c.

Other members of the foraminifera, known as fusulina and rotalia, took a large share in building up the limestones of the Old World.

Notwithstanding the minuteness of these shells, most of them are partitioned into several chambers, even if sufficiently small to drop through the eye of a needle.

Plancus counted 6,000 shells in an ounce of sand from the Adriatic. Omitting the sand and weighing the shells only, 280,000 would be required to weigh a single ounce.

One of the best examples of a strand composed almost entirely of foraminiferal shells in the British Islands is that of Dog's Bay on 
the west coast of Ireland. The light shells are blown inland in myriads for a considerable distance, forming drifts and mounds. From this bay alone Chapman obtained 124 species and varieties.

The shells of the foraminifera are easily distinguished by their peculiar shape and texture. They are sometimes white and opaque, glassy or translucent, and often decorated with the finest and most beautiful tracery.

Almost any sheltered bay will supply many varieties for examination. Even a piece of seaweed taken at low tide and placed in a glass vessel of fresh water will be found to contain a good number alive, as they leave the plant for the sides of the vessel.

The shallow-water sands of the Grecian Archipelago and the Levant contain large proportions of foraminifera shells. Any new sponge from these localities will be found to contain quantities, which may be secured by shaking the sponge over a paper or over a vessel of water. 
By carefully washing a specimen of chalk from the top layer in a chalk cliff many varieties may be obtained. The clays also of the Lias and Oolite contain many exquisite representatives of the foraminifera.

The original photograph from which the illustration (Fig. 10) was taken is 40 times the diameter of the tiny fossil marine shells represented. A 2-inch objective was used; the focal distance was 84 inches; and the time of exposure was 15 minutes. 


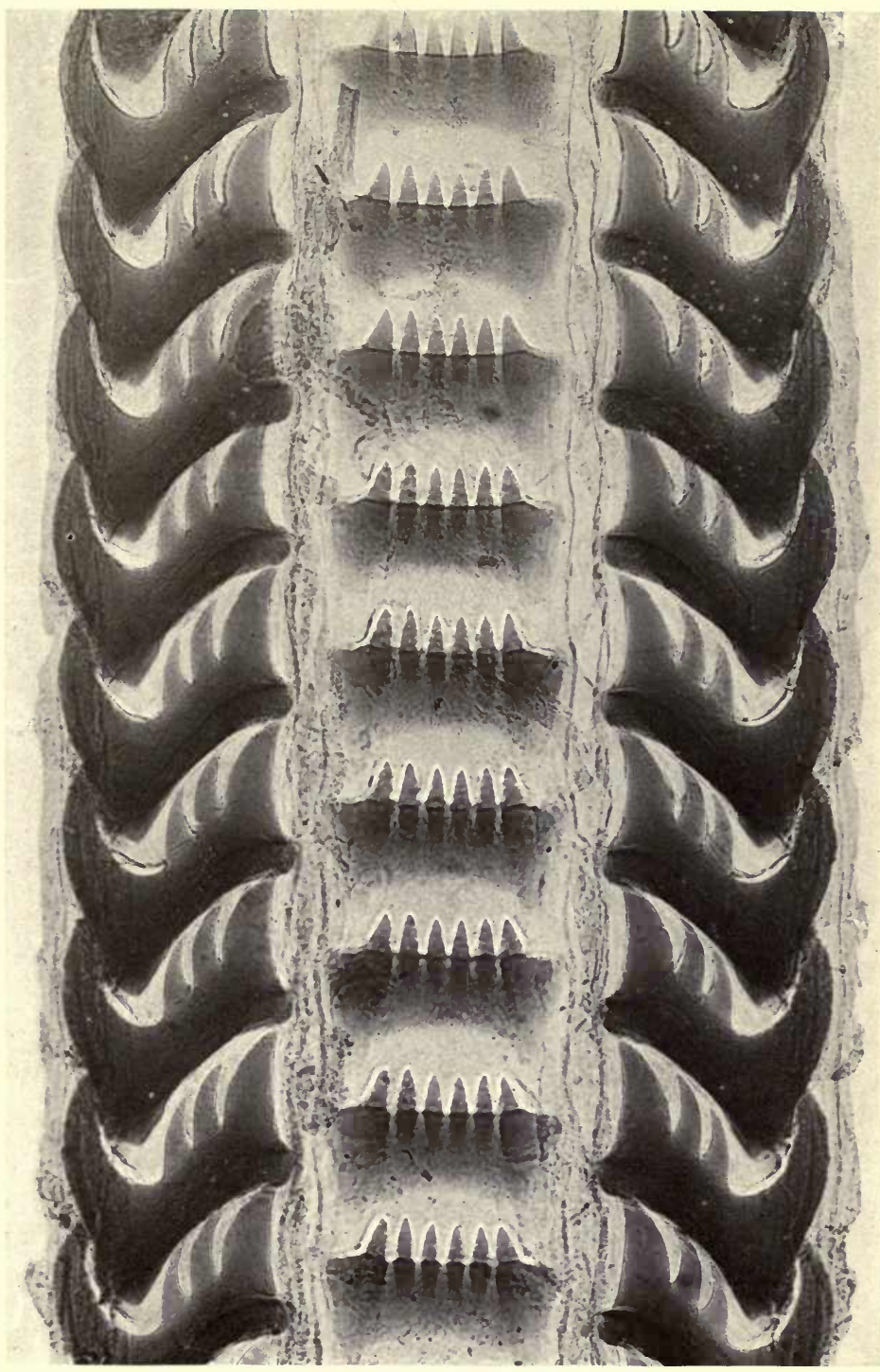

FIG, II

RAI)ULA OF WHELK. 




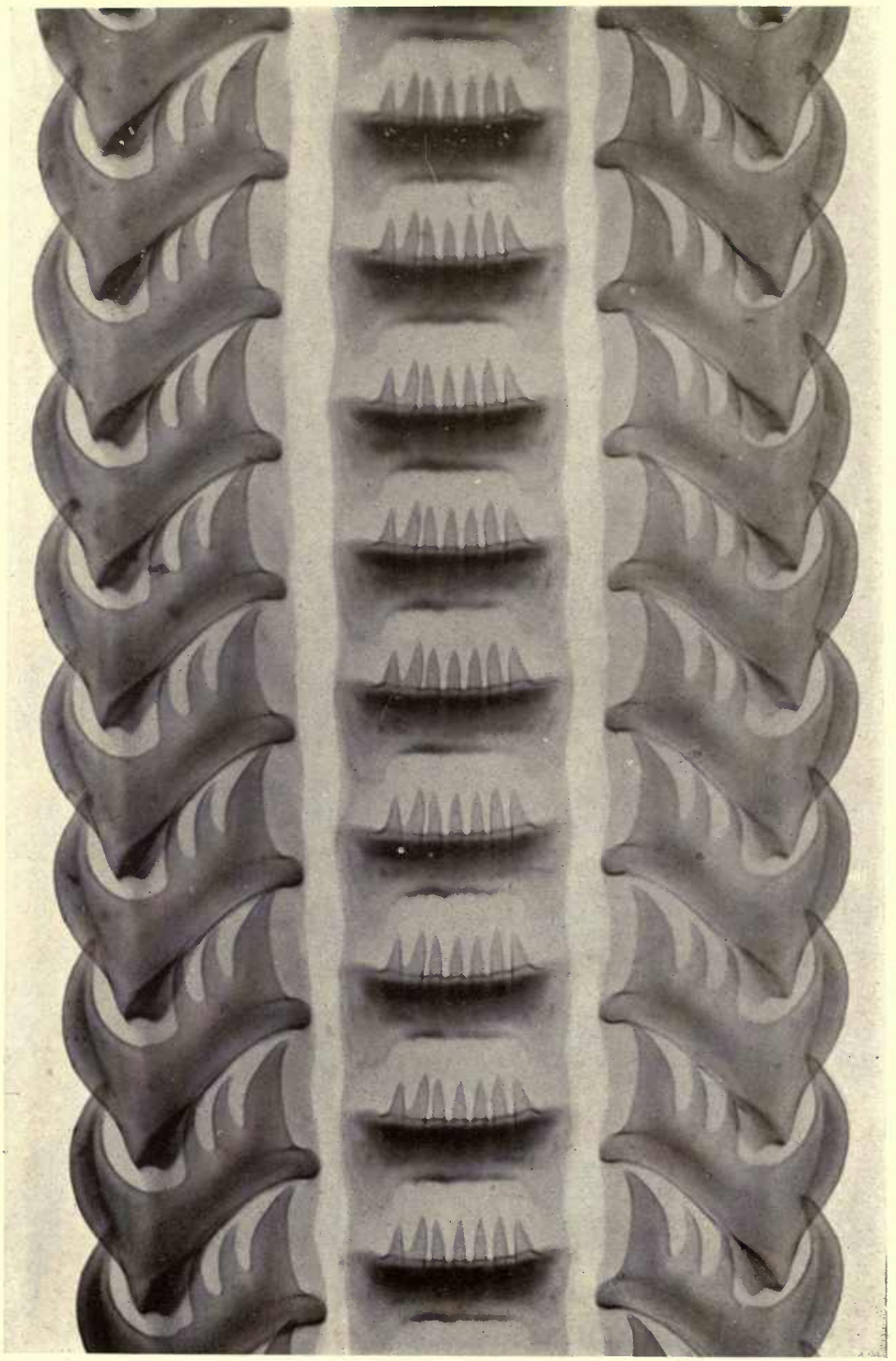

FIG. I 2.

RADULA OF WHELK.

$\times 60$. 


\section{CHAPTER IV}

\section{RADULAE: CIRRI OF BARNACLE AND SPINES OF ECHINI}

\section{Radulæ.}

A $\mathrm{T}$ all times the 'tongues' of the gasterA opoda form very attractive objects for microscopic observation, inasmuch as they display a marvellous arrangement of elegant horny or chitinous teeth. The teeth are arranged in patterns and rows with mathematical precision. By their number, position, and arrangement as well as by their individual shapes they are of importance in characterising the families, genera, \&c.

The 'tongue' in every instance greatly assists the creature either as a rasp for grinding seaweed, or as a hole-borer when used for drilling 
holes in the shells of other creatures for what may be termed sarcophagous purposes. This remarkable organ has a variety of names, and is known as a radula, a spiny tongue, an odontophore, a lingual ribbon, lingual band, \&c. In any case the word 'tongue' is hardly so appropriate as 'radula' or 'odontophore.' In the Gasteropods this apparatus, together with the jaws, completes a marvellous moutharmature admirably adapted for the rasping or trituration of their food before it reaches the œsophagus and stomach.

The bivalves are not provided with radulæ.

With regard to the structure of the radula, in general terms it may be said to consist of a cartilaginous strap which carries a long series of transversely disposed teeth. By means of a perfect arrangement of muscles and cushions the strap works backwards and forwards as though over a pulley, after the manner of a chain-saw. When the food has passed beyond the operation of the jaws it comes within the province of the radula to tear or scratch, not to bite it. The food passes over it and is carded 
small, the effect being, as a writer describes it, very much the same as if 'instead of dragging a harrow over the surface of a field, we were to turn the harrow points upwards and then drag the field over the harrow'!*

The resulting wear and tear of the anterior teeth is continually made good by the incessant development of new teeth formed in a sort of sac in which the hinder end of the strap is lodged.

In addition to this chain-saw-like motion the odontophore has a scraping action, more or less in a circular direction, whereby the shells of other creatures are gradually bored.

If the radula of a limpet or whelk freshly extracted be drawn across the hand, the teeth can be plainly felt.

Now as to the disposition of the teeth on the radula. The arrangement as well as the number of teeth vary in the different representatives of the Gasteropoda. The teeth are almost invariably disposed in a kind of pattern like the longitudinal rows of colour in a piece of ribbon (for the teeth are beautifully coloured, even apart * Cambridge Natural History. 
from a polariscopic view), down the centre of which runs a narrow stripe, and every band of colour on one side is repeated in the same relative position on the other side. The middle teeth are known as the 'rachidian,' the teeth next adjacent on each side are known as 'laterals,' while the outermost are styled ' uncini' or ' marginals.'

In the radula of the common whelk (Buccinum undatum) there are about two hundred and fifty teeth. In that of the common periwinkle about three thousand five hundred. In the Ear Shell (Haliotis tuberculatus) the odontophore is well developed. The teeth on the median line are flattened out, recurved and obtuse, those on the inner or first rows of laterals are trapezoidal, while those known as the ' uncini' are generally hooked. The odontophore of this creature seems to be most complicated, the teeth vary in shape so much. In fact, those of the inner laterals may be compared to those of the shark, but are extremely minute. Instead of one row each, the outer laterals contain several rows of teeth. 



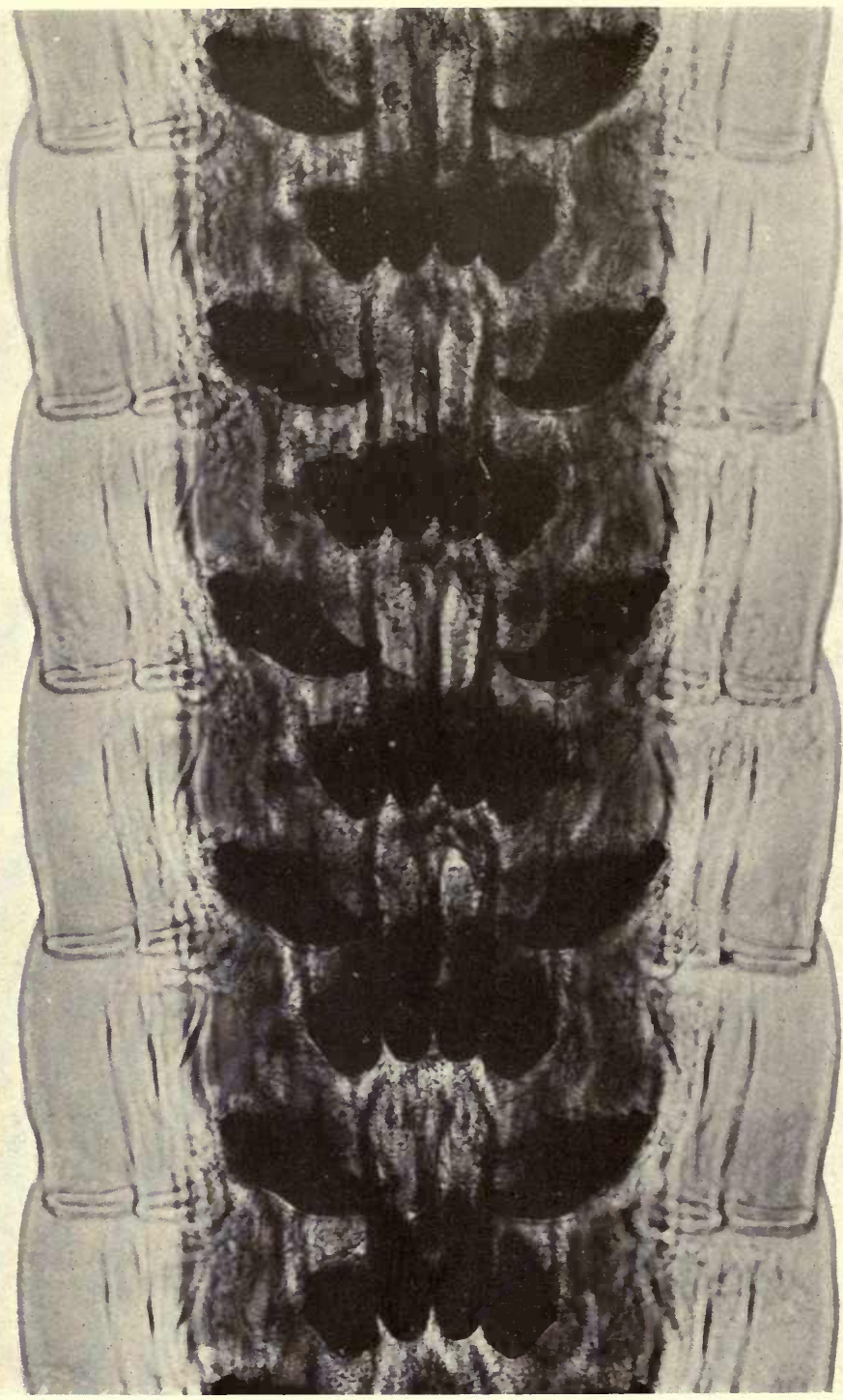

FIG. I3.

RAIUUA OF LIMPET.

$\times 100$. 
This creature's lingual band is divided into five different areas, distinguishable by the different characters of the teeth they bear.

The odontophore of the common whelk has only three plates in each row, one carrying the small central teeth and the two lateral ones bearing the larger teeth. It is one of the most fascinating for observational purposes.

In the illustrations the odontophores of two different whelks are shown, and it will be noticed that there is a difference between them, a difference that in the actual specimen could not be detected but by the microscope. In the central area of Fig. 11 there are six tiny teeth in each horizontal row, but in Fig. 12 there are seven. Whether an abnormal condition is here presented to us, or whether the extra tooth per row in the median area is a question of the creatures' comparative ages, we must leave to the opinion of the marine biologists.

The radula of the English limpet (Patella vulgata) is longer than the shell itself, and is 
provided with 1,920 glassy hooks in 160 rows of 12 teeth each.

But it is among the land representatives of the Gasteropoda that we meet with the most astonishing instances of large numbers of teeth.

Helix Pomatia has 21,000 arranged in symmetrical order on its lingual band. The large garden slug (Limax maximus) possesses 26,000. A single tooth measures only the 10,000th of an inch! These numbers, again, are excelled by the Umbrella mediterranea and the Umbrella indica. They seem to baffle calculation. Possibly 750,000 may be somewhere near the truth.

In the illustrations shown, only small portions of radulæ are taken and amplified to about 100 diameters. Even these show that the number of teeth on each must be very great indeed. When it is remembered that the foregoing numbers refer to a series of forms curiously carved and sculptured, and the total area carrying them in magnificent regularity is only like that of a coiled-up watch-spring, we must 
be filled with admiration at the marvellous creative power lavished upon the organisation of these lowly creatures.

The illustration of the whelk's radula (Fig. 11) is from a negative of 100 diameters; the objective used was the half-inch and the focal length 50 inches.

That represented in Fig. 12 is from a negative of 80 diameters ; the objective was the half-inch and the focal distance was 40 inches.

The radula of the limpet (Fig. 13) is illustrated from a photo-micrograph representing the object amplified to 100 diameters; the objective used was the half-inch and the focal distance was 50 inches.

\section{The Cirri of Barnacle.}

The word 'cirri' is from cirrus, ' a lock of hair.'

Both the chief representatives of the Order Cirripedia, viz., the Lepas or Barnacles, and the Balani or Acorn-shells, possess several pairs, generally six, of the appendages as shown in the illustration. 
The stones and pillars near the jetties at the seaside are often to be found covered with acorn-shells. If a stone so encrusted be placed in a glass vessel of clear sea-water, the delicate plumes may be seen opening out and then retracting. The protruding and retracting processes are accomplished with regularity and order. These form the creature's fishingtackle. They are prehensile and flexible, and consequently are admirably adapted to catch any nutritious particles within their reach.

The sense of touch is exceedingly keen in all parts of these wonderful casting-nets. By the constant movements which the cirri keep up, currents are formed which bring foodparticles within their grasp and on to the mouth. The barnacles in the adult stage fix themselves by a fleshy stalk to any suitable object - shells, drift-wood, ships, \&c. - and develop a peculiar multivalve shell. The acorn-shells attach themselves directly, without any stalk, to stone or wood.

Sometimes after a long voyage the bottoms of ships have to be freed from the barnacles. 



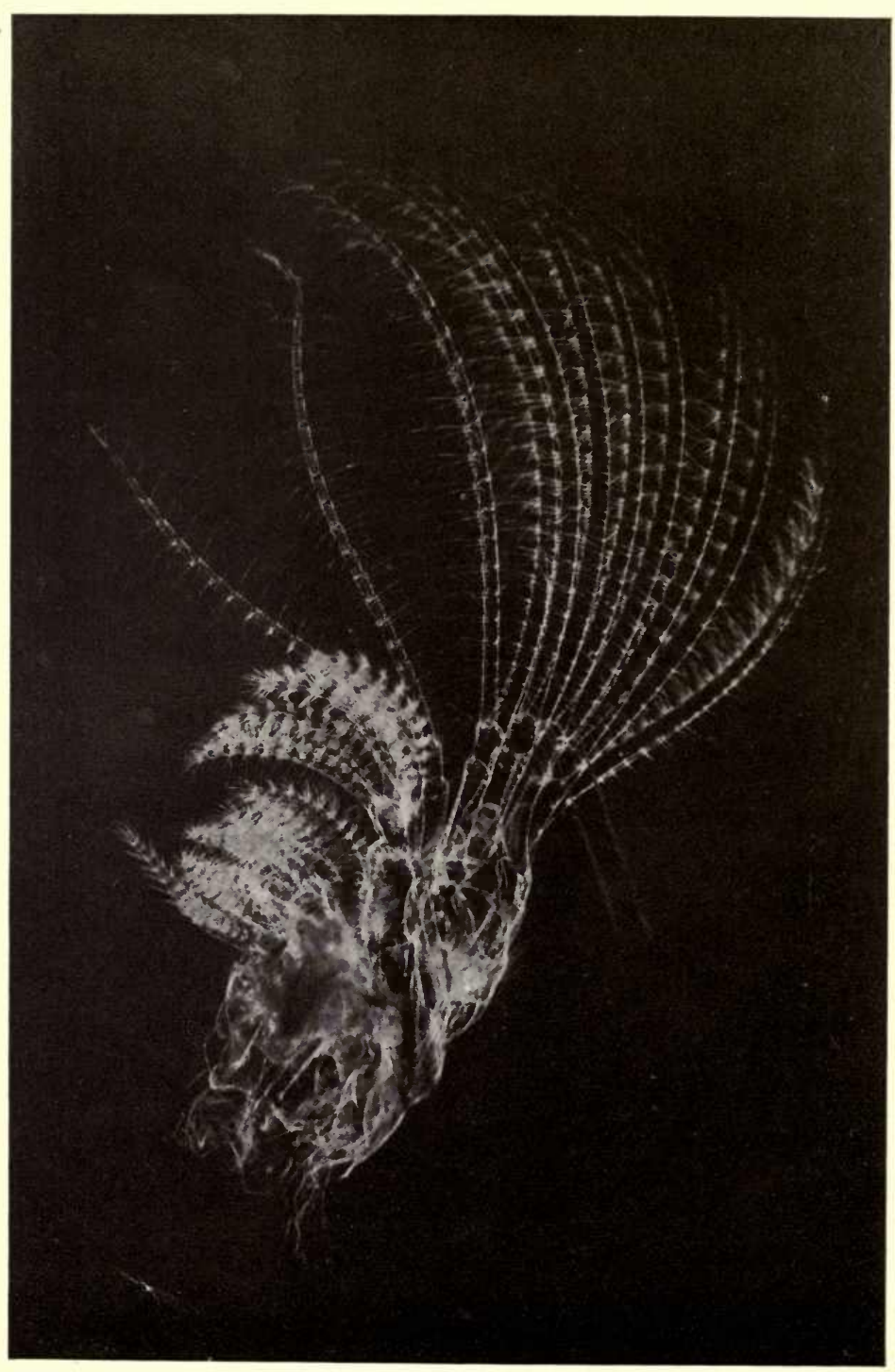

FI(i. I4.

CIRRI OF BARNACLE.

$\times$ I 8 . 
Several tons have been removed from one ship.

Vast quantities of floating timber that would, under ordinary conditions, - seriously interfere with marine commerce is rendered heavier by barnacles and other creatures, and sinks to lower depths. This department of marine life has been more fully dealt with in Nature-Curious and Beautiful.

The illustration (Fig. 14) is from a darkground photo-micrograph, showing the object as if amplified to 36 diameters. The time of exposure was 15 minutes; the objective used was the $1 \frac{1}{2}$ inch, and the focal distance was 52 inches.

\section{Spines of Echini.}

To appreciate the complex structure and the beauty of the spine or spike of a seaurchin, it will be necessary to give a little attention to the plates which make up the shell or 'test,' and also to the tubercles. The shell consists of a number of plates 
fitted together with greater precision than the various parts which make up a coat of mail. The shell adapts itself in the matter of growth to the creature it contains. It is a marvellously strong structure when we consider how very light it is.

Its beauty may be seen by removing all the spines. Sailors, who, generally speaking, have plenty of time on their hands, are adepts at polishing these natural boxes. The work requires great gentleness of handling, but when well done amply rewards the polisher. Previous to the polishing process, but with the spines removed, the surface of the plates will be seen to be covered over with tubercles. Each tubercle consists of a rounded boss, on the centre of which is a small pimple or mamelon.

'These tubercles are of three different sizes, primary, secondary, and miliary. The primary are the largest, and bear the largest spines. Scattered irregularly over the plates are the secondary tubercles, which carry the secondary spines, and between these are numbers of 


\section{STRUCTURE OF SPINES}

smaller elevations, the miliary granules. In addition to the spines, the pedicillariæ are also supported on the top of these tubercles. The spines, like the tubercles, are of three sizes, primary, secondary, and tertiary, and the structure of each is fundamentally the same. Each spine consists of a long shaft marked by longitudinal flutings; the base is hollowed into a cup or condyle, which fits over the pimple of the tubercle. Each spine is furnished with a collar which serves for the attachment of the muscles which fix it to the test.' (A Treatise on Zoology.)

The transverse section, as in the illustration, shows that the spine is made up of a number of solid wedges radiating from a central axis, and separated by bands of porous tissue.

The sections vary in design in the spines of different kinds of sea-urchins. Thin sections of spines make very beautiful objects for the microscope. Patterns for rose windows, for lace, and other forms of ornamental handiwork may be obtained from these 
lovely forms of marine life. The photomicrograph from which the illustration (Fig. 15) was taken shows an amplification of 80 diameters. The time of exposure to gas-light was 10 minutes; the focal distance was 80 inches, and the objective was the one inch. 


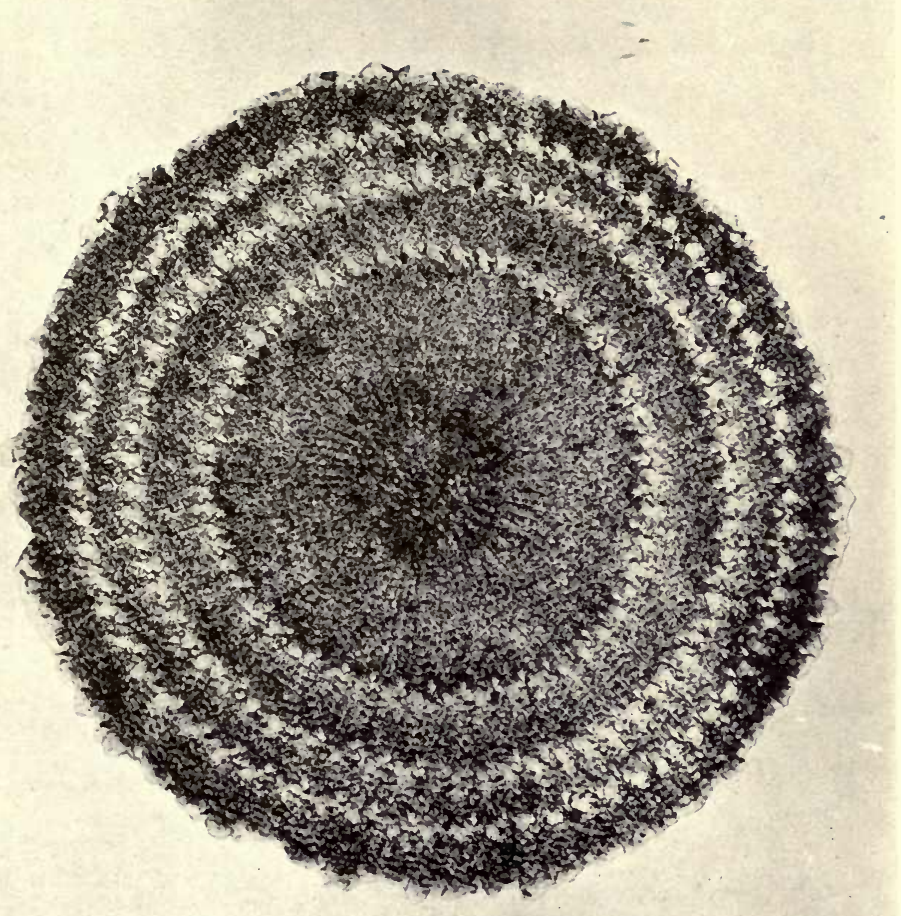

FIG. I 5 .

ECHINUS SPINE SECTION.

$\times 60$. 
. 


\section{CHAPTER V}

\section{INSECT LIFE : PROBOSCIS OF BLOW- FLY AND EGGS OF FLY}

\section{Insect Life.}

$\mathrm{A}^{\mathrm{T}}$ first sight the study of insect life may A not appear very attractive, but there are some insects far more gorgeous in their every-day coats than are many of the Eastern potentates when bedecked with jewels of untold costliness. The microscope brings the insect's gems and scales and facets and plumes within the bounds of our appreciation, but fails to exhaust all their sheen and unsullied brightness.

The various parts of the insect command our highest admiration. The muscular system of insects has always excited the wonder and 
astonishment of the naturalist from whatever point of view he has examined this part of their economy-whether he considered the perfection of their movements, the wonderful minuteness of the parts moved, or the strength, persistence, or velocity of their contractions.

It is true that some insects do a great deal of damage, but there are others that confer additional life, gaiety, and beauty to the landscape. But is it not a wonderful law of Nature that restricts the dimensions of an insect within certain bounds? The ravages committed by them now are trifling and insignificant in comparison with what they could do if they were allowed to attain to a large growth, and still possessed the extraordinary powers with which they are so conspicuously gifted. They could exterminate all that the earth contains of vegetable and animal life!

Rymer Jones tells us that the dragon-fly possesses such indomitable strength of wing that for a day together it will sustain itself 



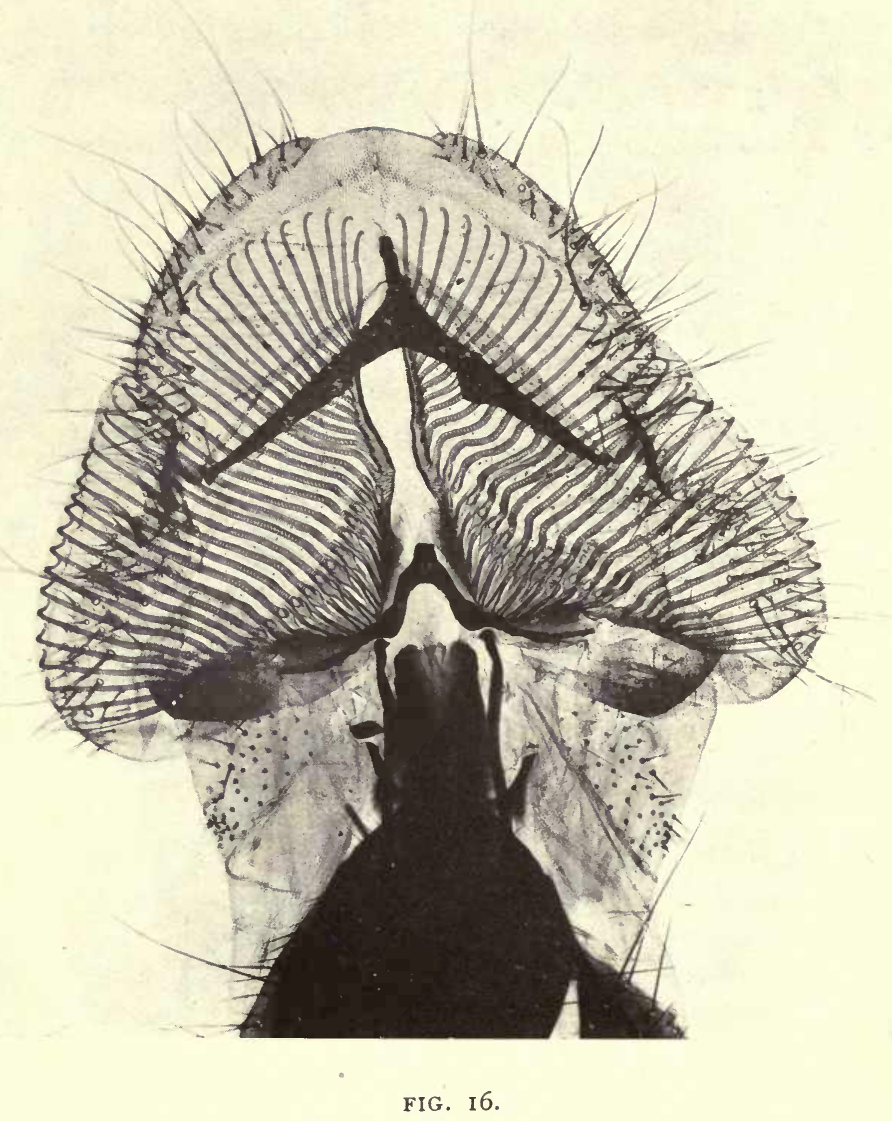

PROBOSCIS OF BLOW-FLY.

$\times 40$.

[to face page $7 \mathrm{x}$. 
in the air, and fly with equal facility and swiftness backwards or forwards, to the right or to the left, without turning. The same writer asks us to suppose for a moment that the law which restricts the dimensions of an insect could be dispensed with in a single species. Suppose a wasp or a stag-beetle dilated to the bulk of a tiger or of an elephant-cased in impenetrable armour, furnished with jaws that would crush the solid trunk of an oak-winged and capable of flight so rapid as to render escape hopeless-what could resist such destroyers? Or how would the world support their ravages? With regard to the house-fly (Musca domestica), Rymer Jones quotes an anonymous writer who has calculated the flight of this insect: ' In ordinary flight it makes with its wings about 600 strokes, which carry it 5 feet, every second; but if alarmed their velocity can be increased six or sevenfold, or to 30 or 35 feet in the same period! In this space of time an Arab steed would clear only 90 feet, which is at the rate of more than a mile a minute. 
Our little fly, in her swiftest flight, will in the same space of time go more than the third of a mile. Now, compare the difference of the size of the two animals (ten millions of the fly would hardly counterpoise one racer), and how wonderful will the velocity of this minute creature appear! Did the fly equal the racehorse in size, and retain its present powers in the ratio of its magnitude, it would traverse the globe with the rapidity of lightning.'

\section{Proboscis of Blow-fly.}

Perhaps no object in insect life has been photographed more frequently, yet it may be said with truthfulness that no microscopist has ever succeeded in either exhausting or in depicting all its detail. The proboscis of the blow-fly or that of the house-fly defies the highest amplification and still reserves to itself many mysteries never seen by the microscopist. It is more complicated than a locomotive, and more highly finished than a costly gold watch. 
It is a contrivance that commands our admiration although we are acquainted with but a few of its actions and uses.

Its exquisite beauty, the minuteness of its thousands of springs, and the finish of its mechanism have led many a man to reflect on his own impotence, and have suggested to his mind something of the sublime skill that must be behind all that we are pleased to call 'Nature.'

The specimen, photographed for the accompanying illustrations, in order to show its histological structure, has been opened out and its lobes spread apart so as to present a thin section for microscopic examination.

Only a portion of the proboscis is shown in either instance. The maxillary palpi and most of the muscular parts are purposely omitted.

A symmetrical system of canals pervades each lobe. These are made up of spring-like structures arranged side by side, which at first remind one of the tracheal system of the waterbeetle Dytiscus ; but on closer examination they are seen to be not spirally arranged, but forming 
open channels, which suggest an arrangement for the passage of fluids.

From the observations of Doctor Anthony these 'pseudo-tracheæ' are suctorial organs, which can take in liquid alike at their extremities and throughout the whole length of the fissures. These fissures may be closed in and thus form complete tubes. This of course implies a voluntary power on the part of the fly which extends to microscopic areas.

The original photo-micrograph from which the illustration (Fig. 16) was taken, shows an amplification of 100 diameters; the time of exposure was 16 minutes; the focal distance was 50 inches, and the objective used was the half-inch.

In the second illustration (Fig. 17), the original amplification is 1,000 diameters; the focal distance was 46 inches; the eye-piece of 5 diameters and the $\frac{1}{6}$ th objective were used.

\section{Eggs of the Fly.}

There are several genera and species of flies that are common in our houses, either habitually 


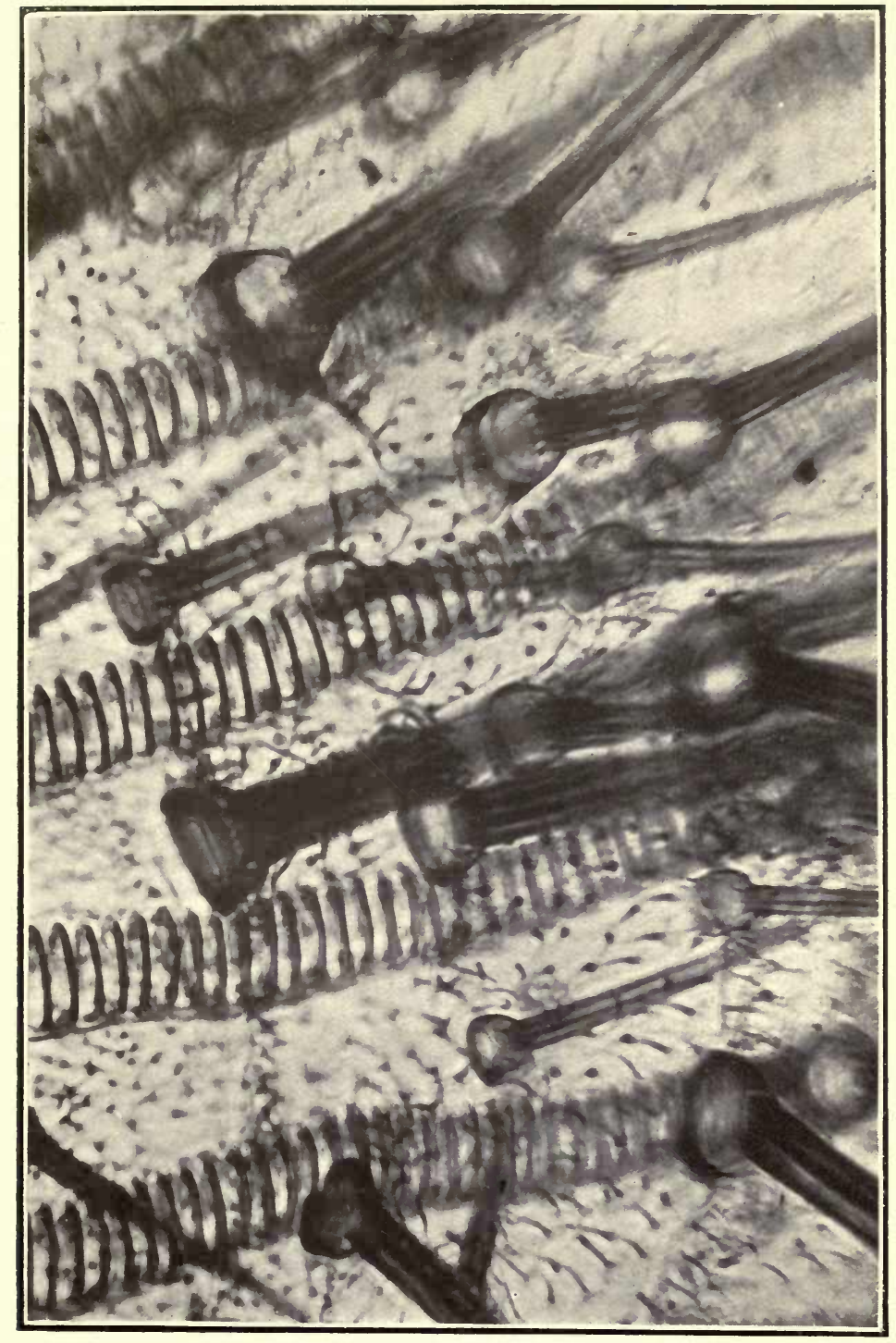

FIG. I7.

PAR'T OF FLY'S PROBOSCIS. 

or casually, and it is by no means easy to distinguish and classify them. If the difficulty be great as regards the insects themselves, it must be greater as regards their eggs.

It is well, therefore, to describe the two principal representatives of the Diptera-the Muscidæ and the Anthomyiidæ.

The Muscidæ contains many of the most abundant flies, including the common house-fly, the blue-bottle or blow-fly, \&c.

The common house-fly (Musca domestica) runs through its life-history in a very short time. It lays about $150 \mathrm{eggs}$, that are very small, on any kind of soft, damp animal or vegetable matter. The larvæ are hatched in a day or two and feed on the surrounding carrion or other putrid refuse; they are fully grown in five or six days, and then, passing through the pupa stage, in another week or so emerge as perfect flies.

It is not to be wondered at that in favourable localities they increase in a short time to such enormous numbers.

It is thought that flies pass the winter in 
the pupal state. The house-fly is widely distributed over the world, and it sometimes occurs in large numbers away from the dwellings of man.

The compound faceted eyes, the proboscis and the complicated feet of the house-fly all form instructive and interesting objects for the microscope. It is now generally believed that the pads on the feet do not support the fly when walking on the ceiling or window-pane by performing the office of suckers, but that they exude a viscid fluid which enables the insect to adhere to smooth surfaces.

The bite of flies that have been feeding on putrid substances is attended with danger. It is well that these flies are not allowed to increase indefinitely. They are subject to the attacks of a white fungus, and possibly to those of a tiny insect, the chelifer.

It is hardly necessary to say that when a fly assumes the perfect state it never grows any larger, so that when we see small flies that appear like the house-fly we must not imagine they are the young of the larger ones. 



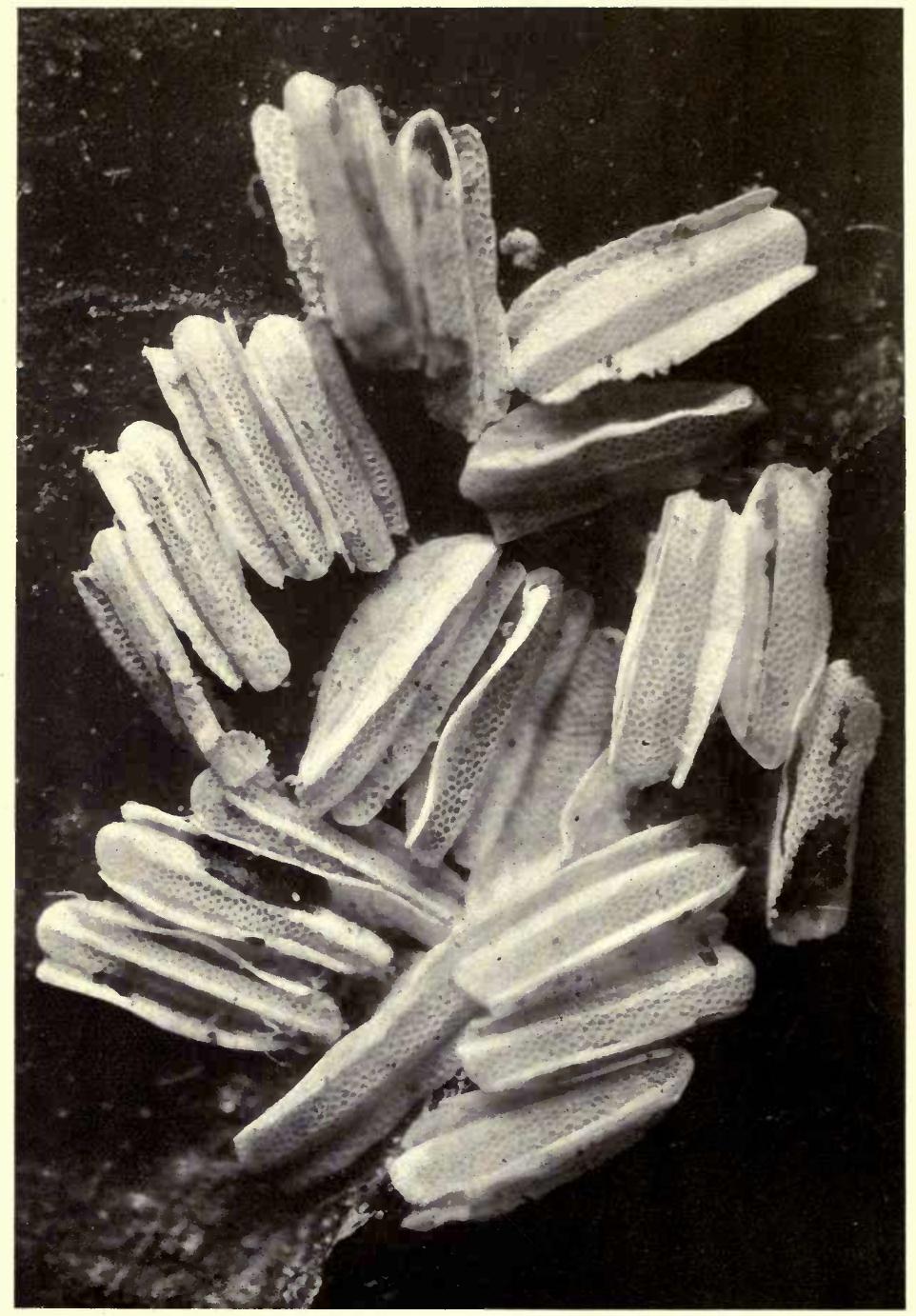

FIG. I8.

EGGS OF HOUSE-FLY.

$\times 42$. 
Linnæus is reported to have said that the progeny of three blow-flies could devour the carcass of an ox as quickly as a lion could. This would have to be under favourable conditions for the multiplication of the insects. ' The other division of the Diptera is the Anthomyiidæ. These are similar in general appearance to the common house-fly. They form a large family of flies, and possibly the most unattractive of the order. The eyes of the male fly are very large and almost touch each other. The main vein posterior to the midale of the wing is continued straight to the margin, and this being only so in the case of the Anthomyiidæ it forms the chief distinguishing feature. The habits of the larva are varied. Many attack vegetables, produce disintegration in them and thus bring about decomposition. Market gardeners are well aware of the destructive powers of the Anthomyiidæ.'*

Flies at best are not desirable visitors in our houses, but it is evident that they act as scavengers on a tremendous scale by devour* Cambridge Natural History. 
ing obnoxious substances which might be productive of zymotic and other diseases. It is also evident that if we were to keep our homes absolutely free from all impurities we should not be so much troubled by these visitors. House-flies will not remain long in a house that has nothing for them to feed on. On referring to the illustration (Fig. 18), some 21 or 22 eggs of the fly will be seen. They are objects of great beauty under the microscope. The original photo-micrograph is one of 72 diameters; the time of exposure was 60 minutes; the focal distance 60 inches, and the objective used the inch. 
CHAPTER VI

BUTTERFLY'S TONGUE, EYE OF DYTISCUS, TONGUE OF HONEY BEE, AND LEG OF HONEY BEE

\section{The Butterfly's Tongue.}

ПHE structure of the proboscis or tongue 1 of the butterfly is inconceivably delicate. Throughout its whole length it consists of two half-tubes, which are convex on the outside surfaces and concave on the inner, so that when the two are brought together they form a complete tube, which is lined with a very smooth membrane. Each half-tube is supposed to be an extended maxilla. In some butterflies the tips possess a great number of delicate papillæ or fringes.

Each maxilla is made of innumerable rings connected and moved by a double layer of 
spiral muscular fibres, that wind in opposite directions round its walls.

When unfolded each of these long filaments is found, under the microscope, to be furnished with a row of exceedingly minute teeth along the margins. It is the locking together of the two rows of teeth of one half-tube to those of the other that establishes the tubular arrangement of the proboscis. They form a complete canal leading to the orifice of the mouth. When not in use the proboscis is coiled up and lodged beneath the head.

The whole apparatus seems to act on pneumatic principles. It is adapted in every way to suction. It pumps up the nectareous juices from the cups of flowers, and is of necessity of considerable length, in order to enable the insect to reach the recesses in which the honeyed store is lodged.

Newport describes the action of the proboscis of the butterfly as follows: 'On alighting on a flower, the insect makes a powerful expiratory effort, by which the air is expelled from the interior of the air-tubes and from 


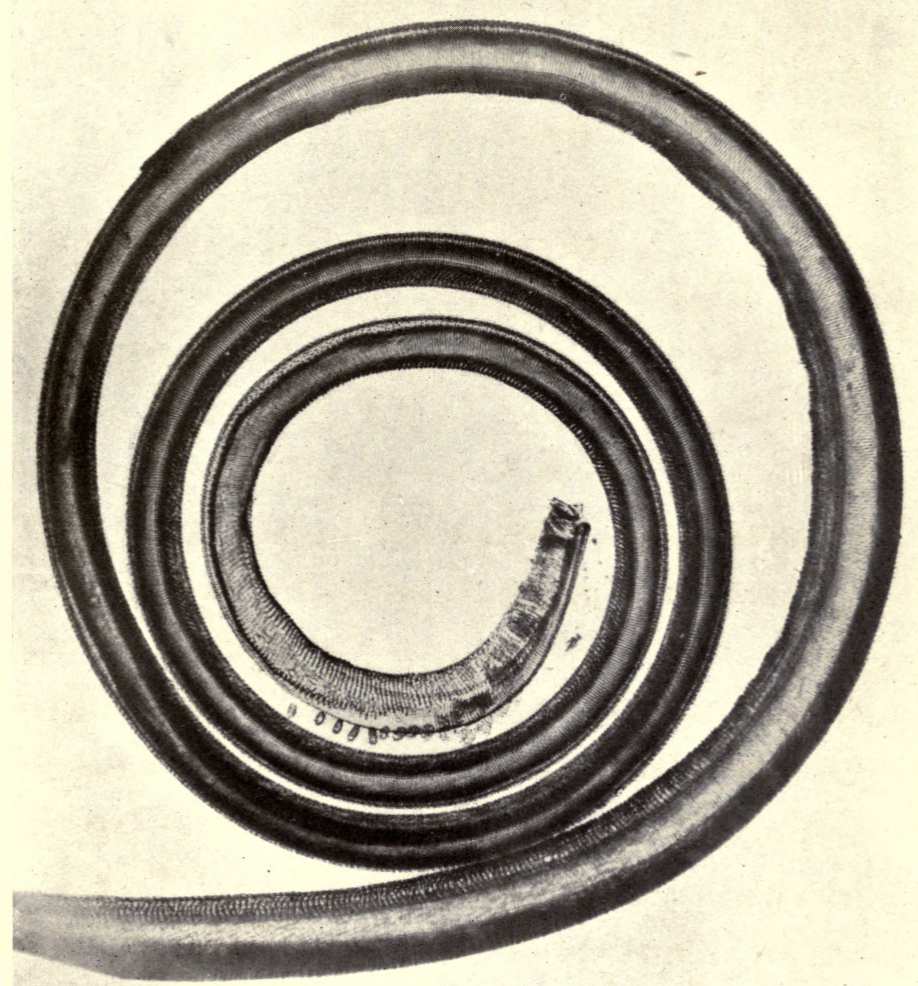

FIG. I9.

BUTTERFLY'S TONGUE.

$\times 5$ o.

to face pirge 8o. 




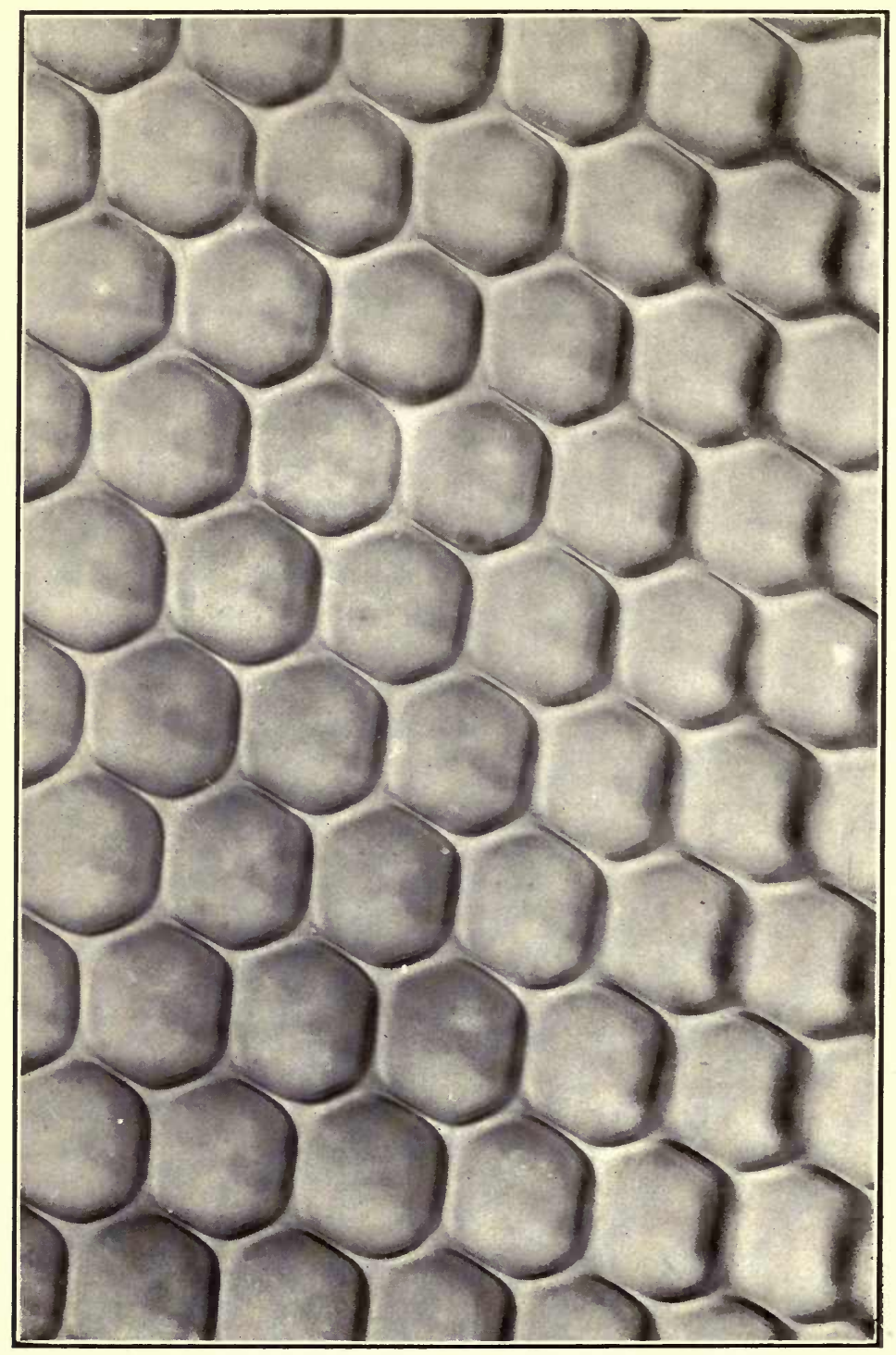

FIG. 20 .

PORTION OF BEETLE'S EYE.

$\times 550$.

[to face page 81. 
those with which they are connected in the head and body; and at the moment of applying its proboscis to the food it makes an inspiratory effort, by which the central canal in the proboscis is dilated, and the food ascends it at the same instant to supply the vacuum produced; and thus it passes into the mouth and stomach; the constant ascent of the fluid being assisted by the action of the muscles of the proboscis, which continues during the whole time that the insect is feeding. By this combined agency of the acts of respiration and the muscles of the proboscis we are enabled to understand the manner in which the humming-bird sphynx extracts in an instant the honey from a flower while hovering over it, without alighting, and which it certainly would be unable to do were the ascent of the fluid entirely dependent upon the action of the muscles of the organ.'

The proboscis of the butterfly when coiled up is about the same size as the fine hairspring of a watch, yet it is endowed with thousands of muscular fibres and other minute 
parts, and its action is based on what we term pneumatic principles. It is a beautiful object, and its study with the microscope ought to fill one with admiration.

The illustration (Fig. 19) shows only part of the butterfly's proboscis coiled up. It is reduced from a photo-micrograph of 130 diameters; the focal distance was 66 inches, and the eye-piece of 5 diameters with the halfinch objective was used.

\section{Eye of Dytiscus.}

Only a very small portion of the very beautiful eye of Dytiscus marginalis is shown in the illustration (Rymer Jones and other eminent naturalists have called this creature Dyticus). The number of ocelli on the eyes of insects is remarkably great. The two eyes of the house-fly contain 4,000 ocelli; those of the dragon-fly, 24,000; those in the Mordella beetle 25,088; the eyes of the butterfly contain about 17,000 .

The dytiscus is a true water-beetle, and is 



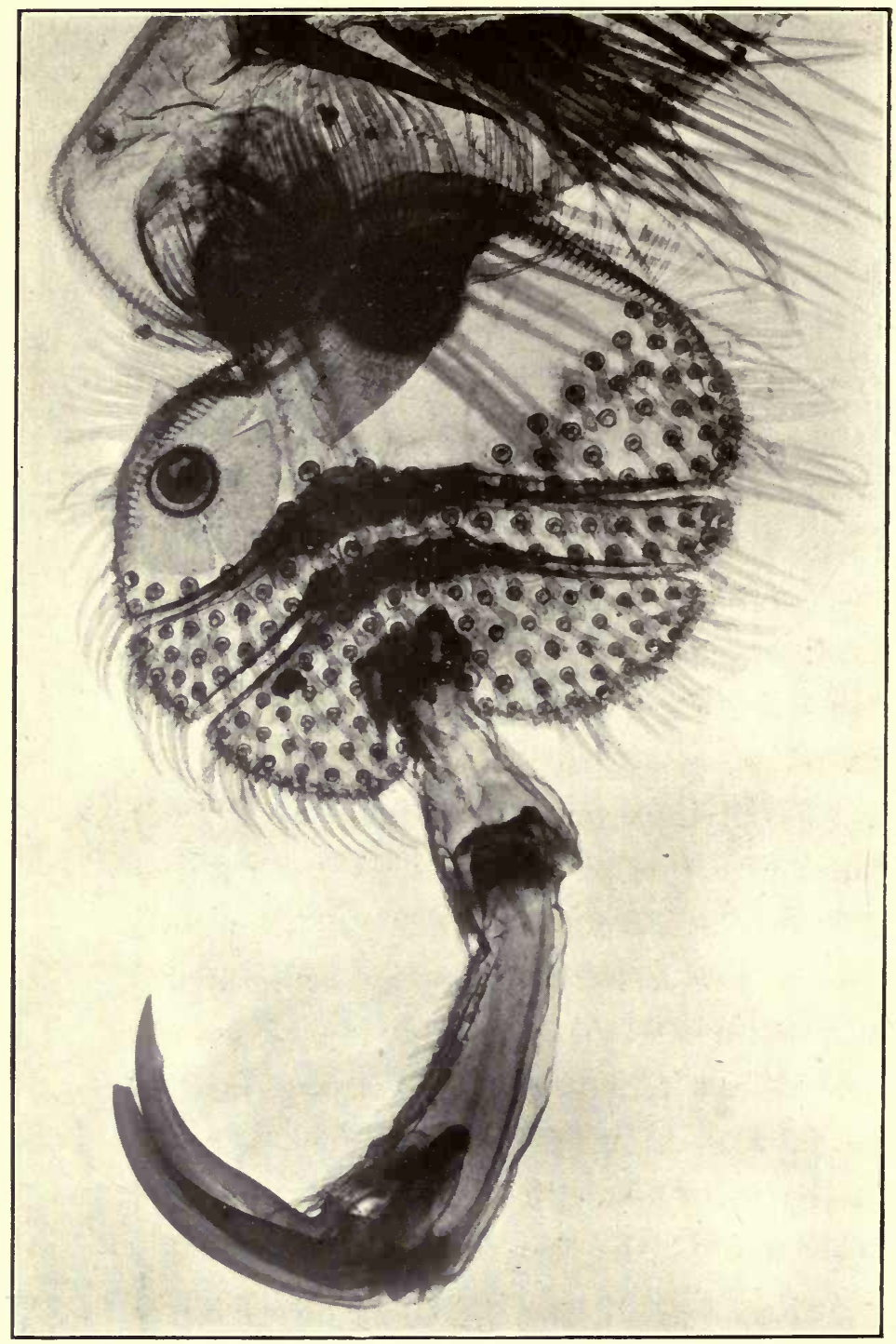

FIG, 2 I.

FOOT OF WATER BEETLE, DYTISCUS MARGINALIS.

$\times 25$. 


\section{LEGS AND WINGS OF DYTISCUS 83}

remarkable inasmuch as in either its larval or its mature condition it can exist in water. There are reasons, however, for supposing that these creatures are modified terrestrial insects. A peculiar feature of their history is that they thrive better in the cooler waters of the earth. Lapland is one of the parts of Europe richest in Dytiscidæ. About 1,800 species are known. Although both larvæ and imagos are perfectly at home in the water, they must come up to the surface to get air.

The hind pair of legs is the chief means of locomotion. These swimming legs are deserving of admiration on account of their mechanical perfection.

The wing-cases so fit the body that the air carried down by them under the water is held, as it were, in an air-tight compartment, and is distributed through the spiracles to the tracheal system. When the dytiscus feels the necessity for fresh air, it exposes the tip of its body exactly at the level of the water. Respiration is effected by this means as well as by the store of air carried down under the wing-cases. 
The eye of Dytiscus marginalis is always considered a beautiful object for the microscope. The face of a watch and portraits of the late Queen have frequently been photographed through the facets or ocelli of this beetle's eye. A small portion of the eye is best for this purpose, because it is easier to flatten out a tiny area than the whole cupshaped exterior.

Claus sums up particulars of the creature in the following words: 'Swimming-beetles, with filiform ten- or eleven-jointed antennæ and broad swimming-legs beset with setæ; the hind legs project back and are especially adapted for swimming by the possession of a close covering of swimming hairs.'

The illustration (Fig. 20) is taken from a photo-micrograph of 550 diameters; the time of exposure was 10 minutes; the focal length was 20 inches; the objective was the $\frac{1}{6}$ th, and an eye-piece of 5 diameters was used.

The illustration (Fig. 21) is from a negative of 32 diameters. 


\section{Tongue of Honey Bee.}

The structure of the tongue of Apis mellifica is remarkably complex, and yet comprised within very small dimensions. The two outer semi-sheaths are greatly extended maxillæ, which form a tube-sheath, when closed, for the protection of the delicate lingula or tongue proper, as well as the two labial palpi. These latter are also greatly developed, and coming together form an inner sheath for the tongue. The tongue itself, being a most delicate organ, is well protected by double sheaths.

When it is necessary to put the tongue into operation the maxillæ pierce the flower and open out, enlarging the opening made to make way for the tongue to penetrate the flower-depths for their juices. The tongue, when in use, is capable of protrusion far beyond the limits of its double sheaths. It is a veritable proboscis covered with hairs. When the whole apparatus is closed, the tongue is retracted into a small space. 
It was the opinion of Dr. Jabez Hogg that the tongue is cylindrical, and used after the manner of that of the butterfly. But this does not seem to be borne out in the illustration. In the original photo-micrograph we have the whole apparatus shown 10 inches long. Of this length the tongue proper is 5 inches, and therefore of sufficient size for close observation. It appears to be a solid body with annular muscular bands, capable of extension and contraction.

The juices of the flowers are conveyed along the tongue to the receptacle at the base of the labial palpi. Each of these labial palpi is terminated by three jointed articulations, which must add greatly to the efficiency of the palpi, most probably constituting them special organs of touch.

At the base of each maxilla are the mandibles. In wasps as well as bees these organs, according to several observers, supply the place of trowels, spades, pick-axes, saws, scissors, and knives, as necessity may require.

Taking into account all the varied functions 


of the apparatus known as the bee's tongue and its adjuncts, and the enormous amount of work it does for man, one is appalled at its minuteness, its complexity, and-its excellence.

The photo-micrograph from which the illustration (Fig. 22) was taken shows the object amplified to 36 diameters; the focal distance was 72 inches; the time of exposure to gas-light two minutes, and the objective used was the 2 inch.

\section{Leg of Honey Bee.}

(Apis mellifica.)

The hind legs of these indefatigable creatures are used as implements in their daily work. There is a series of modifications in the hind legs of the male, queen, and worker, so that all are different. Those of the worker are modified more highly to adapt them to their industrial occupations. This fact in Nature always arouses the keen interest of naturalists, in consequence of the difficulty that exists in connection with the creature's heredity, for 
neither of the parents is endowed with this excessive modification of the hind legs. It is admitted to be 'a very special adaptation appearing in the majority of the individuals of each generation, though nothing of the sort occurs in either parent.' *

Among the many functions of the workers' hind legs is that of acting as receptacles for carrying pollen to the nest or hive. The parts most modified are the tibia and the first joint of the tarsus or foot. In many bees other parts of the body carry pollen. Sometimes the hind legs are thick and densely covered with hairs that hold the pollen in a dry state until it is carried home.

At times the outer face of the tibia is free from hairs except at the margins, in which case pollen plates are supposed to exist. In this case the pollen is said to be mixed with nectar from the bee's mouth and rendered plastic.

The inner side of both tibia and tarsus, especially the latter, is covered with hairs; * Cambridge Natural History. 


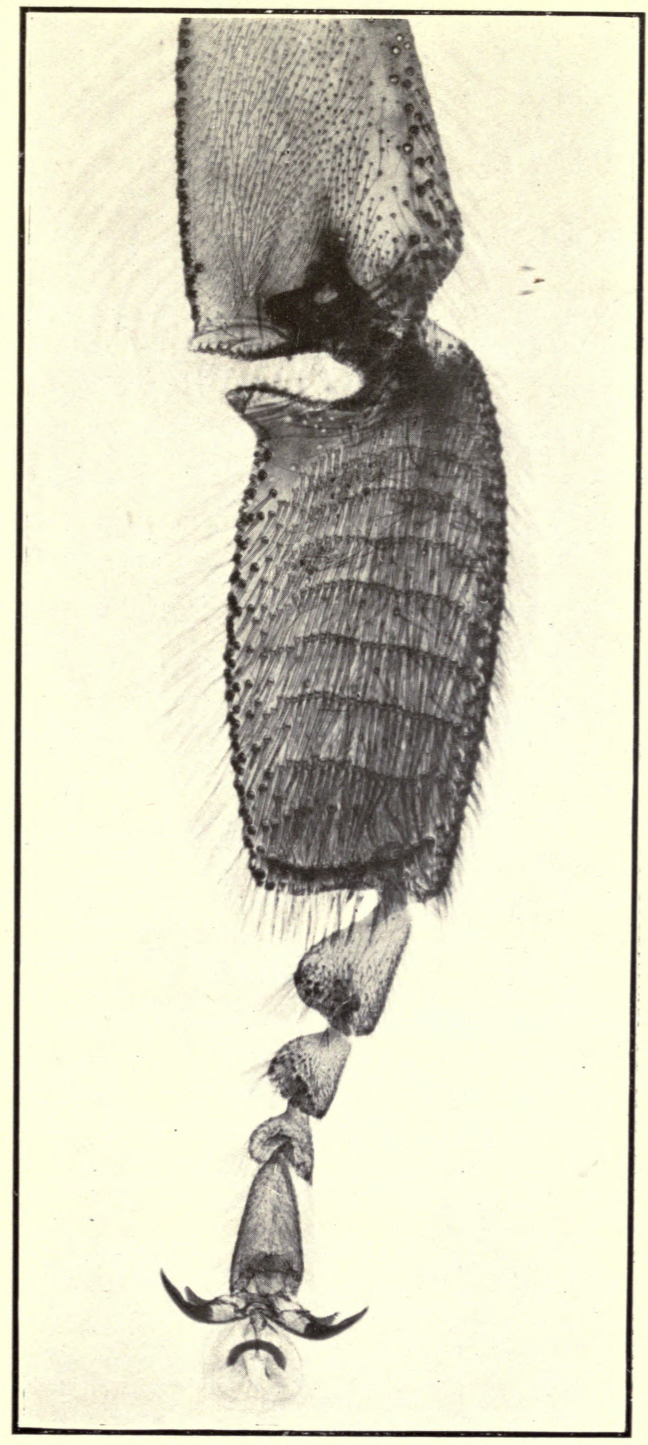

FIG. 23.

PART OF HONEY BEE'S HIND LEG.

$\times 25$.

[to face page 88. 

$=$ 


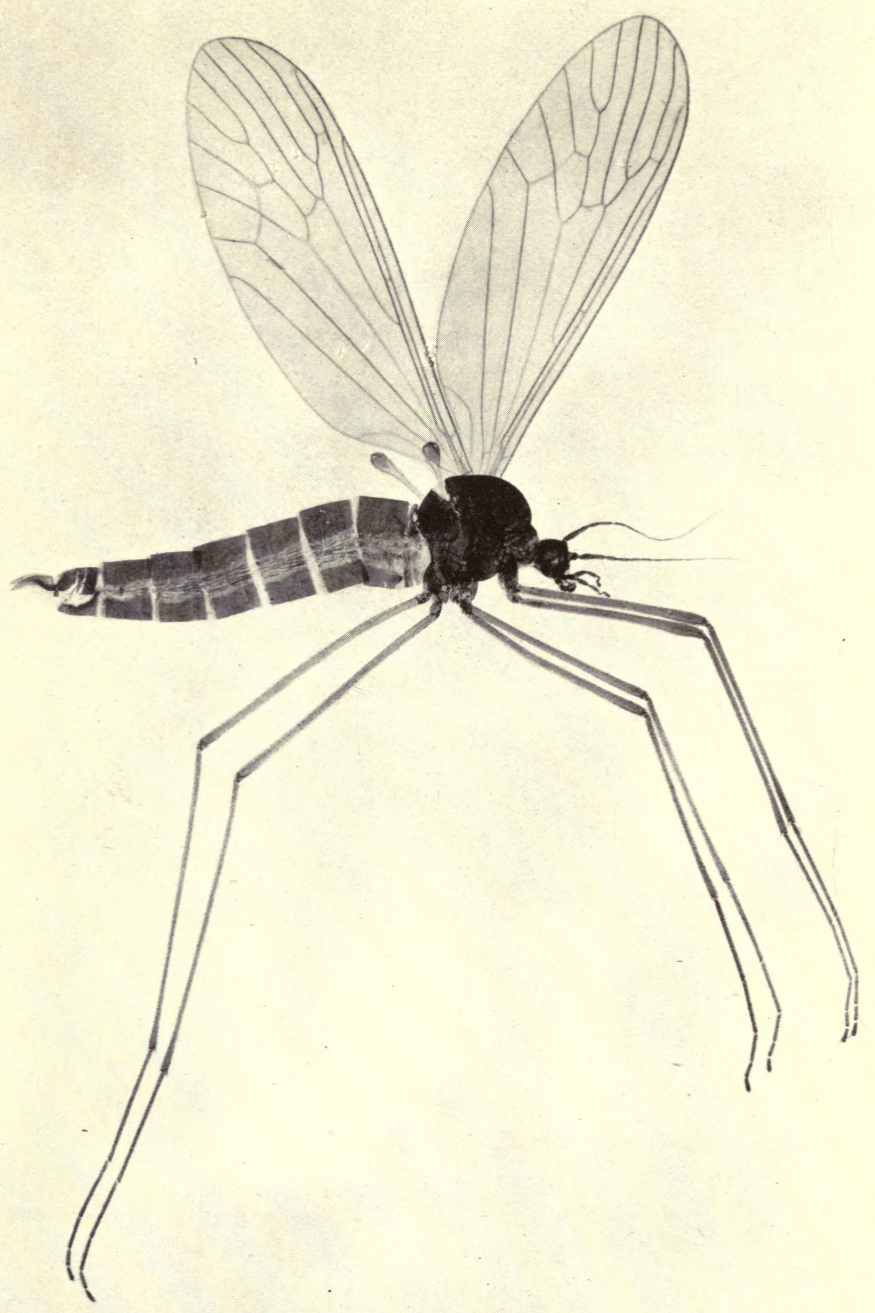

FIG. 24 .

GNAT (CULEX PIPIENS).

$\times 8$.

[to face page 89. 
those on the tarsus are arranged as in a brush, and are used for brushing the pollen from the flowers into the various receptacles on the creature's legs and body. The brush arrangement of hairs is noticeable in the illustrations.

The illustration (Fig. 23) is from a photomicrograph of 45 diameters; the focal distance was 70 inches, and the objective used was the 2 inch. 


\section{CHAPTER VII}

\section{MOSQUITO, AN INSECT NAVVY, AND}

RHYNGIA

\section{The Mosquito.}

A SCERTAINING the life-history of the A mosquito is one of the grand achievements of modern times. Several prominent medical experts have taken an enormous amount of trouble in this direction, and have even risked their lives in their desire to find some reliable means of combating or preventing malarial fever, the germs of which are carried by the mosquito.

Malaria, or ague, is a disease peculiar to man, and it is caused by an extremely minute parasite which lives in the red corpuscles of the blood. The malaria parasite is transmitted to man by the 'stab' of the mosquito.

In the main hall of the Natural History 


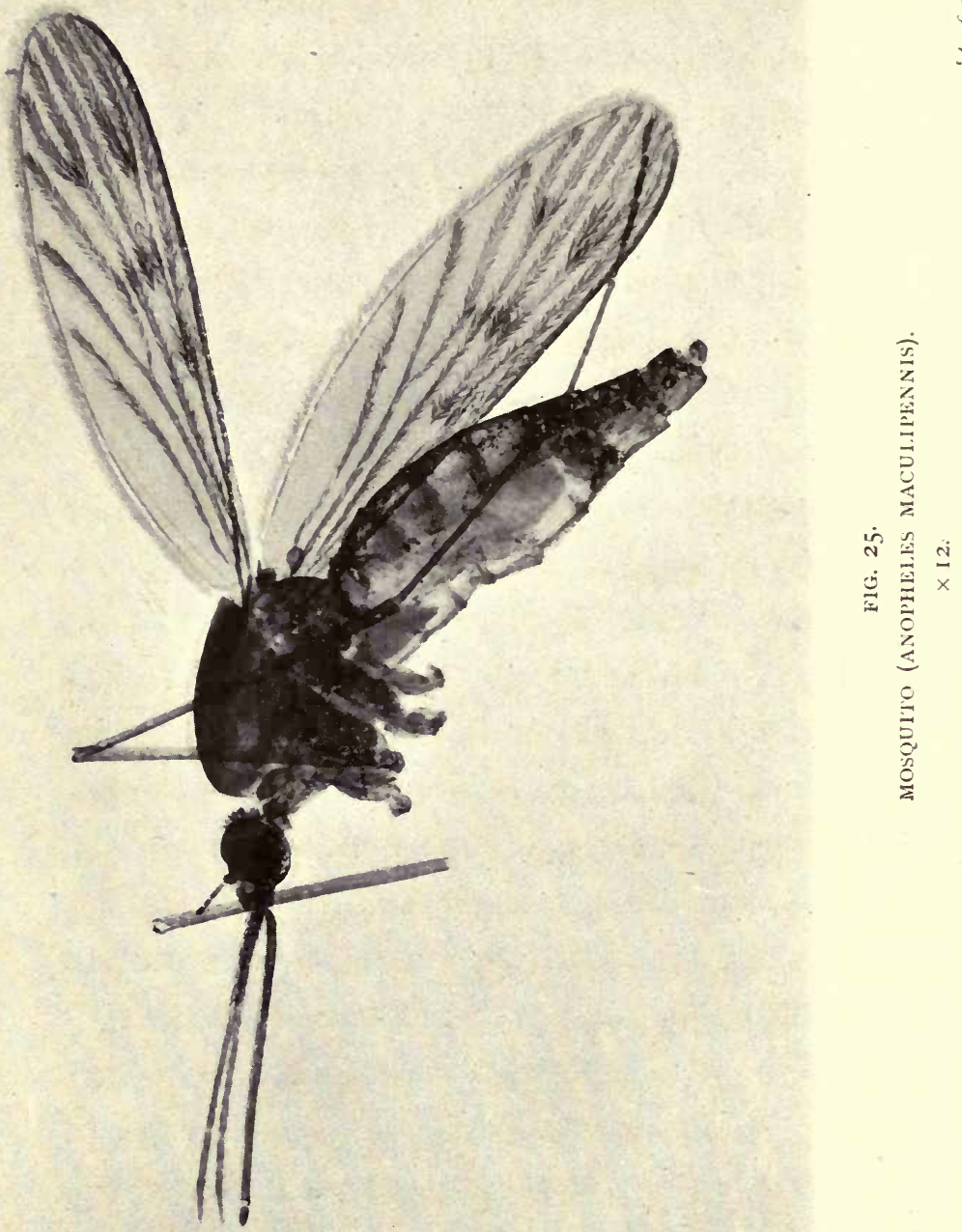


\section{MODELS OF MOSQUITOES}

Museum, Cromwell Road, are models of mosquitoes twenty-eight times as large (linear measurement) as the original insects, which are placed beside them for comparison for educational purposes.

The common mosquito (Culex pipiens) which we frequently see on our window-panes does not transmit the malaria parasite. The spotwinged mosquitoes (Anopheles maculipennis), abundant in England and nearly all parts of the world, are carriers of the malaria parasite. The parasite multiplies not only in the human blood, but in the stomach and tissues of the mosquito.

Various forms of malaria are distinguished by medical men according to the frequency of the recurrenoe of fever and other symptoms, as Tertian, Quartan, \&c. Each is due to a distinct species of parasite, though the differences are very slight.

The life-history represented by the models referred to is that of the parasite of the so-called 'pernicious' or 'æstivo-autumnal' malarial fever. The malaria parasite is an 
animal belonging to the lowest grade of Protozoa, and is allied to the Gregarines. Malaria was formerly common in England; it was then known as ague. It is now extinct in this country, but is common in Southern Europe and the Tropics, where it causes disastrous sickness and many deaths. The foregoing particulars have been obtained from the descriptive matter accompanying the models in the glass case.

In the illustration (Fig. 24) the common window-gnat (Culex pipiens) is shown. The original photo-micrograph has an amplification of 15 diameters; the focal length was 45 inches; the time of exposure was half a minute; and the objective used was the 3 inch.

In the next illustration (Fig. 25) * the dangerous mosquito (Anopheles maculipennis) is represented with its proboscis extended. The original photo-micrograph shows an amplification of 21 diameters; the focal distance was 82 inches; and the objective used was the 31 inch.

* From a micro-slide supplied by Messrs. R. \& J. Beck. 
The close arrangement of tiny hairs on different parts of the wings gives rise to the spotted appearance, and to the creature's second name, maculipennis.

\section{An Insect Nayyy. (Myrmeleon.)}

This most remarkable insect-the Ant-lion -in its larval state, is, if we are to judge by its methods of work, a navvy, and is amongst the most wonderful creatures in the insect world.

It is endowed with powers of a surprising order, and it displays an ingenuity equal to that shown by many larger animals that occupy a much higher position in the animal world.

The insect must not be judged by its appearance. This applies to creatures in a higher order of life.

Before we enter into its special claims upon our attention by enumerating any of its remarkable doings it is necessary to say something about its life-history. 
'When the larva is full grown it forms a globular cocoon by fastening together grains of sand with fine silk from a slender spinneret placed at the posterior extremity of the body. In this cocoon it changes to an imago of very elongate form, and does not emerge until its metamorphosis is quite completed, the skin of the pupa being, when the insect emerges, left behind in the cocoon. We have no Ant-lions inhabiting Great Britain, though specimens introduced do very well in confinement.'

The famous naturalist Reaumur gives us an interesting account of the creature's habits: 'The larvæ are predaceous, and secure their prey by means of pitfalls they excavate in the earth, and at the bottom of which they bury themselves, leaving only their elongated jaws projecting out of the sand at the bottom of the pit. It is a very unusual circumstance in insect life that the larva of the Ant-lion can only move backwards. In forming their pit they use their broad bodies as ploughs, and throw out the sand by placing it on their heads and then sending it to a distance by a 


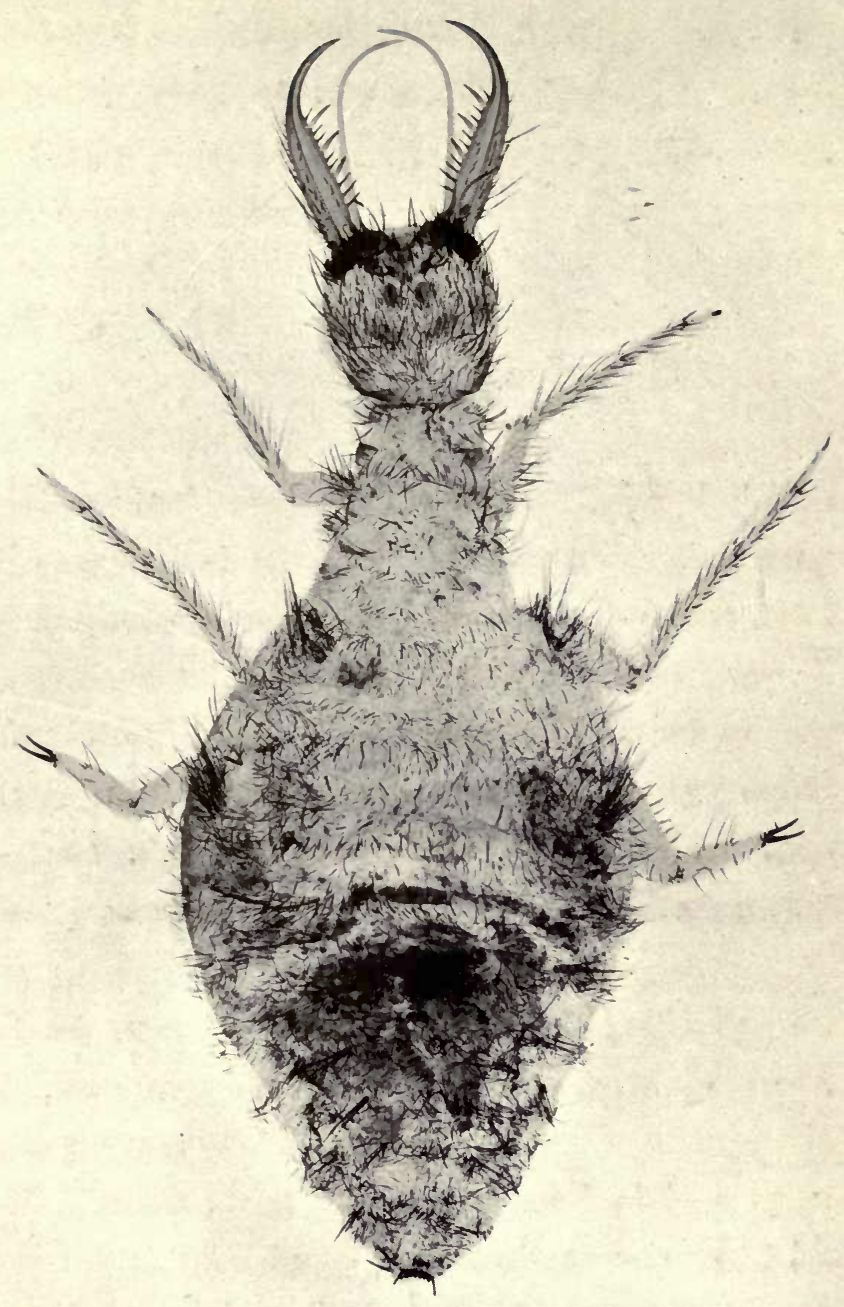

FIG. 26.

LARVA OF ANT-LION.

$\times$ I 4 . 

sudden jerk. When about to construct a trap the larva does not commence at the centre, but makes first a circular groove of the full circumference of the future pit. Burying its abdomen in the surface of the earth, the insect collects on its head, by means of the front leg, the sand from the side which is nearest to the centre, and then jerks the sand to a distance. By making a second circuit within the first one, and then another, the soil is gradually removed, and a conical pit is formed, at the bottorn of which the Ant-lion lurks, burying its body, but leaving its formidable mandibles widely extended and projecting from the sand. In this position the young Ant-lion waits patiently till some wandering insect trespasses on its domains. An ant or fly coming over the edge of the pitfall finds the sand of the sloping sides yielding beneath its body, and in its efforts to secure itself probably dislodges some more of the sand, which, descending to the bottom of the pit, brings the lurking "lion" into activity. Availing himself of his power of throwing sand 
with his head, the Ant-lion jerks some in the direction of the trespasser, and continues to do so until the victim is brought to the bottom of the pit and into the very jaws of its destroyer. The position chosen for the pitfall is in a place that will keep dry, as the larva cannot carry on its operations in damp or wet sand.'

This description of the Ant-lion's tactics is taken from The Cambridge Natural History, and fully shows the reasons for naming the creature an 'insect navvy.'

It is also remarkable that the Ant-lion has no true mouth, or orifice resembling a mouth, yet the parts which take its place are perfectly adapted for enabling it to empty its prey of its juices.

The pharynx is provided with a complete set of muscles, and, together with the buccal cavity, performs the functions of an instrument of suction.

The Ant-lion is also remarkable in that it is capable of sustaining prolonged fasts. Dufour kept specimens for six months without any 


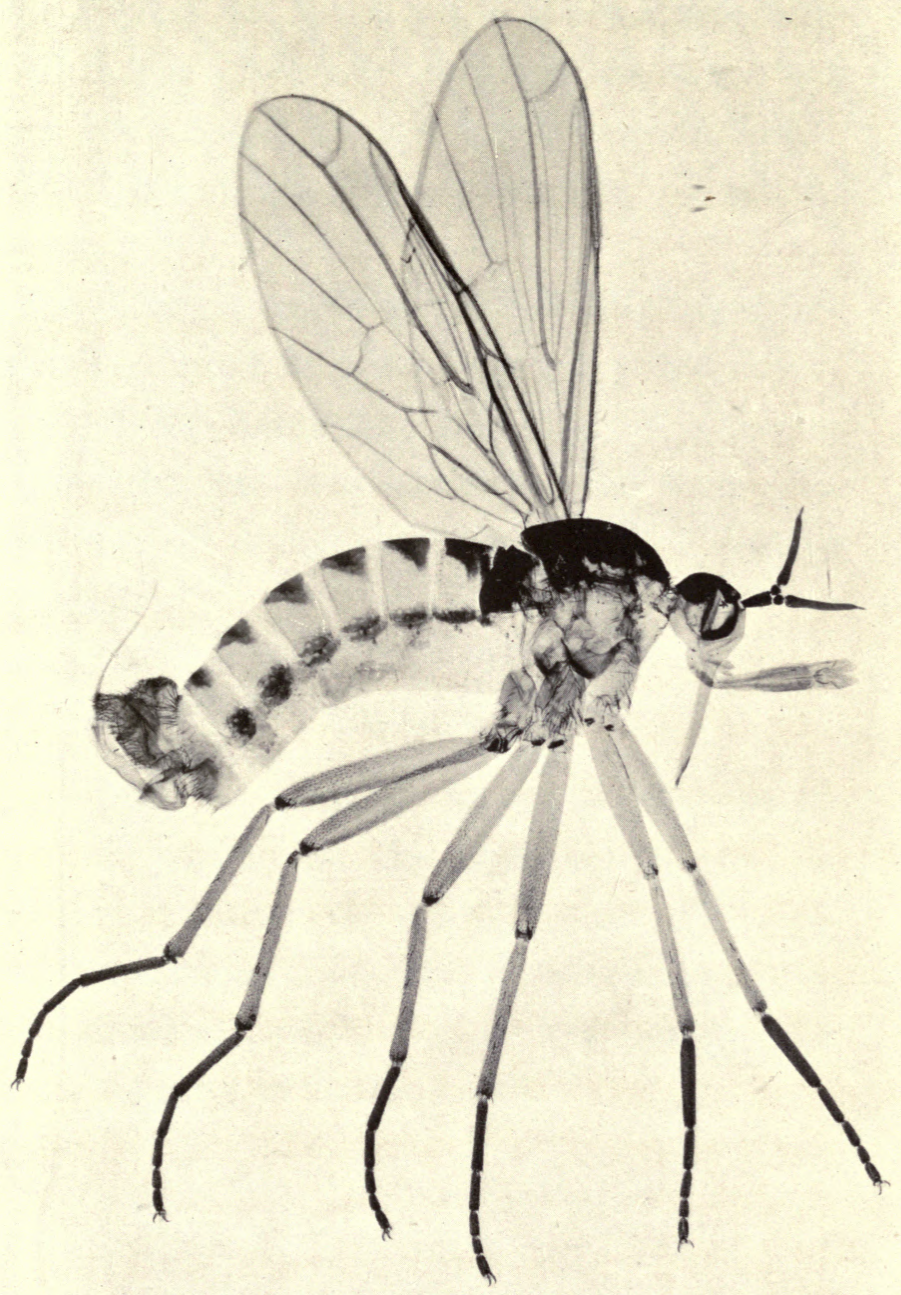

FIG. 27.

RHYNGIA.

$\times$ I8. 

food. It is to be hoped the creatures survived. The authority just quoted does not carry the account of the experiment further.

The Myrmeleon formicarius is found in Ceylon.

The illustration (Fig. 26) of this most remarkable insect is taken from a photo-micrograph of 24 diameters; the time of exposure to gas-light was two minutes; the focal distance was 48 inches, and the 2-inch objective was used.

\section{Rhyngia.}

This insect is generally known as the 'Snout Fly.' A portion of the extreme end of its proboscis is shown on the title-page (Fig. 2). The illustration (Fig. 27) is from a negative of 18 diameters, while that on the title-page is from a negative of 95 diameters. 


\section{CHAPTER VIII}

\section{HEAD OF CRANE FLY AND ANTENNA OF MELOLONTHA}

\section{Head of Crane Fly.}

(Tipula.)

П 1 it is commonly called, is a curious insect, and is known all over the world, the family being a very large one and found everywhere, irrespective of extremes of climate, altered conditions of plant-life, or any of those great changes which completely alter the character of living things in general.

Some of its representatives extend their range even to the most inclement climates, where other insects could not exist.

So far, our naturalists tell us, it is impossible to assign any reason of utility for the 



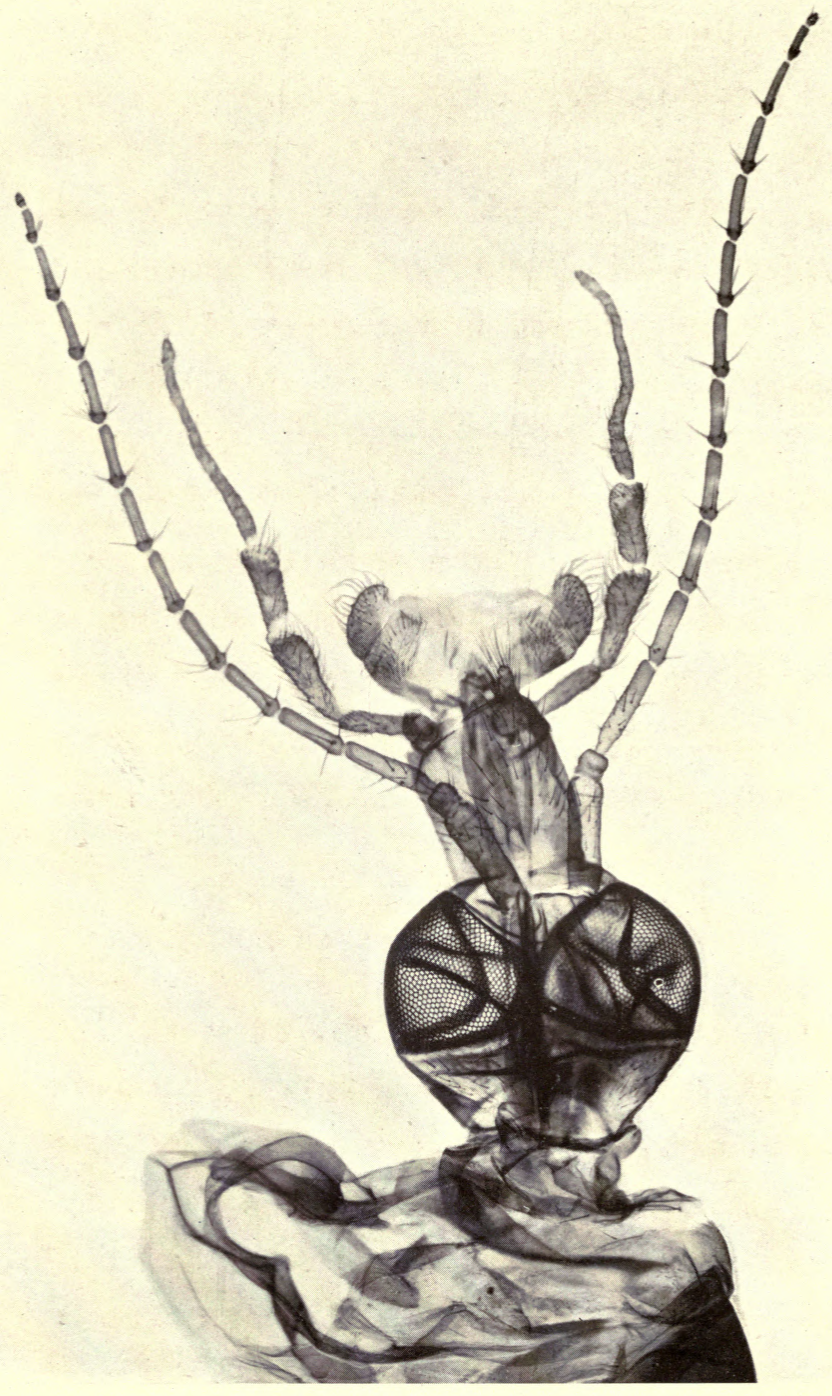

FIG. 28 .

HEAD OF CRANE FLY.

$\times$ I 5 
extreme elongation of the legs of these insects. Doubtless there is a reason, which will be discovered when we know the full particulars of its life. 'As every one knows, the legs break off with great ease, and the insect appears to get on very well without them. It is frequently the case that they are much longer in the males than in the females. Other parts of the body exhibit a peculiar elongation; in some forms of the male the front of the head is prolonged into a rostrum. The larvæ exhibit a great variety of form, some being terrestrial, others aquatic; but the terrestrial ones seem all to delight in damp situations, such as shaded turf or rotten tree-stems. There are more than a thousand species of these flies known and many genera.'

In the illustration (Fig. 28) the eyes of the insect attract special attention and the highest admiration from every one who studies them. They are faceted, and are of wonderful complexity and delicacy.

They are totally different in structure and very distinct in function from the eyes of the 


\section{THE CRANE FLY}

vertebrate animal, and are seated on very large special lobes of the brain. These lobes, indeed, are so large and so complex in structure that the insects may be described as possessing special ocular brains brought into relation with the lights, shades, and movements of the external world by a remarkably complex optical apparatus.

The illustration is taken from a photo-micrograph representing a portion of the insect as if amplified to 35 diameters. It is the result of one minute's exposure to gas-light. The focal distance was 70 inches, and the objective used was the 2-inch.

\section{Antenna of Melolontha.}

This object, one of the antennæ of the cockchafer, is well adapted for photographic purposes, and can even be sketched in outline with great ease by using the camera lucida.

Throughout the whole surface of this compound appendage an enormous number of small circular cavities is observable. If 



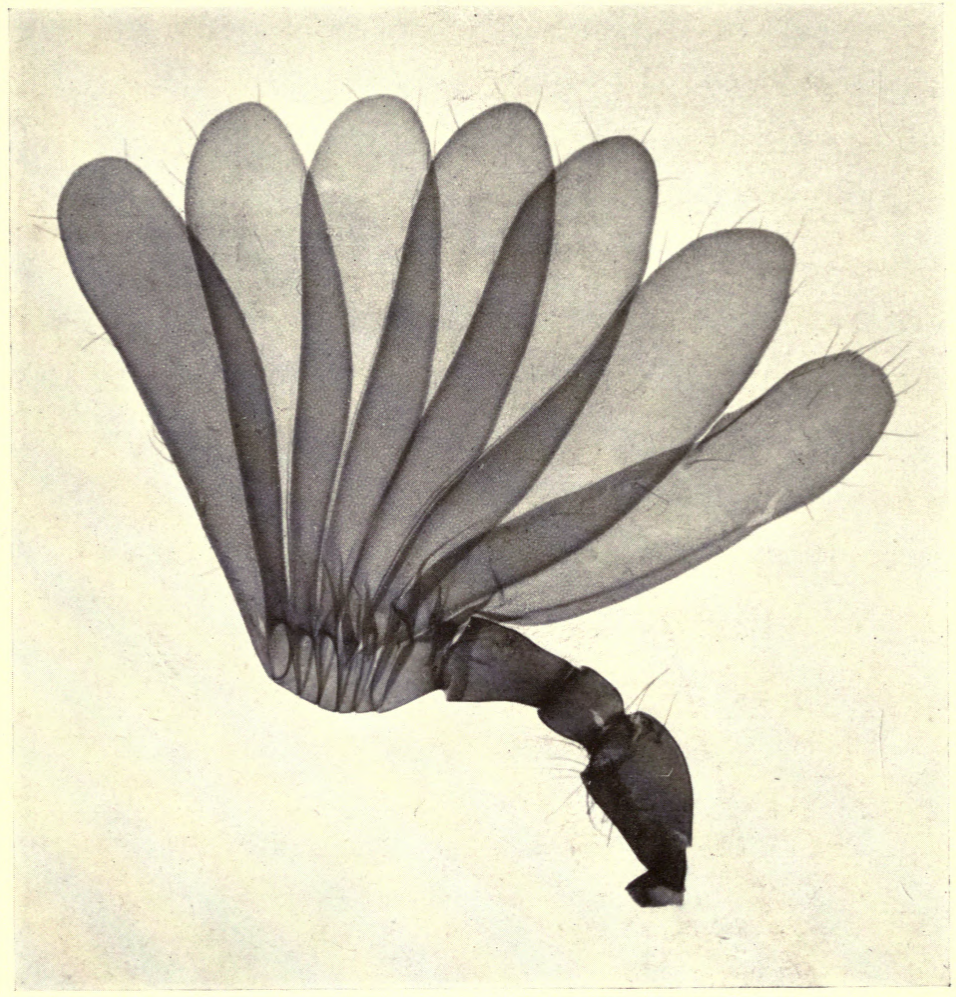

FIG. 29.

ANTENNA OF COCKCHAFER (MELOLONTHA).

$\times$ I 5 .

[to face page ror. 
modern observations be correct, these tiny cavities have an important duty to perform, and a great gain has been made with regard to our knowledge of this creature.

Dr. Hicks, in his work On a New Structure in the Antennce of Insects, seems to show conclusively that the sense of hearing is inseparably connected with these innumerable concavities spread over the divisions or appendages that make up an antenna.

Burmeister suggests that a soft articulating membrane at the base of each antenna, which can be rendered tense or otherwise by the movements of the antenna, represents the drum of the ear; also that it is so placed as to receive impressions of sound vibrations.

That the insects possess the sense of hearing need not be doubted.

The wonderful antennæ of the melolontha doubtless have special duties to perform as well as to act as receivers of sound waves. They are organs of touch; this sense is bestowed upon all insects, and to judge from the perfection of the structures which some 
insects build, and the mathematical accuracy of their work, their sense of touch must be extremely delicate. This sense is generally believed to be specially localised in the antennæ.

The varied movements of the lamellæ of the antennæ of the cockchafer may be realised by the opening and folding over of the several divisions of a carved ivory fan.

The original photograph of this antenna (Fig. 29) shows an amplification of 36 diameters. The time of exposure was 4 minutes to gas-light; the focal distance from plate object was 72 inches. A 2-inch objective was used. 



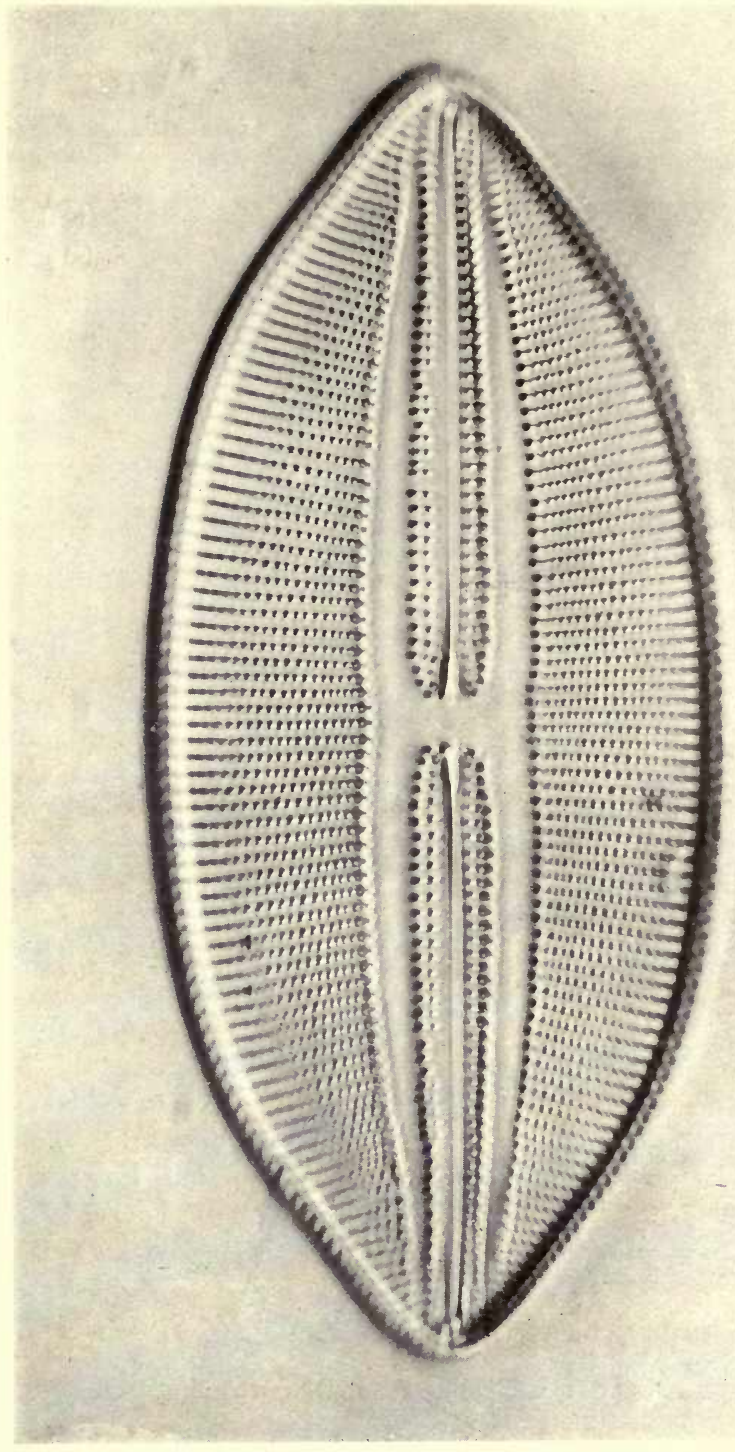

FIG. 30 .

DIATOM, NAVICULA LYRA.

$\times 900$ 


\section{CHAPTER IX}

\section{DIATOMS}

D

IATOMS constitute a group of microscopic plants found all over the world in most waters-fresh, brackish, or salt. They are yellowish-brown in colour, and consist of a single cell, free or adhering in chains or planes. A coat of silica invests the plant. This coat is composed of two valves, generally alike, joined together by connecting girdles. It is the opinion of some authorities that the flinty structures are skeletons arranged in symmetrical halves and joined at their margins by an intermediate rim or hoop. The valves are of various forms, and their surfaces exhibit delicate markings. Many of these united valves or skeletons are not 
unlike pill-boxes, each with a lid, bottom, and rim. Some are oblong, others sigmoid, elliptical, triangular, \&c.

Diatoms were formerly placed in the animal kingdom, chiefly because they are able to move. A more exact study of their structure and mode of nutrition shows that they must be classed with the lower Algæ.

Diatoms increase in number by successive division into two, in such a manner that succeeding generations are diminished in size. This diminution is owing to the fact that the wall of the older portion overlaps that of the younger, and the diminution therefore corresponds in extent with the thickness of the wall. This process goes on through a series of generations, the minimum size being about half the maximum. When the minimum is reached, the wall is cast off, the contents become rounded in form and increase in size, and a new individual of the maximum size is produced. The late Professor W. Smith estimates that no less than a thousand million individuals may be produced 
by division from a single plant in one month !

Vast numbers of these organisms are peculiar to the open sea, and they possess a sufficient degree of buoyancy to enable them to live and to move amongst its waters without the aid of any supporting body whatever. Their buoyancy and power of movement are entirely independent of the ordinary to-andfro motile power shared by them, in a greater or less degree, with all the other free forms of Diatomaceæ.

It is impossible to conceive the extraordinary abundance of diatoms throughout the world. According to Ehrenberg, they have exercised an important influence in blocking up harbours and diminishing the depths of channels. A mud deposit, consisting, chiefly, of their siliceous valves, no less than 400 miles long by 120 miles broad, was found at a depth of between 200 and 400 feet on the flanks of Victoria Land in $70^{\circ}$ south latitude.

Deposits of diatoms are found in tertiary 
and post-tertiary strata. The Bergmehl of Norway is composed of fresh-water species. Small deposits have been found underlying beds of peat in Great Britain and Ireland. A bed 25 feet in thickness, composed entirely of marine species, and extending over a large area, occurs at Richmond, in Virginia. Similar beds exist in other countries.

No mind, however mathematical, can have any conception of the numerical strength of these lowly yet magnificent organisms. For example, in the Botanical Department of the Natural History Museum, Cromwell Road, a glass case contains a block not more than two cubic feet in measurement. It contains not fewer than 12 billion $(12,000,000,000,000)$ individual plants! This block representing so much life could be carried under the arm with ease. Figures must fail to help us when trying to form an idea of the life represented in the deposit in the Antarctic Ocean, 48,000 miles in area, or in the fossil deposit of Virginia.

With regard to this almost cubical block, 


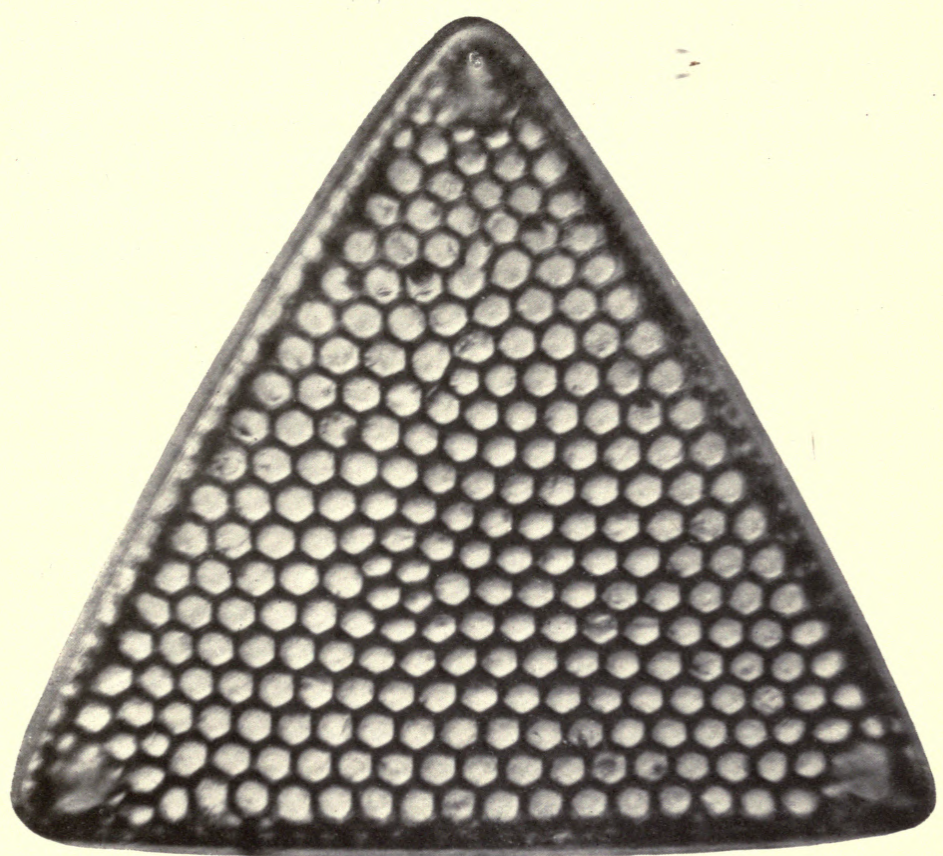

FIG. $3 \mathrm{I}$.

DIATOM, TRICERATIUM FAVUS.

$\times 600$.

see page r 10.

[to face page 106. 

the contents of the cells and the whole tissue of the plants have gone except the siliceous coats. The mass is from a fresh-water lake in Australia. Year after year the diatoms in myriads lived for a short time in the water; when dead, the organic portions decayed, and the remaining imperishable siliceous coats fell to the bottom of the lake, and in time formed the pure deposit of which this is a fragment.

'As regards the longevity of diatoms,' says the Rev. F. Wolle (Diatomacea of North America), 'it may be said that dried specimens cannot be revived, but they have been known to survive nearly a quarter of a century in their natural element, even though kept for long periods in the dark, and at times frozen in solid ice. Their siliceous covering is almost indestructible, resisting the strongest acids and passing unscathed through very high degrees of heat.'

Specimens for mounting can readily be collected in a wide-mouth bottle, with some fine muslin to act as a net. When the 
diatoms are attached to the stems of other plants under water, it is best to remove the stem with its specimens. Very frequently, however, they are only entangled in the meshes of confervæ, and can be obtained by the usual ring net employed by microscopists. The surface mud of ponds generally contains large supplies of beautiful representatives of this remarkable family. To separate them from the sand, \&c., the contents of the bottles should be placed in distilled water and allowed to remain for a time, when the sand, being the heavier, will collect at the bottom, and the diatoms may be skimmed off.

A few words more as to the markings which the surfaces of the diatoms exhibit. Some of them are arranged in lines, parallel or radiating, or assume the outline of the individual specimen. Some markings appear as dots, others as if crossing each other. Many naturalists believe that the markings are depressions, but as different effects may be obtained by different methods of illumina- 


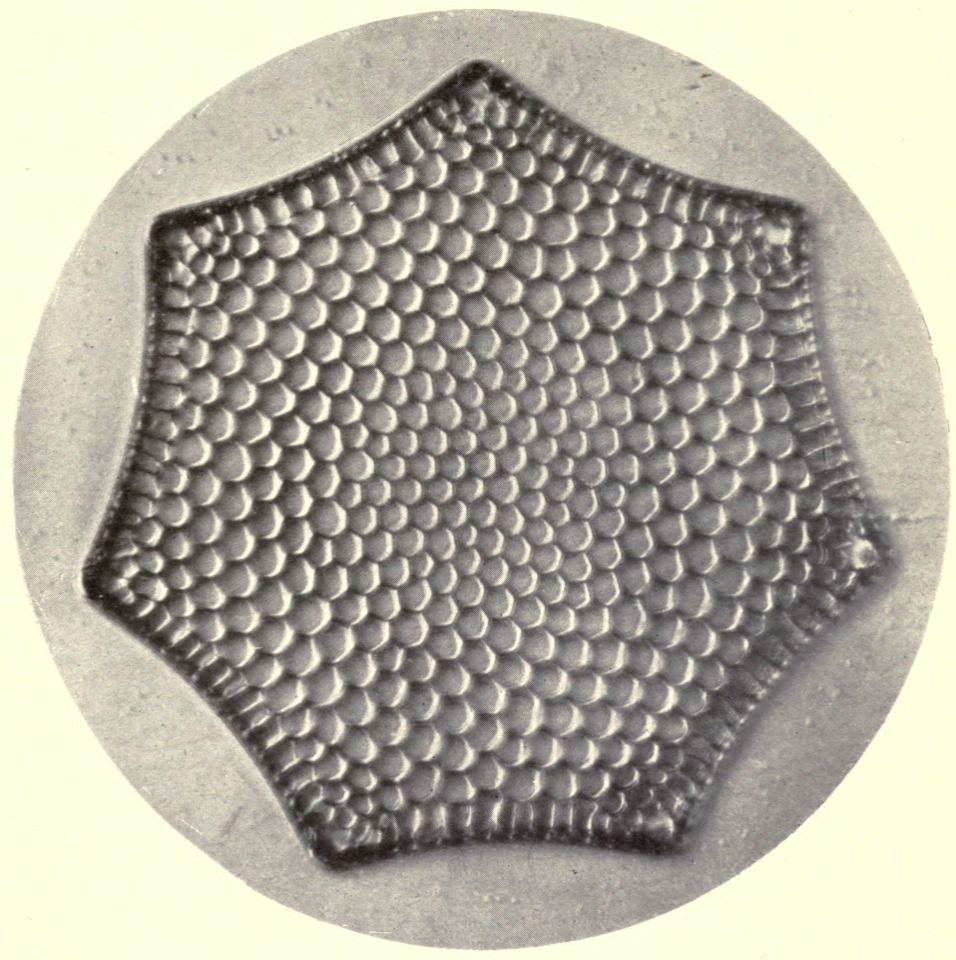

FIG. 32 .

DiATOM, TRICERATIUM FAVUS, VAR. SEPTANGULATUM. $\times 280$. 

tion, the question of hemispherical elevations or cup-like sculpturings is by no means settled. It remains, however, that these tiny objects, although so very small that many of them are on the borders of our vision, or even below unassisted sight, are decorated with thousands of lines and markings in fixed, definite, symmetrical order, each kind of diatom having its own special markings characteristic of its group. Very high powers of the microscope reveal not only surface or primary patterns, but also secondary or even tertiary markings. Mr. E. M. Nelson, who is deservedly looked upon as a recognised authority on the study of these wonderful products of Nature, admits that even with the highest microscopical powers he is not able to exhaust or reach the limits of design in a diatom! Complex designs involving the symmetrical arrangement of many thousands of lines and dots on a speck of flint that is too small to be seen without a microscope! The seven artificially-constructed wonders of the world, whatever they may be, are not to 
be compared with these marvels of regularity and exquisite beauty.

To illustrate this chapter there are six pictures. The first is taken from a photomicrograph of 1,500 diameters. The diatom is Actinocyclus ralfsii (Fig. 6). Under the microscope this object gives a display of colour very much resembling the action of a diffraction grating.

The second is a magnificent diatom (Fig. 5). In the original photo-micrograph it shows an amplification of 2,500 diameters! It was found in clay in Hungary.

The third is Navicula lyra (Fig. 30). The illustration is from an amplification of 1,500 diameters; the exposure was 60 minutes; the focal length 40 inches; an eye-piece of 7 diameters; and the $\frac{1}{6}$ th objective were used.

Next comes the 'sun shield,' Heliopelta metii (Fig. 3). The illustration is from a photo-micrograph taken under a magnification of 580 diameters. No collection of diatoms can be representative without this specimen. 


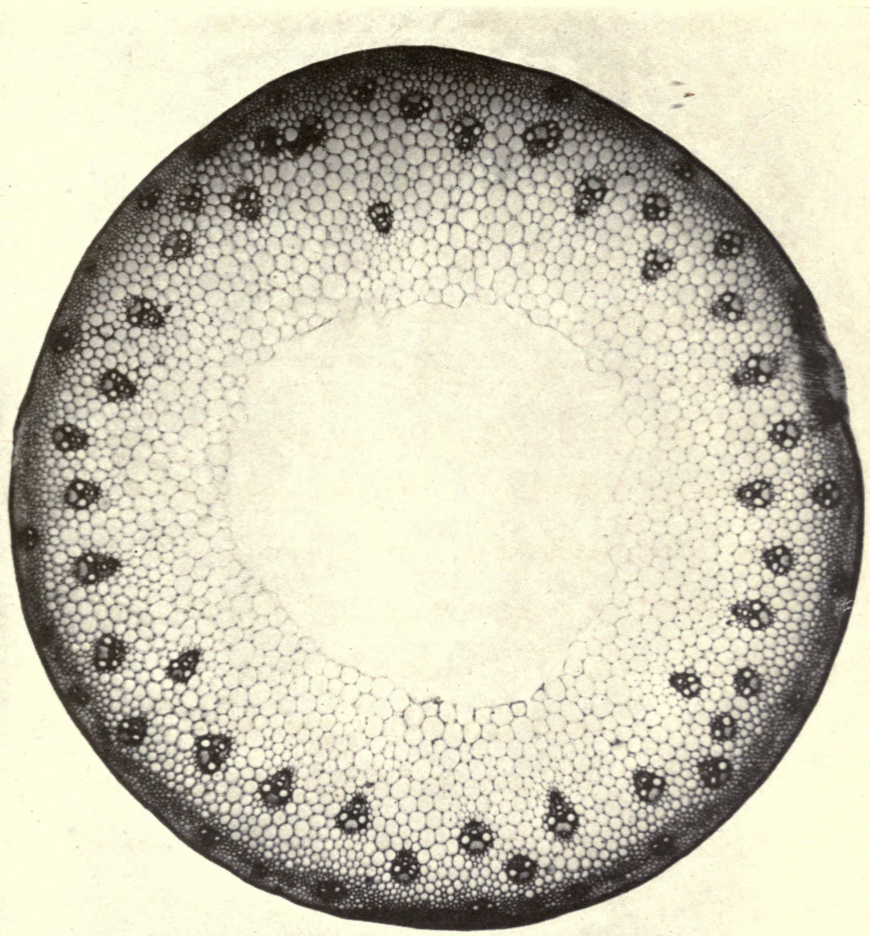

FIG. 33 .

SECTION OF WHEAT-STEM.

$\times \mathrm{I} 5$.

[to face page iro. 

Triceratium favus (Fig. 31) follows, and is from an amplification of 1,375 diameters.

The next illustration (Fig. 32) is that of Triceratium favus, var. Septangulatum, and is from an amplification of 640 diameters.

The last illustration (Fig. 4) of the diatom series is from a photo-micrograph of 1,750 diameters. Only a small portion of this diatom is seen. It is that of Coscinodiscus bi-angulatus.

That there are thousands of markings on the surface of any one of these diatoms is evident. If we try to realise this fact-and that several diatoms are so small that we can barely see them, while many are completely below the powers of the strongest eyes-we shall have something that will test our thinking-powers, and that may induce us to take a deeper interest in Nature-study. 


\section{CHAPTER X}

\section{SECTIONS OF WHEAT STEMS, AND DODDER ON CLOVER}

\section{Section of Wheat Stem.}

ПНЕ illustrations reveal a marvellous 1 arrangement of cells in simple sections of an ordinary plant. The perfect order and the way in which they are all disposed in so limited a space as the thickness of a stem of wheat is most surprising. There are few, if any, of our grasses which have a more remarkable history than that of the common wheat, Triticum vulgare. For this, and for other apparent reasons, information about this plant should be well studied by everybody. The plant is, of course, known to every one; but few are aware that it is derived from a wild 



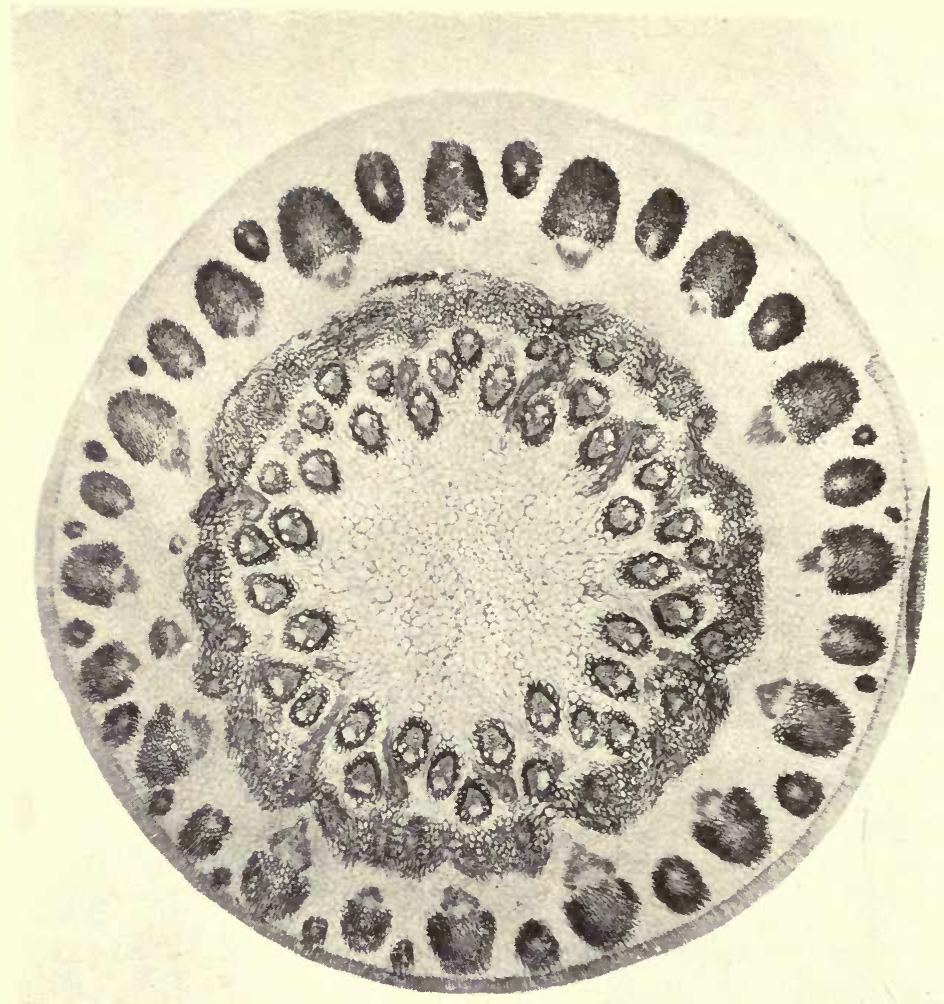

FIG. 34 .

SECTION OF WHEAT-STEM THROUGH THE NODE.

$\times 15$

[to face page $\times 13$. 
grass of Southern Europe and Western Asia. That a wild and apparently useless grass, very dissimilar from wheat, should by careful cultivation become so changed as to afford a useful and nutritious grain for the food of many nations in countries widely separated, is a proof of the advantages of civilisation, whatever may be advanced against it. But this is not all. Its adaptability to circumstances renders it capable of easily affording a large series of varieties. No plant is so easily adapted to the variations of climate, soil, and management as is wheat. It has a wider geographical range than most plants. Rice, maize, and wheat may be said to support the greatest number of the human race.

The eminent botanists, M. Fabre in France, and T. Moore, of The Treasury of Botany fame, have taken the wild grass Fgilops and placed it under modern methods of cultivation. In the course of a few years, they had the gratification of seeing good ears of wheat gradually emerging, as it were, from the formerly wild grass. Many of the plants rose 
to 2 feet in height with spikes and flowers containing as many as twelve spikelets.

The genuineness of the connection between the grass Fgilops and our wheat is established by the fact that the bruised foliage of the wild grass and the cultivated wheat both emit the same odour; still further, both are subject to the attacks of the same species of parasites (blights).

Wheat and other cerealia contain in their herbage, and especially in their seeds, nutritious principles which entitle them to take first rank amongst the plants useful to man, and of the greatest importance from an economic point of view.

Besides starch, sugar, and mucilage, they yield sulphoazotised matters such as fibrin, casein, albumen-elements essential to the formation of flesh in animals; especially do they yield phosphate of lime, the basis of their bony framework.

A very curious experiment can be performed with a growing stem of wheat. There are to be noticed, at considerable distances apart, certain knot-like swellings-nodes-sharply 
marked off from the thin cylindrical parts and usually coloured differently. One of these knots with a portion of the stem above and below, comprises a ' haulm.'

'If a haulm be bent sharply above the soil, while growing, so that the whole of its upper part comes to lie horizontally, it will be noticed after from two to four days that a knee-like curvature has been formed at its node, in consequence of which the apical portion of the haulm again erects itself vertically; as a rule two or three nodes take part in this change, the nodes being about the knee-like formations. The result is known as geotropic curvature. The curvature of the node is due to the fact that its under side, when placed in the unwonted horizontal position, becomes considerably elongated as a result of vigorous growth, while the upper side grows feebly or not at all, or even often becomes considerably shortened.

'If a scarlet runner growing erect in a vessel be inverted and left upside-down for some hours, it will, even in that short time, show geotropic curvature of the mobile organs.' (Sachs.) 
The illustration (Fig. 33) is taken from a photo-micrograph of 36 diameters. It was done on a process plate owing to the section being exceptionally weak. The time of exposure was 3 minutes; the focal distance was 36 inches, and the objective used was the 1-inch.

It will be observed that this portion of the stem is a hollow cylinder. The fact is that the original central cellular tissue was torn up and destroyed in the process of growth. Surrounding the central hollow is the cellular tissue, while the dark patches are fibro-vascular bundles. The outer dark margin consists of closely-packed epidermal cells.

In the next illustration (Fig. 34) we have a section through one of the nodes. The epidermal cells constitute, as in the previous instance, the thin outer limits of the stem. The wide band inside these limits is the sheath, or base of the leaf, containing fibro-vascular bundles in the midst of cellular tissue.

Further in we have the stem within the leaf, also with fibro-vascular bundles. The central 
cellular tissue is here intact, being young. This illustration is also taken from a photomicrograph of 36 diameters; the focal distance was 36 inches; and a 1-inch objective was used.

\section{Dodder on Clozer.}

The dodder is not only devoid of roots and leaves in the strict sense, but is destitute of green colouring matter, the substance which helps to elaborate the food of plants, and occurs so abundantly in clover, from which dodder draws its nutriment. It does not possess any of the small mouths or organs of transpiration possessed by ordinary plants.

It is also remarkable in another respect. It is generally agreed that dodders produce an acrid and purgative juice, detrimental to flocks and herds. The question naturally arises, Where do they obtain these injurious principles ? It is certainly singular that a parasitic plant should be capable of elaborating acrid juices from the sweet non-acrid sap of its host. 
A plant exhibiting so many exceptions to the laws which govern ordinary plant-life must of necessity possess some points of interest in its structure and habits. Omitting minute details, dodders are plants with yellowish or reddish, leafless, threadlike stems, the leaves being represented by a few small transparent scales. The small bell-shaped flowers are packed closely together in clusters. The threadlike stems are furnished with numerous very small suckers with which the parasite attaches itself to its host.

It is extremely common to find seeds of dodder amongst impure clover seeds imported from the Continent. It is not always easy to sift dodder from the clover. Clover seeds send their roots deep into the earth, while the dodder seeds are sending their threads into the air in search of a host on which to live parasitically. Ultimately they succeed in reaching the young clover seedlings. When the dodder twines round a seedling clover the rapidly-growing clover carries the dodder away from the ground. As 


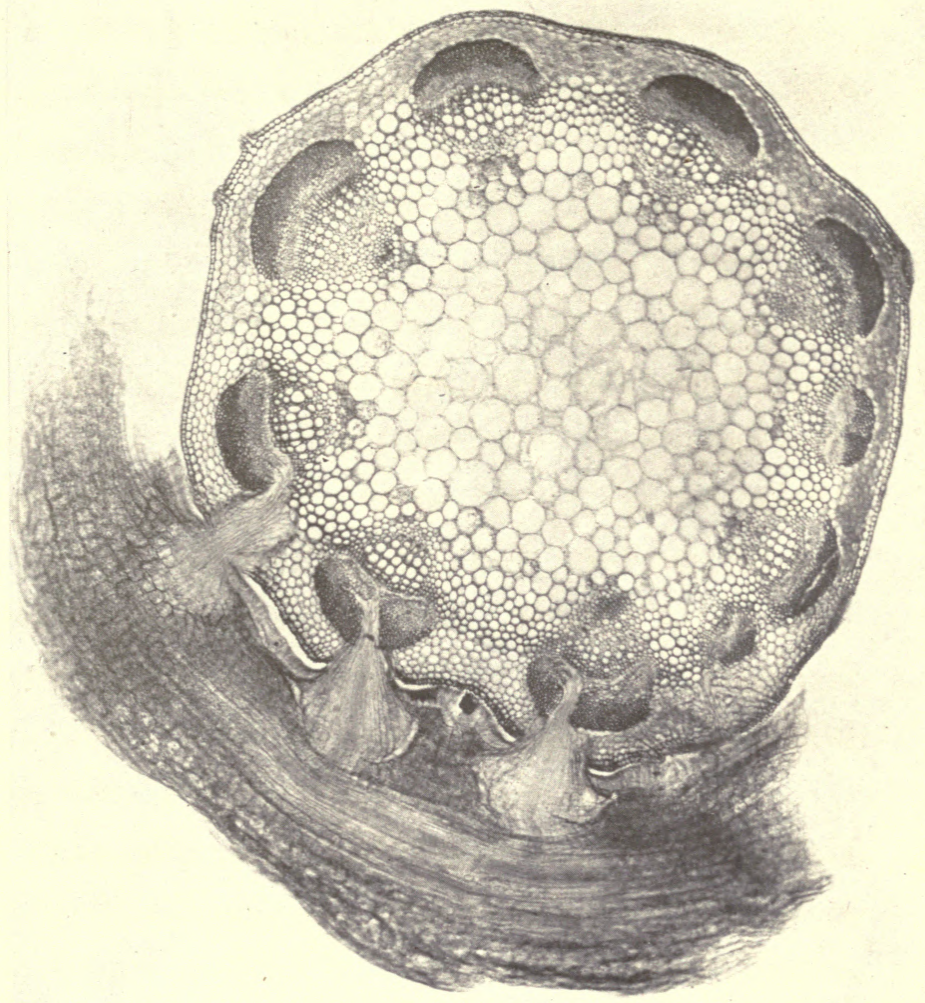

FIG. 35 .

DODDER ON CLOVER.

$\times 36$.

To face fage 113 . 

the clover grows the dodder grows with it, and the parasite is lifted higher from the ground. As the spring and summer advance, the dodder flowers profusely, and as the clover plants grow in size and come in contact with each other, the dodder spreads from one host to another. The dodder, in growing, branches and re-branches repeatedly, and throws out long arms, so that during a single summer one or two infested clover plants will help to spread the dodder over a large area. The parasite cannot live on the remains of the plants it has destroyed, so, in the process of growth, it leaves the central clover plant for other plants at the circumference of a dead circle of clover, which may be many feet, or even yards, in diameter.

The suckers, already mentioned as being useful to the dodder in enabling it to attach itself to the clover, are pushed into the fine longitudinal furrows (which are always present on clover stems) until they reach the internal cellular structure of the clover. Each sucker being provided with a woody skeleton, it acts 
like a small thorn, and is thus enabled to pierce the clover stem. The parasitic life of the clover dodder commences with the insertion of the first sucker into the host plant. When the pith is reached by the suckers pushing themselves in between the cells of the stem of the host, the cellular tissue of the dodder comes into close contact with the living cells of the clover, with the result that the vital juices elaborated by the clover pass through the cell walls of the clover into the cells of the dodder; thus the sap of the clover feeds the parasite by transfusion.

The dodder grows with such extraordinary rapidity when it has once fixed on clover, and it produces so many branches and branchlets, with such a vast number of suckers, that the growth of the parasite usually far exceeds that of the host. The consequence is the dodder completely drains out the elaborated juices of the clover, and kills it by exhaustion. The destruction of the clover is also hastened by the great weight of the accumulated masses of entangled dodder. Every 
patch of dodder should be carefully raked together and burnt, and by this process and careful sifting its appearance in the fields can generally be prevented.

In the illustration (Fig. 35) part of the enclosing stem of the dodder is seen with three of its suckers inserted in the almost circular section of the clover stem. In the original photograph an amplitude of 80 diameters is shown; the focal distance was 40 inches; the exposure to gas was 5 minutes, and the half-inch objective was used. The section of the clover stem displays a beautiful arrangement of cells.

Looking again at the section, the outer margin of the portion of dodder shown consists of cellular tissue; next to that is the woody cylinder. The three suckers of the dodder are distinctly seen inserted in the clover. With regard to the clover part of the section, we see inside the margin about ten fibro-vascular bundles; all the remaining cells towards and at the centre are loose cellular tissue. 
All the foregoing details descriptive of the dodder I have taken from $\mathrm{Mr}$. Worthington G. Smith's excellent work on Diseases of Field and Garden Crops. 



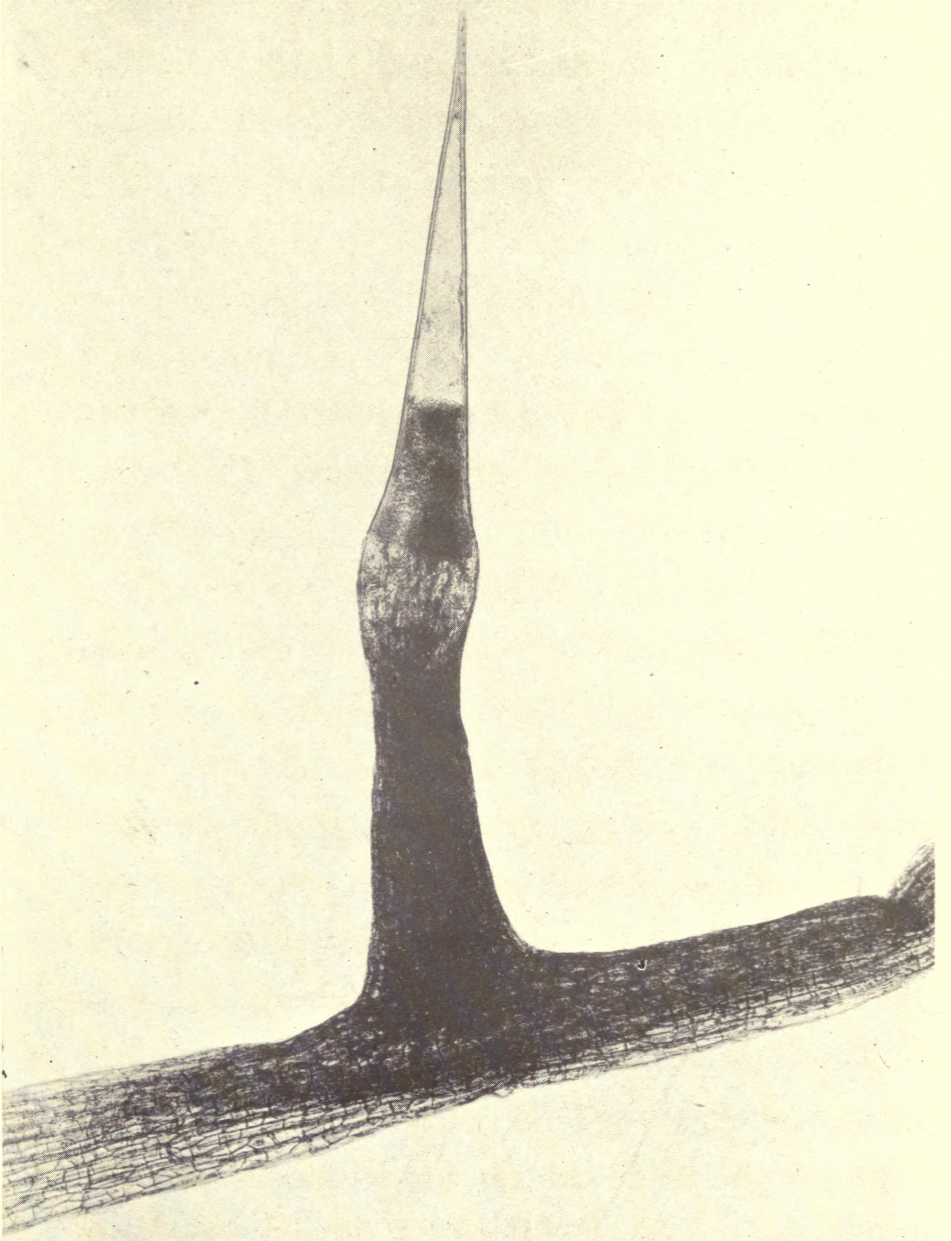

FIG. 36 .

STING OF NETTLE.

$\times 55$

[to face page 123. 


\section{CHAPTER XI}

STING OF NETTLE, ARISTOLOCHIA GIGAS, AND CALAMUS ROTANG

\section{Sting of Nettle.}

THE sting of a nettle is shown in the original photograph amplified to 100 diameters. In reality the sting is a plant hair which is tubular, unicellular, sharply conical, and terminating at the top in a small $\mathrm{knob}$, which in this instance has been broken off. At the base the sting, or hair, broadens out, is bulb-like, and fits into a cup which is developed from the tissues of the leaf. The bulb contains the acrid fluid which causes so much pain, and frequently raises blisters on the hand that touches it. As the hand is rubbed against the nettle the knob is broken 
off the sting, and immediately a free passage is made for the irritant fluid to pass into the wound. If the sting be broken off below the point, as is the case when it is grasped firmly, the poison is poured on the skin instead of underneath it, and is not felt.

In this country we are more fortunate as regards the nettles than our friends in Australia. In New South Wales some nettles, notably the Urtica gigas, are formidable trees in more senses than one, and they frequently form a great impediment to the traveller. They vary in size from 20 feet to 120 feet in height. Their leaves attain a breadth of 15 inches. The poisonous fluid secreted from the foliage is excessively virulent, especially in the younger leaves. It produces intense pain, and often leads to dangerous results.

There is, however, another side to the lifehistory of the nettle. In all countries in which the nettle thrives it is a most useful plant, whatever the species may be. The stinging-nettle of our hedges and roadsidesUrtica dioica - is cooked and eaten as a vege- 
table. The Belgians and Germans use it for this purpose more than we do. In this form it is looked upon as a blood purifier.

Sir Walter Scott mentions the fact that the nettle was cultivated in Scotland as a potherb.

The young tops of nettles, when dried, form a good food for cattle. The fresh tops are enjoyed by pigs, and when chopped up they make an excellent food for fowls and young turkeys. Both the dried leaves and the seeds are given to fowls in winter-time to make them lay eggs. In Holland and other countries, horse-dealers mix seeds of nettles with oats or other food to give the animals a sleek coat. Many of the nettle tribe have medicinal properties-astringent, aperient, diuretic, \&c. The excellent fibres they produce are used for making hemp, ropes, cordage, fishing-lines, cloth, and even lace. Specimens of lace from nettle fibre made by peasant women in Ireland may be seen in the chief museum in Kew Gardens.

Looking fairly at the shortcomings and the 
virtues of the nettle family, we are bound to conclude that the latter outweigh the former, and that nettles are most useful plants, even if troublesome when touched incautiously. There are one or two facts about the nettle which we must not omit to notice. The ease with which the sting penetrates the human skin is accounted for by the fact that its walls are composed of flint, as may be easily proved by heating it red-hot on a plate of mica. If the sting be carefully removed from the growing plant, the streaming of the protoplasm can be distinctly seen. The cuticle shows oblique striation, which ascends in the same direction in all stings.

As already stated, the illustration (Fig. 36) is from a photo-micrograph, showing the sting as if enlarged to 100 diameters; the focal distance was 45 inches, and a half-inch objective was used.

\section{Aristolochia gigas.}

A section of this remarkable plant is shown in the illustration. Its peculiarity is at once 
noticeable in the arrangement of its vascular bundles in the shape of separable wedges, and in the absence of concentric rings or zones. The wood of this plant differs in appearance from that of exogenous trees or shrubs, as it consists of radiating plates of wood surrounding a pith and encircled by bark.

The section shows at the centre the pith containing cells, and around this a belt of isolated vascular bundles in which the wood is the darker portion, pierced with holes, which latter are sections of vessels.

The plants of this genus are for the most part shrubs, generally climbing round the branches of trees. They abound in tropical South America.

The flowers of some of the kinds are remarkable for the oddity of their forms and for their large size. Humboldt mentions one growing on the banks of the Magdalena as having blossoms, measuring 4 feet in circumference, which the Indian children sportively draw on their heads as caps.

Several kinds of Aristolochia are cultivated 
in hothouses in England for the singularity and handsome appearance of their flowers, although their colours are by no means brilliant.

The flowers of various species act as flytraps. They are bent in the middle and are lined with hairs pointing downwards, so that ingress is easy, but escape impossible to the insect, which ultimately aids in the ripening of the seed.

The plant, especially the root, possesses many kinds of medicinal qualities, several of which could only be referred to in a medical work.

So satisfied are the natives of Mexico, Peru, and Central America of its extraordinary medicinal properties and specific virtues in cases of snake-bite, that every Indian or negro who has to traverse the country invariably has a supply of this friendly plant in a dry or prepared state, to meet any accident that may befall him from inadvertently placing his foot upon one of these dreaded and deadly foes of mankind. 


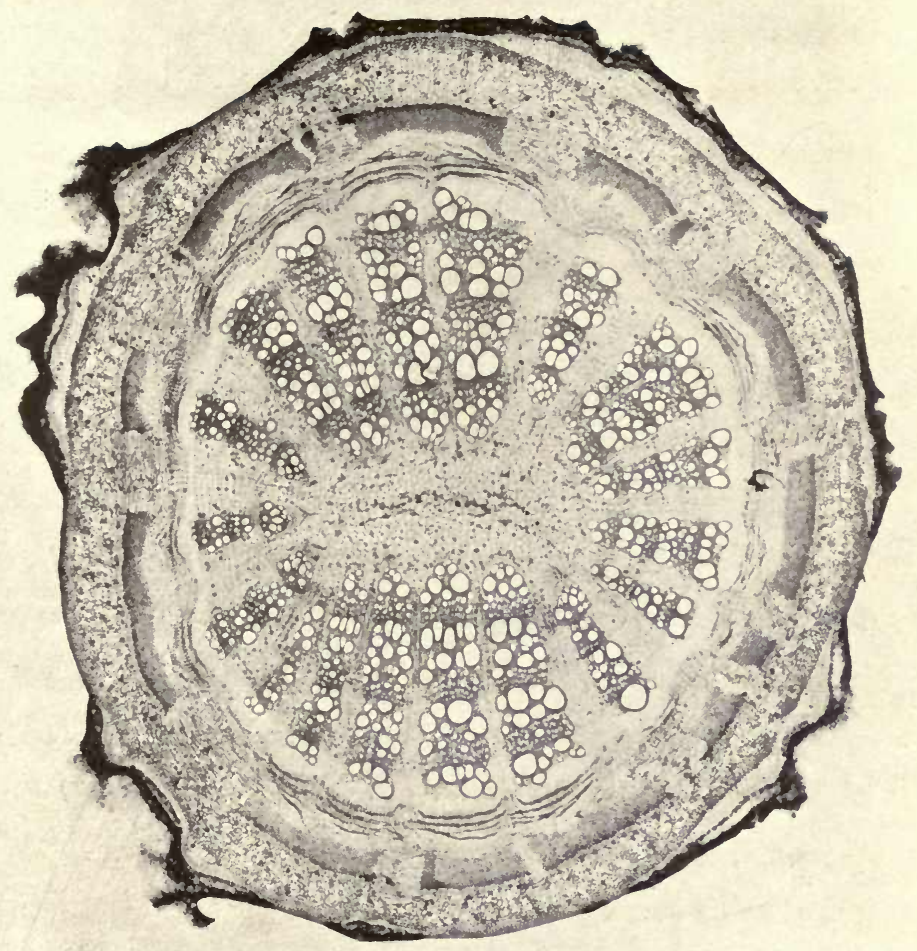

FIG. 37 .

STEM SECIION, ARISTOLOCHIA GIGAS.

$\times$ I4.

[to face page 128 . 

The illustration (Fig. 37) is taken from a photo-micrograph of 32 diameters; the time of exposure was 5 minutes; the focal distance was 48 inches; and the objective used was the inch and a half.

Looking more closely at the section we see certain dark portions at intervals on the margin; these are the bases of the leaves; next comes the bark; pointing towards the centre are radiating plates of wood with large air passages; between these and the bark are plates of wood running concentrically with the bark; these are held loosely together by soft, medullary processes. In the centre is the cellular pith.

This is an example of an aberrant exogenous stem.

\section{Calamus Rotang.}

The Calamus rotang is one of the chief species of palms that furnish the canes and rattans used in this and other countries for bottoms of chairs, couches, sides of carriages, and similar purposes. 
In the countries where these canes abound -the Malayan Peninsula and other parts of Asia-the natives use them for a great variety of purposes; baskets of all kinds, mats, hats, and other useful articles being commonly made of them.

Their most important use, however, is for the manufacture of ropes and cables usually employed by coasting vessels. In the Himalayas they are used in the formation of suspension bridges across rivers.

Dr. Hooker thus describes their construction: "Two parallel canes, on the same horizontal plane, were stretched across the stream; from these others hung in loops, and along the loops were laid one or two bamboo stems for flooring; cross-pieces below this flooring hung from the two upper canes, which they thus served to keep apart. The traveller grasps one of the canes in either hand and walks along the loose bamboos laid on the swinging loops.'

In the natural state the canes have reedlike stems, seldom more than an inch in 



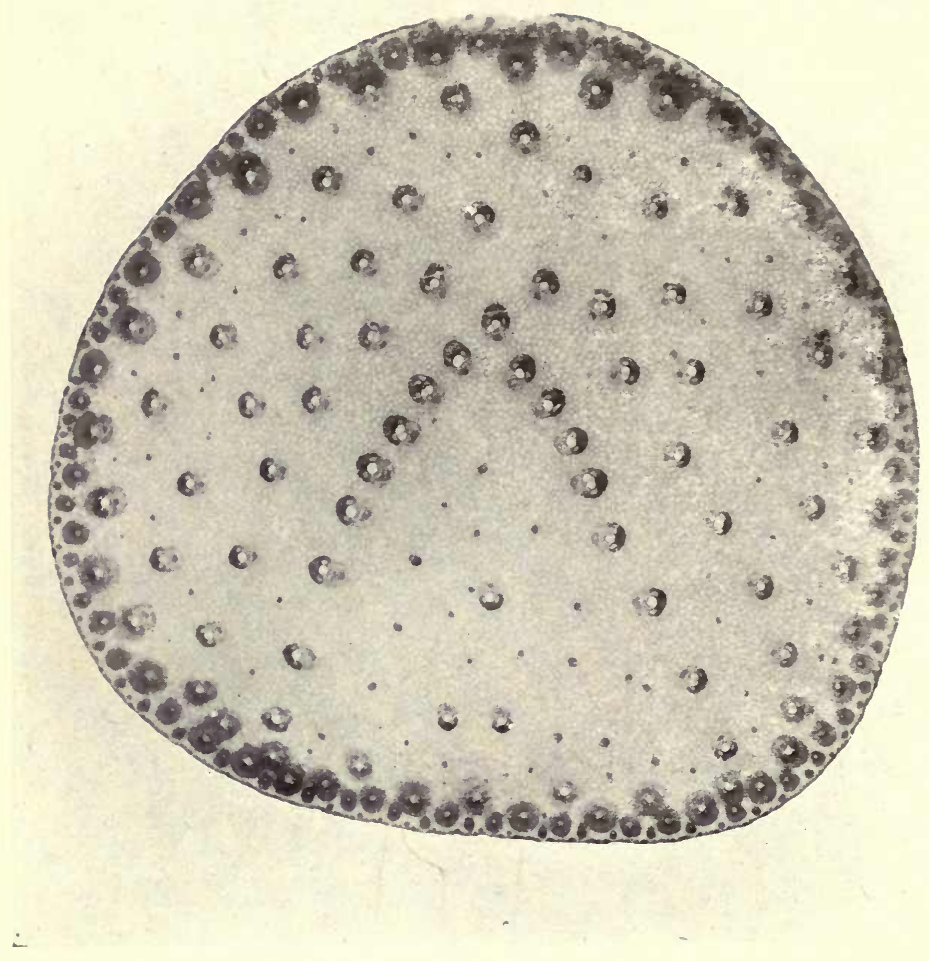

FIG. 33 .

STEW SECTION, RATTAN CANE (CAIAMUS ROTANG).

$\times$ I4

[to face page I31. 
thickness, but often much less, generally growing to a great length, climbing over and amongst the branches of trees. The stem has long internodes, the leaves being situated at some distance from one another. Sometimes in Ceylon and the Malay Islands the cane attains to the length of 300 feet. They fling, so to speak, their long shoots on the jungle and on the branches of trees, and hang there by means of their hooks.

The illustration (Fig. 38) is taken from a photo-micrograph of 30 diameters ; focal distance, 30 inches; the 1-inch objective was used.

The section shows the reed-like structure of the palm-Calamus rotang-an example of an endogenous stem without medullary rays.

Commencing at the outside, the outer hard, dense part consists of closely-packed epidermal cells. Next to this are vascular bundles right round within the margin; the smallest cells which predominate throughout the section are simply cellular tissue; the 
older part of the cane is next to the vascular bundles of the marginal series; then there are vascular bundles scattered about, each containing a large white cell, but those assuming the shape of the letter $\mathrm{V}$ enclose within their range the newer part of the cane. 


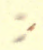

$\therefore$ 


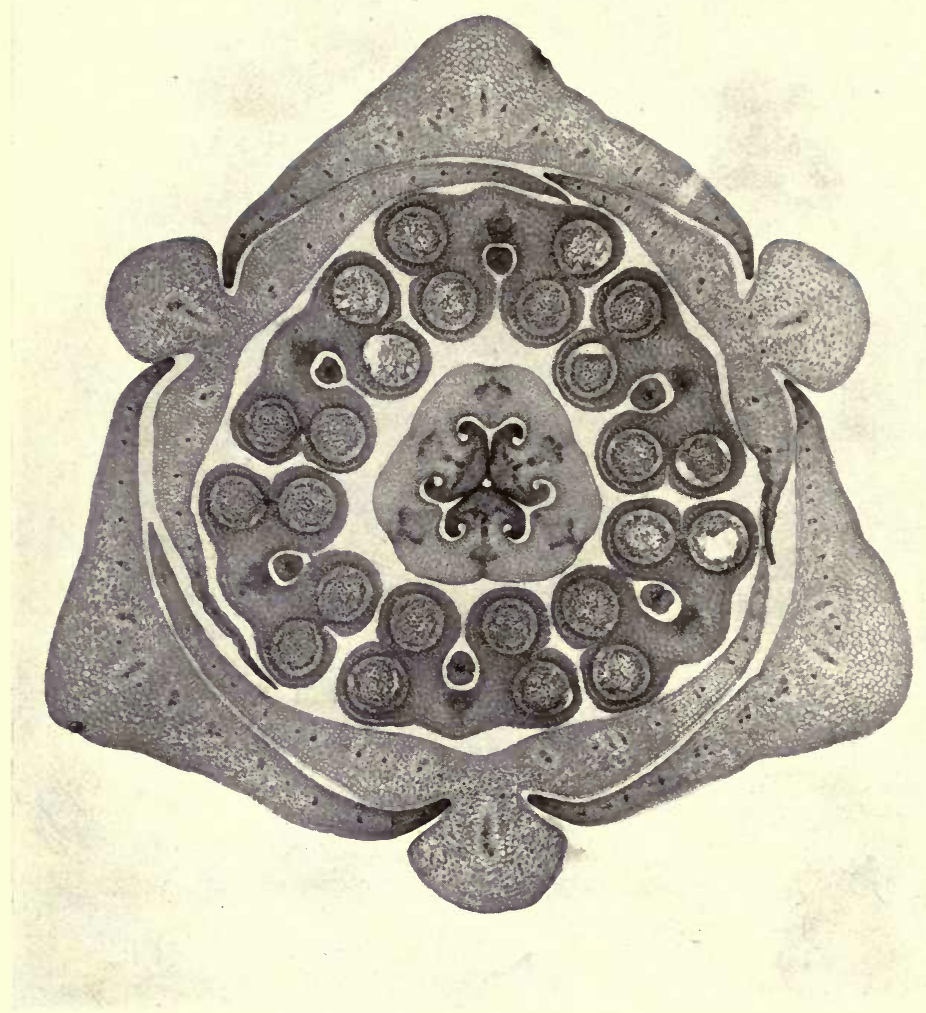

FIG. 39.

SECTION OF LILY BU!.

$\times 12$.

[to face page 133. 


\section{CHAPTER XII}

\section{BUD OF LILY, VIRGIN'S BOWER, AND PETIOLE OF NUPHAR LUTEA}

\section{Bud of Lily Section.}

F the lily itself no description is necessary. A glance at the section of its bud shows an amount of geometrical arrangement that is, in no small degree, surprising. Triangles, circles, hexagons, and even trapeziums find a place in its small dimensions. Minute cellular tissue is to be seen in all portions of its structure.

Beginning at the outside, we notice sections of six separate parts: these are the petals peculiar to all lilies. Each shows cellular tissue and fibro-vascular bundles. Then come six stamens, each containing a pair of two- 


\section{I34 BUD OF LILY AND CLEMATIS}

celled anthers which contain pollen. Each of the six stamens contains a filament. In the centre is a separate mass that could be enclosed in a six-sided figure. This is the ovary, but only the upper portion, without ovules.

The illustration (Fig. 39) is from a photomicrograph of 25 diameters; the focal distance was 50 inches; and the objective used was the 2-inch.

\section{Yirgin's Bower.}

(Clematis vitalba.)

The Clematideæ are well known for their ornamental plants. Almost all the genera have species which are cultivated for their great beauty. They are not endowed with sweet-scented flowers, neither have they the insect-loving honey. Still, the insects visit them for their pollen. The clematis is a twining shrub belonging to the Ranunculaceæ, among which they are known by their singlecoloured calyx without petals, and by the long feathery tail attached to their single-seeded carpels. 



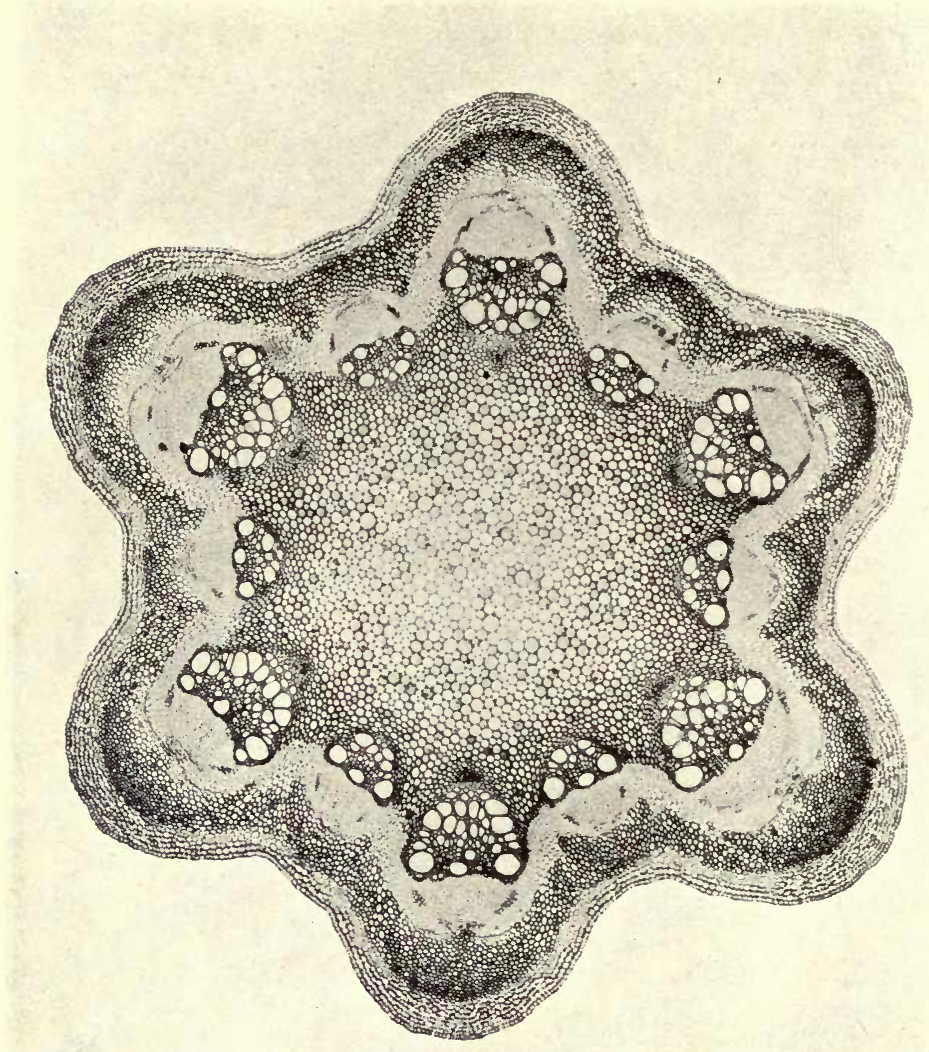

FIG. 40.

SECTION OF STEM OF EXOGEN (CLEMATIS VITALBA).

$\times 20$.

[to face page $\mathbf{1 3 5}$ 
Virgin's Bower is the only English species, and is so called on account of its being used for covering bowers. It is also known as Traveller's Joy, probably because of its being, in winter, among the most conspicuous and ornamental of wayside plants, often covering hedges for a considerable distance with its feathery seed-vessels. The flowers are greenishwhite, and, as already stated, they are destitute of perfume.

From the feathery appearance of the seedvessels, resembling grey hair, the plant is sometimes known by a third name, Old Man's Beard.

The section shows the vine-like herbaceous or woody stem of Clematis vitalba. Beginning at the centre, we have the cellular tissue of the pith; then the fibro-vascular bundles with air cells. Around the margin is the beautiful structure of the cortical parenchyma.

The illustration (Fig. 40) is from a photomicrograph of 40 diameters; the focal distance was 36 inches; and the objective used was the 1-inch. 
Many climbing plants have sensitive tendrils by means of which they cling to their supports, but in the clematis, instead of separate special organs, the clinging powers are embodied in the long, thin stalks of the leaves themselves, which wind round their supports.

\section{Petiole of Nuphar Lutea.}

The Nuphar lutea, or common yellow waterlily, and the Nymphaca alba, or great white water-lily, have the same generic characters. The calyx consists of five or six leaves, the petals are numerous and small, and there are stamens on the seed-vessels.

These two plants are generally to be found on lakes and ponds, in parks and gardens. The white water-lily is found frequently in lakes and still waters in Scotland, and the yellow is common in most rivers and lakes. The country people call the yellow water-lily 'Brandy-bottle,' as it smells like brandy.

The petals are usually thirteen in number, and form a continuous spiral with the stamens. 


\section{STRUCTURE AND USES OF PLANT I37}

The Victoria regia, a Brazilian species, has peltate leaves of more than a yard in diameter. Both the Nuphar lutea and the Victoria regia can effect self-fertilisation.

The fruit, which rests on the water, becoming detached from its stalk and dehiscing from the base upwards, effects the dissemination of the seeds.

The section of the petiole shows the stellate hairs at intervals. Some are transparent and difficult to see.

The root-stocks bruised and infused in milk are said to be destructive to cockroaches, and when burnt to be particularly obnoxious to crickets. The flowers are used by the Turks in the preparation of cooling drinks, like sherbet.

The seeds, as they contain a quantity of starch, are used in some countries as food. The root-stalks and flower-stalks are traversed by a great number of air canals, the arrangement of which is the same in both organs.

In the illustration (Fig. 41) the large open ings are transverse sections of the largest inter- 
cellular spaces bounded by simple layers of cells. The stellate idioblasts can be seen. The dark patches are fibro-vascular bundles.

The original photo-micrograph shows an amplification of 20 diameters; the focal distance was 40 inches; and the objective was the 2-inch.

'In the water-lily the subsequent flat leaves are, when in the bud state, rolled together, either each individual leaf by itself, or so that the young leaves envelope one another. On subsequent growth the rolled-up margins are drawn apart and the leaves become extended flat.

'Now as long as the young leaves remain in this rolled-up condition in the bud-state they are said to be orthotropic, because they constitute a radial convolute structure. But as soon as they extend themselves they become plagiotropic, and are placed obliquely or horizontally with reference to gravitation and extended at right angles with respect to the rays of light.' (Sachs.) 


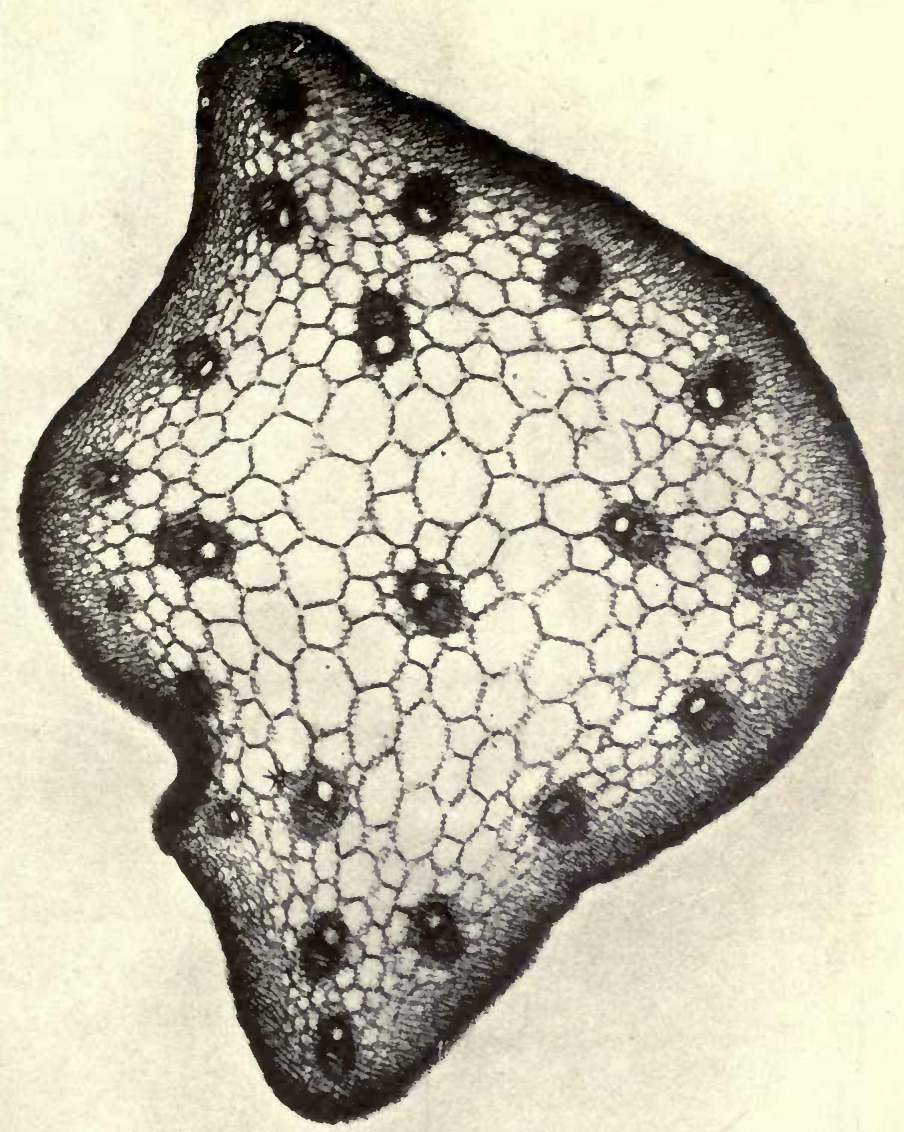

FIG. 4 I.

TRANSVERSE SECTION OF PIANT STEM (NUPHAR LUTEA).

$\times I 2$.

[10 face parge 138 . 



\section{CHAPTER XIII}

\section{SPRUCE FIR, BUTCHERS' BROOM, AND HIPPURIS VULGARIS}

\section{Spruce Fir Section.}

THE Spruce Firs are by some botanists 1 known as Picea, and are a sub-genus of the Conifera. Sometimes they are included with the Silver Firs in Abies.

The firs are for the most part lofty trees, with small narrow evergreen leaves placed in two rows along the sides of the branches, or occasionally tufted.

The cone, which is usually of a cylindrical form, consists of a number of woody scales which overlap each other, but are not thickened at their points as are the scales of pine cones. 
This species of fir supplies fine timber trees and yields turpentine and several substances valued by the chemist.

The Spruce Fir so common in Norway, Russia, and the mountainous parts of Europe generally, is known as Abies excelsa. It is a handsome tree, and often rises to a height of $\mathbf{1 5 0}$ feet. The leaves are dull green, four-cornered, and sharply pointed. The cones are cylindrical, with scales that are slightly waved or toothed. These trees thrive best on a damp soil. The timber is much used and known as white deal. From the trunks issues a resin commonly called frankincense, which when melted in water and strained constitutes Burgundy pitch.

The Silver Fir, sometimes called Abies picea, receives its name from the fact that its leaves are whitish on their under sides. They are arranged in two rows, and have their points turned upwards. The cones are erect, of a greenish-purple colour, with scales provided with long tapering bracts on their outer surface. The beauty of this tree is such that Virgil has 


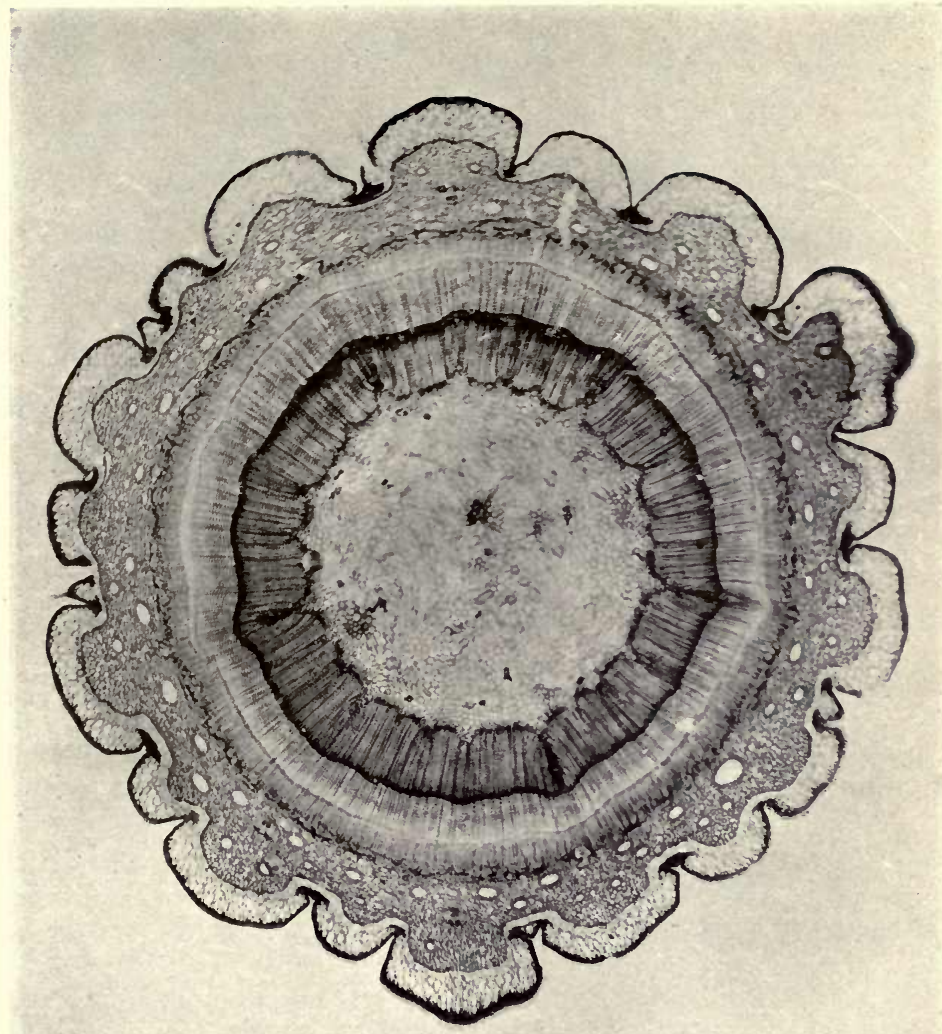

FIG. 42.

SPRUCE FIR, STEM SECTION,

$\times 15$.

[To face page 140. 

applied to it the epithet 'pulcherrima,' 'very beautiful.' It attains a height of 100 feet and upwards, and is a native of Central Europe and Northern Asia.

Its timber is not so much prized as that of some other species, but has the great advantage of being durable under water.

From its bark exudes a resin, which when purified is known as ' Strassburg Turpentine.'

The illustration (Fig. 42) is taken from a photo-micrograph of 32 diameters; the focal distance was 32 inches; and the objective used was the 1-inch.

It represents a section across a twig of the Norway Spruce, Abies excelsa.

Commencing at the outside edge we see the thick cortical cells; next we have the cellular tissue with air cells, or air spaces; these lie immediately under the cortical cells; in the third layer we observe white spaces at intervals in cellular tissue, these are resin canals; further towards the centre and radiating in marvellously beautiful lines closely packed together, are the woody fibrous vessels; inside 
these and forming the centre of the twig are the cells of the interior.

\section{Butche: s' Broom.}

Butchers' Broom (Ruscus aculeatus) is generally found in a gravelly soil in the South of England, where it favours woods more than the open country. It is a handsome plant, and especially so in the winter, when its bright scarlet berries are matured.

It is prized as a Christmas decoration, and retains its freshness longer than the holly.

It is a shrublike plant with thick white roots, which send up a number of stems that grow to a height of some 2 or 3 feet.

Each stem has many ovate, sharp-pointed, dark green leaves. The flower appears on the upper surface of the leaf. The position of the flower and berry in the centre of the leaf renders this plant very peculiar, and shows another instance of the wonderful variety there is in Nature.

Ruscus androgynus, a native of the Canaries, 


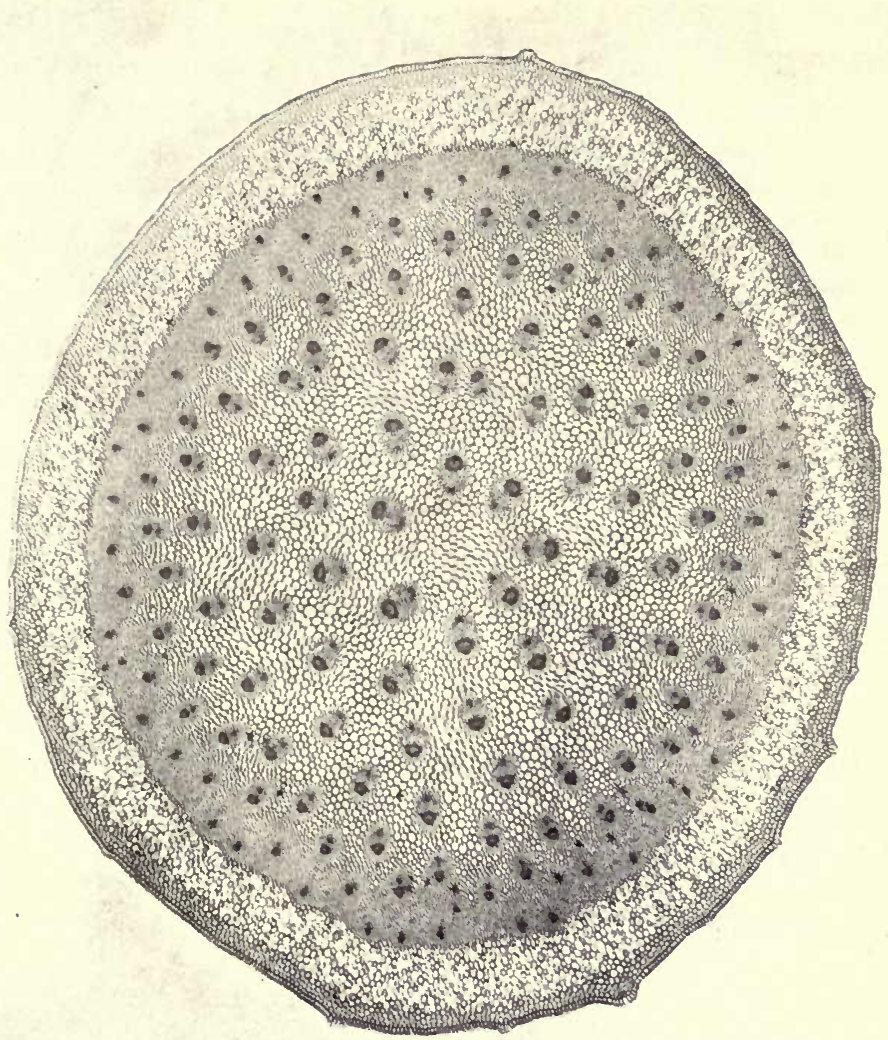

FIG. 43.

SECTION OF STEM OF BUTCHERS' BROOM

$\times 2$.

[to face page it 2 . 



\section{HOW DESCRIBED BY BOTANISTS I43}

bears its flowers along the edges of the leaves, and in Ruscus hypophyllum the flowers are borne on the under side of the flattened branches.

The young shoots of the English Butchers' Broom are eaten like those of asparagus, and the mature plants are made into brooms. The plant is one of the Asparageæ. Belonging to the same sub-order are Asparagus, Lily of the Valley, Solomon's Seal, Herb Paris, which is poisonous, Wood Lily, and Parlour Palm.

Recognised authorities on botanical subjects, in a few words, express a great deal. In Warming and Potter's Systematic Botany the Butchers' Broom is described as follows :- ' Is a South European shrub with leaf-like ovoid or elliptical shoots, which are borne in the axils of scale-like leaves, and bear flowers in the central line. Diœcious, stamens 3, united, anthers extrose.'

On referring to the Student's Text Book of Botany, by S. H. Vines, I find the plant described as follows:-'Small shrub, with leaf- 
like branches on which the declinous flowers are borne in the axils of minute leaves.'

The photograph from which the illustration (Fig. 43) was taken shows an amplification of 40 diameters. The focal distance was 62 inches; the exposure 4 minutes. A yellow screen and a $1 \frac{1}{2}$-inch objective were used.

Beginning at the outer margin of the section we have the epidermal cells; close to these we see the bark cells; then loose cellular tissue with air passages; all the remaining portion consists of cellular tissue containing at intervals the fibro-vascular bundles. The cells at the centre are the new growth.

\section{Hippuris vulgaris.}

The Mare's-tail grows wholly or partially submersed in ditches or canals. It sends up from its creeping roots numerous unbranched erect stems, having at short intervals whorls of linear leaves. In the axils of the leaves are small inconspicuous flowers, each of which 



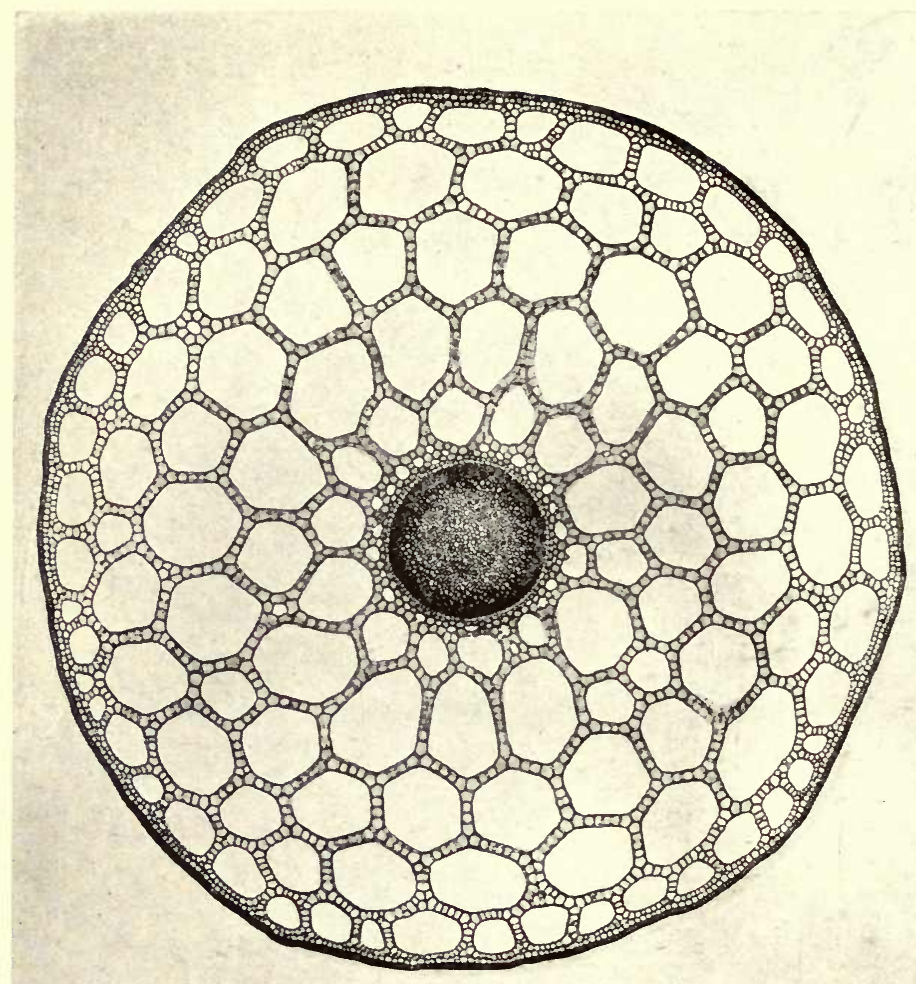

FIG. 44.

STEM OF SECTION OF MARE'S TAIL (HIPPURIS VULGARIS)

$\times 14$

[to face page 145 . 
contains a single stamen but no petals, and an ovary with a single seed.

'There are two or three species, only one of which is to be found in these islands. It is so unlike any other plant, except perhaps Equisetum (the Horse-tail), that it is easily recognised. The branches in the Equisetum are jointed, while the narrow verticellate leaves are continuous throughout. There is some resemblance in habit between the Hippuris and the Equisetum, but in all essential characters they are perfectly distinct. So far the plant has not been found of any special importance in medicine or the arts, but to the microscopist sections of its stems are of great interest. The beautiful arrangement of the multitude of cells must always command attention and admiration.' (Sachs.)

The illustration (Fig 44) is taken from a photograph showing an amplification of 32 diameters; the focal distance was 50 inches; and the objective used was the 2-inch.

Beginning at the centre of the section, we see the pith surrounded by a cylinder of fibro- 
vascular tissue. Outside this cylinder and close to it are cellular tissues and air passages. Next we have large intercellular spaces, their walls consisting of cellular tissue. At the margin immediately on the inside is cellular tissue, while the external part consists of thick epidermal cells. 


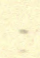

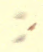




\section{CHAPTER XIV}

\section{HUMAN HAIR}

A SINGLE human hair is by no means an A elementary structure. It is surprising what an amount of physiological detail it contains. There seems to be as much care and skill expended upon it and all its parts, and they are many, as upon a limb or any of the great vital organs of the body.

In its immediate composition there are nine or ten different layers in addition to its muscles, glands, and blood vessels. If added to all this we were to look at a single hair histologically, and see the various cells as they are arranged in cuticle, shaft, Huxley's layer, Henle's layer, and cortex of root, we should be inclined to think we were examining a much larger and 
more important matter than a single hair. Suppose out of mere curiosity we look more closely at some of the properties and the composition of a hair.

First, then, the hair has considerable elasticity. 'It will stretch 33 of its length. It has great powers of cohesion, for a single healthy hair will carry from 3 to $5 \mathrm{lbs}$. It will resist putrefaction for a long time. There are many proofs of this remarkable property. It is highly hygroscopic,'* as it readily detects damp in the atmosphere. It is also capable of displaying electrical effects in dry, frosty weather. Ladies know this when brushing the hair. In some of the lower animals hairs possess an additional property; they are feelers and real organs of touch.

'As regards the chemical composition of hair, it contains alkaline sulphates, calcium sulphates, iron oxide, and salicic acid. Dark hairs yield more iron than blonde hairs. The black or brown colour of hair in general is due

* Text-Book of Human Physiology. Landois and Stirling. (C. Griffin \& Co.) 



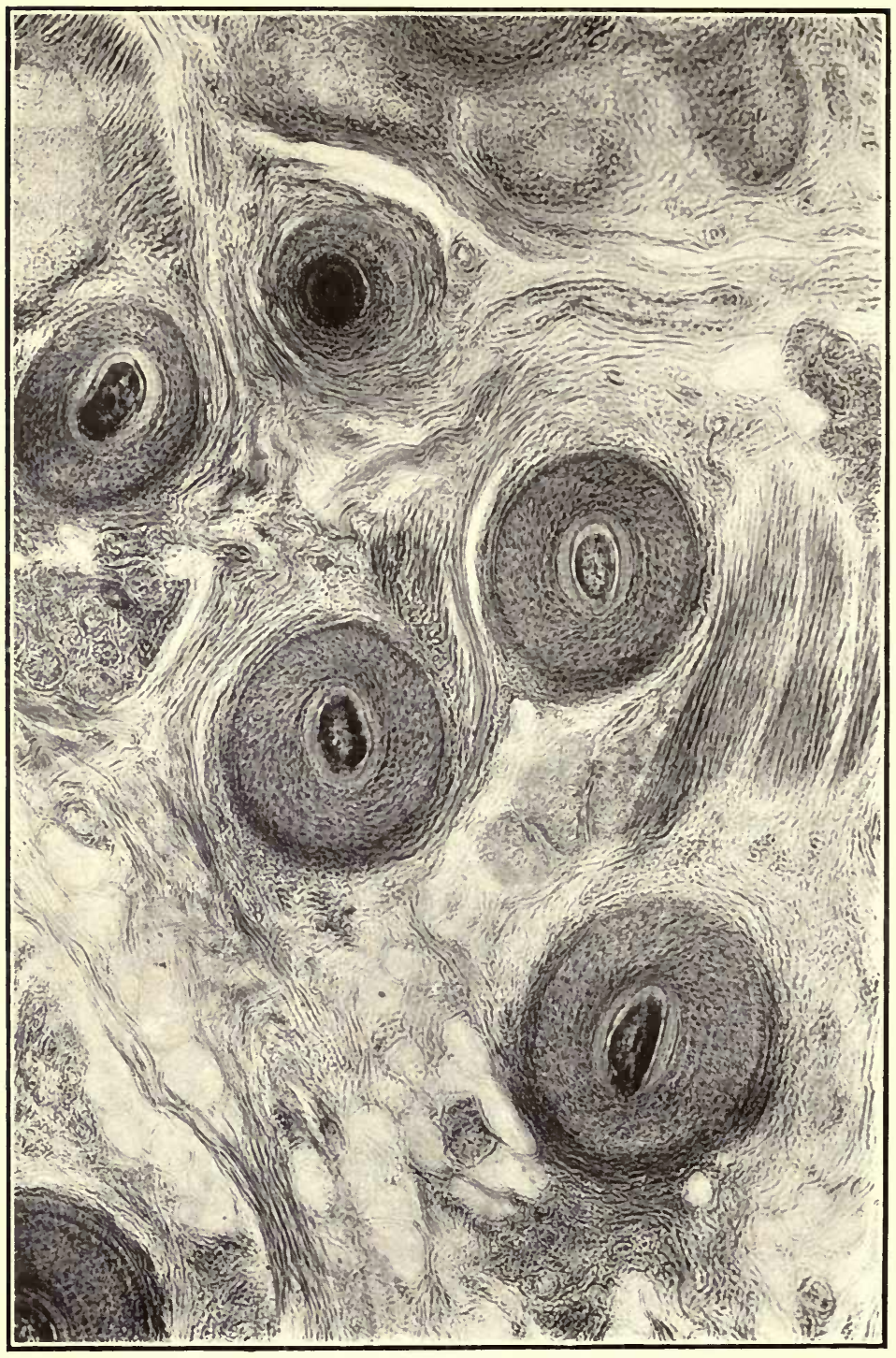

FIG. 46 .

TRANSVERSE, SECTION OF HUMAN SCALP. 
to melanin. There seem to be several varieties of this pigment. Compared with the hairs of other animals the melanin of the human hair contains less nitrogen and more sulphur.'*

As to the physiological composition of a single hair, we have the medulla in centre; this is surrounded by the cortex; next in order is the cuticle, then Huxley's layer; Henle's layer is next; then we have the external root sheath; next in order is the homogeneous layer; outside this the layer of circular fibres; and next the layer of horizontal fibres. The three latter make up the connective tissue portion of the hair follicle. $t$

We have roughly enumerated merely the main facts connected with the component parts of a hair; and although we have omitted the relative functions of all these parts, we must agree that a hair is a most wonderful structure.

But we have not yet done justice to the hair.

* Text-Book of Human Physiology. Landois and Stirling. (C. Griffin \& Co.)

+Text-Book of Physiology. McKendrick. (J. Maclehose \& Sons.) 
We should look at it from another standpoint. " "The part projecting from the skin" is the shaft, or scapus; the part passing obliquely into the skin is the root, or radix pili; and at the end of the root is the bulb, bulbus pili, having a hollow underneath filled with a tissue belonging to the corium, and termed the papilla. The root is surrounded by a modified portion of skin termed the follicle, in the formation of which are found both corium and epidermis. The epidermal portion forms the sheath or sheaths. From two to five glands open into the follicle, termed sebaceous glands. A few bundles of plain, smooth, muscular fibre pass obliquely from the side of the follicle to the under surface of the corium. These constitute the erector muscle of the hair-musculus arrector pili. When they contract towards the corium they pull on the sheath and erect the hair.'*

The cuticle is formed of tile-shaped hard cells, the edges of which sometimes project from the surface of the hair. If a hair be

* Text-Book of Physiology. McKendrick. (J. Maclehose \& Sons.) 
rolled between the finger and thumb, it will pass along invariably in one direction, showing that the cells are arranged to face one way. If a hair be drawn along the lips one way and then in the opposite direction, a difference will readily be detected.

In the hair of certain lower animals, when this imbricated arrangement of the cells is more pronounced, the hairs are better adapted to the process of felting.

On referring to the illustrations, Fig. 45 shows a vertical section of the human scalp. Several hairs or portions of hair are seen in situ. The original photograph is one of 26 diameters. The time of exposure was 2 minutes; the focal distance was 39 inches; and the objective used was the $1 \frac{1}{2}$-inch without the eye-piece. The next illustration (Fig. 46) is from a photomicrograph of 100 diameters. It shows the transverse sections of several hairs, also sweat glands and erector muscles besides several other histological details; the focal distance was 50 inches, and the objective used was the $\frac{1}{2}$-inch. 


\section{CHAPTER XV}

\section{HUMAN SKIN, HEART MUSCLE, AND HUMAN BONE}

\section{Human Skin.}

' $П \mathrm{HE}$ skin consists chiefly of the exterior epithelium, called also cuticle or epidermis, and the corium, derma, or Cutis vera.

'Below the corium are embedded several organs with special functions, namely, the sudoriferous glands, sebaceous glands, and hair follicles. On the surface of the skin are sensitive papillæ.

'The so-called appendages of the skin-the hair and nails-are special modifications of the epidermis.

' The epidermis, or epithelium, which covers the true skin, is composed of several strata of 
various shapes. Four of these layers are distinguishable.

'First.-The Stratum corneum, which consists of many layers of horny scales. The different thickness of the epidermis in different regions of the body is chiefly due to variations in the thickness of this layer, e.g., on the horny parts of the palm of the hand and soles of the feet it is of great thickness.

'Second.-The Stratum lucidum, a bright homogeneous membrane, consisting of squamous cells, closely arranged, in some of which a nucleus can be seen.

'Third.-The Stratum granulosum, consisting of one layer of flattened cells, which are distinctly nucleated. A number of granules extend from the nucleus to the margins of the cells.

' Fourth.-The Rete mucosum, which consists of many strata. The deeper cells are columnar with oval nuclei, then follow several layers with spherical nuclei. The deeper surface of the Rete mucosum is accurately adapted to the papillæ of the true skin, being, as it were, 
moulded on them. This layer is of constant uniform thickness in all parts of the skin. The pigment of the skin, the varying quantities of which cause the various tints observed in different individuals and different races, is contained in the deeper cells of the Rete тисовит.

'It is a most remarkable fact that the epidermis maintains its thickness in spite of the constant wear and tear to which it is subjected.'

\section{How the Outer Skin is removed.}

The explanation of this is as follows:'The columnar cells of the Rete mucosum elongate, and their nuclei divide into two; the upper part of each cell separates from the lower; thus from a long-columnal cell are produced a polyhedral and a short columnar cell. The latter elongates and the process is repeated.

'The polyhedral cells thus formed are pushed up towards the free surface by the production

* Kirkes, Handbook of Physiology. Morranł Baker's Edition. (John Murray.) 
of fresh ones beneath them, and become flattened by pressure; they also become gradually horny by evaporation and transformation of their protoplasm into keratin, till at last by rubbing they are detached at the surface as dry, horny scales. There is thus a constant production of fresh cells in the deeper layers, and a constant throwing off of the old ones from the free surface. When these two processes are accurately balanced the epidermis maintains its uniform thickness. When by intermittent pressure a more active cell-growth is stimulated, the production of cells exceeds their waste, and the epidermis increases in thickness, as we see in the horny hands of the labourer.

'The Cutis vera.-The corium, or cortis, which rests upon a layer of adipose or cellular tissue of varying thickness, is a dense and tough, but yielding and highly elastic structure. It is composed of fibro-cellular tissue, interwoven in all directions, and forming by their interlacement numerous spaces or areolæ.

' The Papilla, are conical elevations of the 
corium, each with a single or divided free extremity, more prominent or more densely set at some parts than at others. Most abundant, for example, on the palmar surface of the hand and fingers and the soles of the feet, where, therefore, the sense of touch is greatest.

- Each papilla is abundantly supplied with blood, receiving from the vascular plexus in the cutis one or two tiny arteries which divide into capillary loops in its substance, and then re-unite into a minute vein which passes at its base.

' The nerve terminations and many other important points about the skin cannot be noticed here, but it is necessary that even a brief reference should be made to the

\section{Functions of the Skin.}

'(1) As an external integument for the protection of deeper tissues.

'(2) As a sensitive organ in the sense of touch.

'(3) An important excretory organ, e.g., perspiration, \&c. 


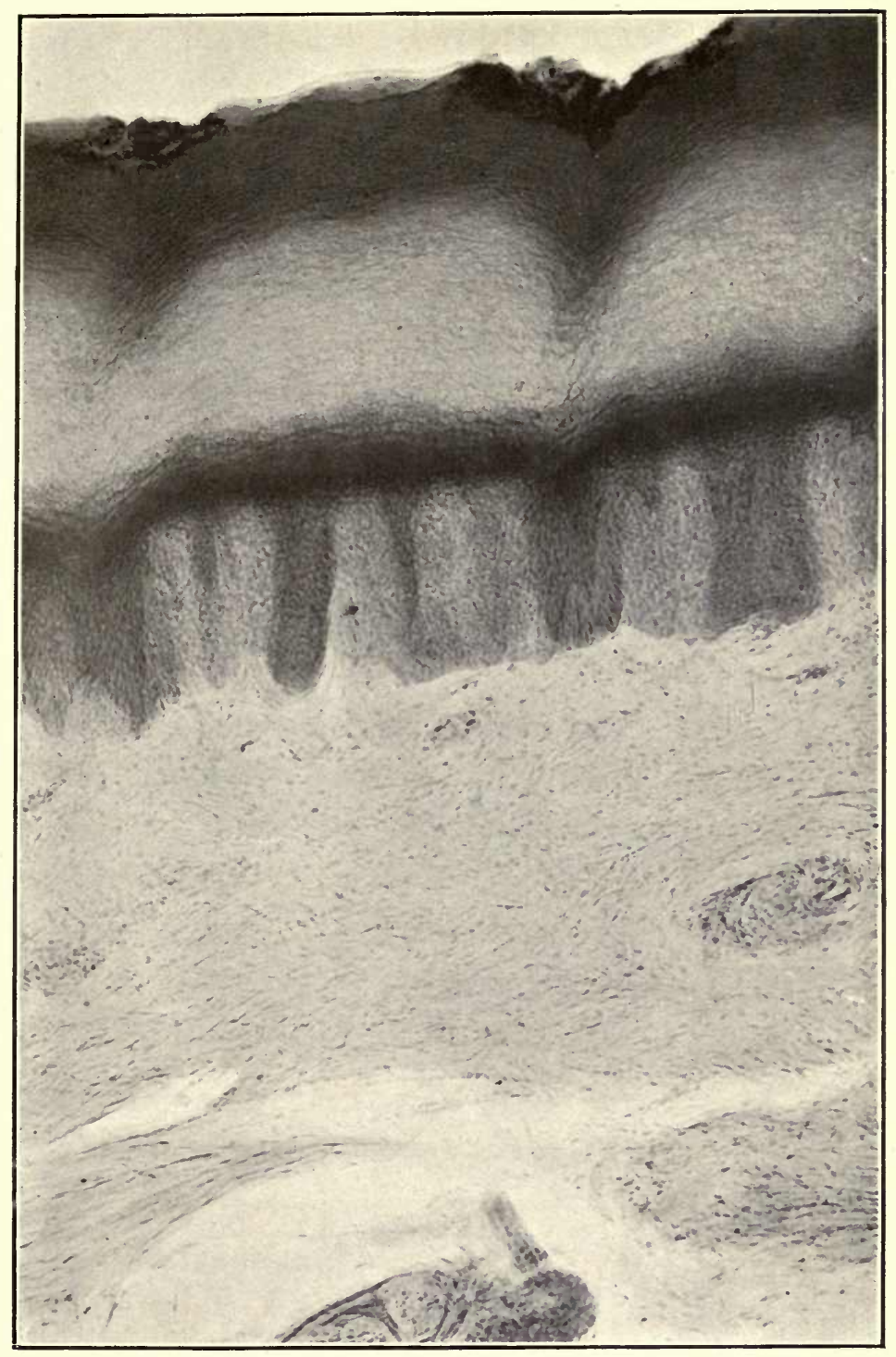

FIG. 47.

HUMAN SKIN, VERTICAL SECTION,

$\times 100$. 
'(4) An absorbing organ.

'(5) It plays an important part in the regulation of the temperature of the body."*

The illustration (Fig. 47) is taken from a photo-micrograph showing an amplification of 100 diameters of the vertical section: the focal distance was 50 inches; and the objective used was the $\frac{1}{2}$-inch.

\section{Heart Muscle (Human).}

The structure of the human heart is marvellous in every microscopic detail. It must be so in order to do the incessant and gigantic work it does. Throughout life it never ceases for rest, day or night. It is a wonderful and startling thought that for 60,70 , or even 100 years it continues its rhythmical beats, pumping the vital fluid through the complex human system of arteries, capillaries, and veins. If it were to take a single halfhour's rest we should die.

* Kirkes, Handbook of Physiology. Morrant Baker's Edition. (John Murray.) 
In order to place before our readers a concrete idea of the amount of work done in a given time by the heart, we have consulted the calculations of seven great medical authorities, and in a very brief form we append a summary of results :-

Two of the number, after entering into mathematical estimates, came to the conclusion that the heart in one day of eight hours does about one-quarter of the work done by a.labouring man during the same time, assuming that the workman works honestly. (Dr. Waller.)

Another authority calculates the work done per day by a horse and the work done. in the same time by the human heart, and, omitting the details of his calculations, he finds that the work of the heart equals $\frac{1}{75}$ th that of the horse. (Dr. Hales.)

A fourth medical writer calculates that the total work of the heart in twenty-four hours is about 124 foot-tons. (Dr. Haughton.)

Three other medical experts agree in the manner of ascertaining the work of the heart, 


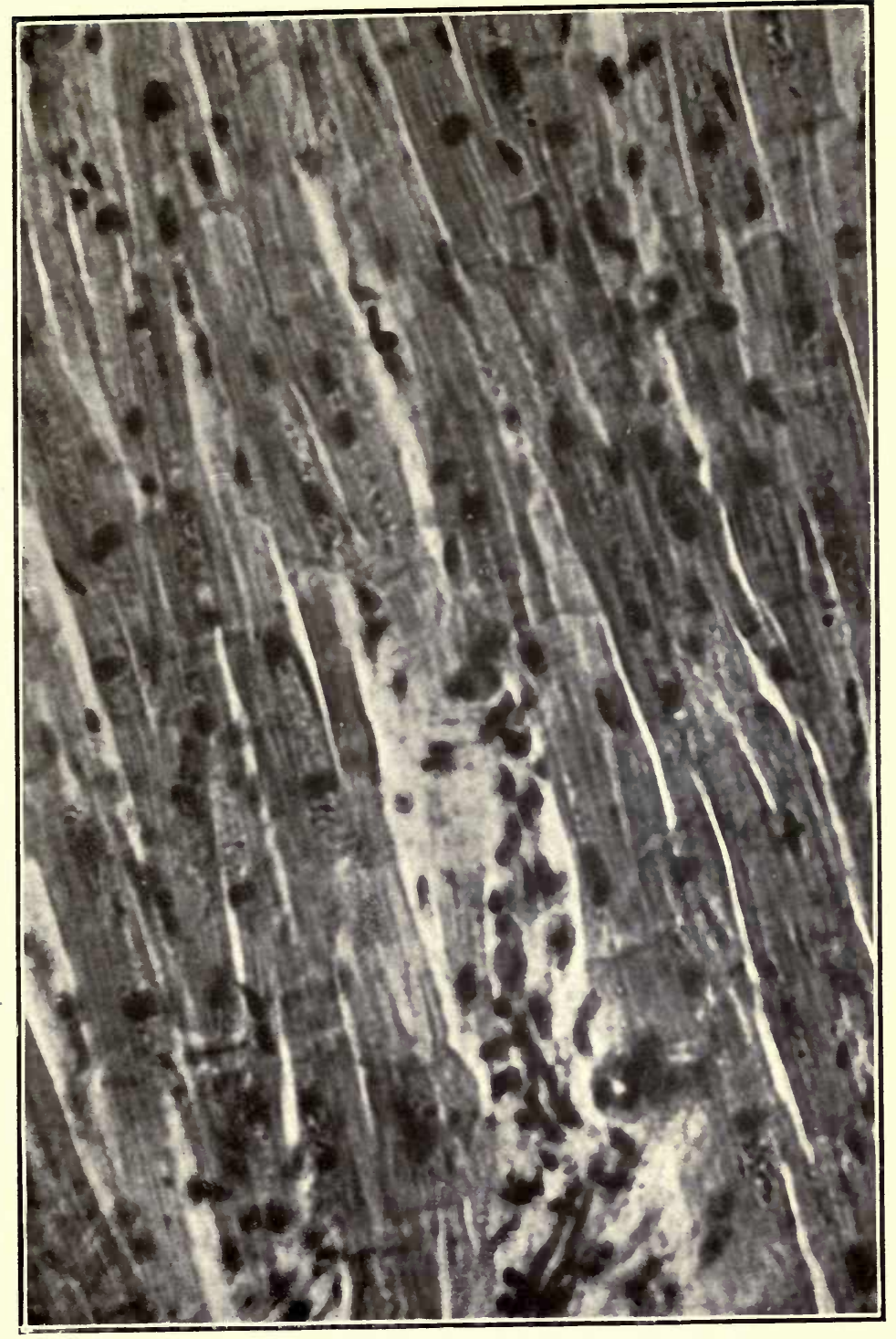

FIG. 48 . 

and their results are almost identical. The following is an outline that may bring the matter clearly before us, while it ought to make us value the mechanical achievements of our hearts and the magnificence of the structure capable of such heary work:-

'In estimating the amount of work done by any machine it is usual to express it in terms of "unit of work." The "unit of work" is defined to be the energy expended in raising a unit of weight (1 lb.) through a unit of height (one foot). In England the "unit of work" is the "foot-pound." The work done by the heart at each contraction can be readily found by multiplying the weight of the blood expelled by the ventricles by the height to which the blood rises in a tube tied to an artery. This height has been found to be about 9 feet in the horse, and it has been shown that this estimate is nearly correct for a large artery in man.

'Taking the weight of blood expelled from the left ventricle at each systole as 4 ozs., that is, $\frac{1}{4}$ lb., we have $9 \times \frac{1}{4}=2 \frac{1}{4}$ foot-pounds 
as the work done by the left ventricle at each systole; and adding to this the work done by the right ventricle (about a third that of the left) we have $2 \frac{1}{4}+\frac{3}{4}=3$ foot-pounds as the work done by the heart at each contraction.'*

In the illustration we see only an exceedingly small portion of the muscular structure of this most wonderful organ (Fig. 48). Its fibres are visible; they are columnar and faintly striated; the nuclei are distinctly seen. Each fibre is branched, and there is no covering.

The original photo-micrograph shows an amplification of 550 diameters : the time of exposure to gaslight was 5 minutes; the focal distance was 72 inches; and the objective used was the $\frac{1}{2}$-inch; the eye-piece of 5 diameters was also used.

\section{Human Bone.}

Speaking generally, bone seems to have three distinct duties-it gives support and firmness

* Kirkes, Handbook of Physiology. Morrant Baker's Edition. (John Murray.) 


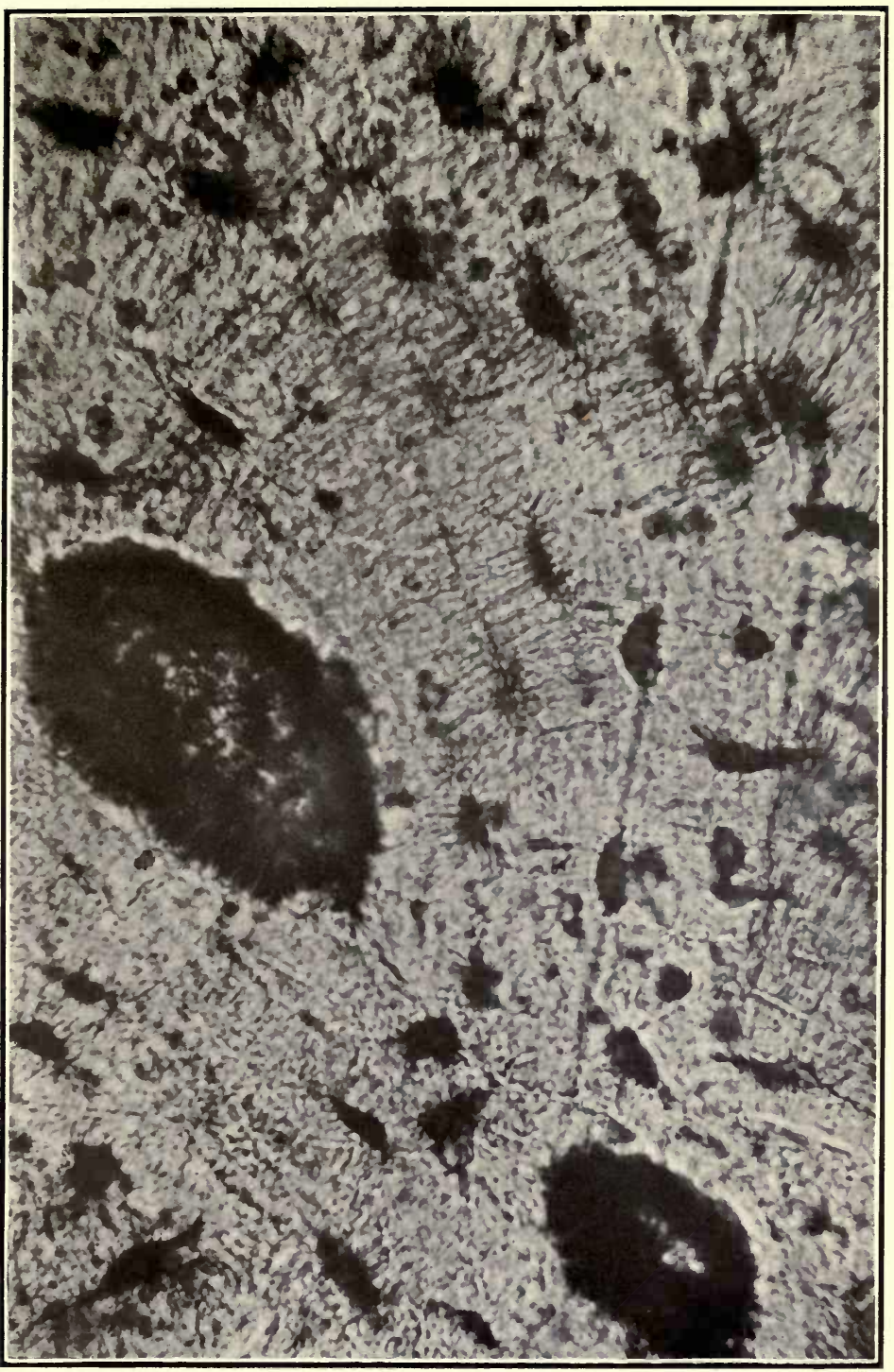

FIG. 49 .

TRANSVERSE SECTION OF HUMAN BONE, 

to the bodies of all members of the vertebrate kingdom; it protects many delicate organs; and it affords points of attachment for muscles.

On examining a thin transverse section of human bone under the microscope with a low power it is found to exhibit a number of round or oval apertures. These are transverse sections of the Haversian canals. Each Haversian canal contains an artery, vein, nerve, and lymphatic vessels, all for nourishing the bone. They mostly run parallel with the axis in long bones, but in flat bones they are parallel to the surfaces.

Still keeping to our transverse section, but using a higher power in the microscope, we find it exhibits numerous dark spots with fine lines branching from them in all directions. The dark spots are the lacunæ, and the fine lines branching from them are the canaliculæ, or calcigerous canals. The dark appearance of both lacunæ and canaliculæ is owing, in dried bone, to the air they contain.

If the air be removed by immersion in oil of turpentine they become white or 
transparent, according to the position of the light.

In a transverse section of bone, the lacunæ of the layer surrounding the Haversian canals are seen to be placed tangentially to the orifices of these canals, whilst those of the layer near the surfaces of the bone run parallel with those surfaces.

A Haversian system, consisting of a $\mathrm{Ha}$ versian canal, its lacunæ, and all the canaliculæ that communicate with that same canal, is complete in itself, and entirely independent of other Haversian systems.

Chemically, bone consists of gelatine with phosphate of lime and magnesia, small quantities of carbonate of lime, carbonate of magnesia, fluoride of calcium, and a little oxide of iron and magnesia.

The photo-micrograph from which the illustration (Fig. 49) was taken shows an amplification of 550 diameters-the Haversian canals appearing as large as chestnuts; the objective used was the one-sixth, and the focal distance was 78 inches. 



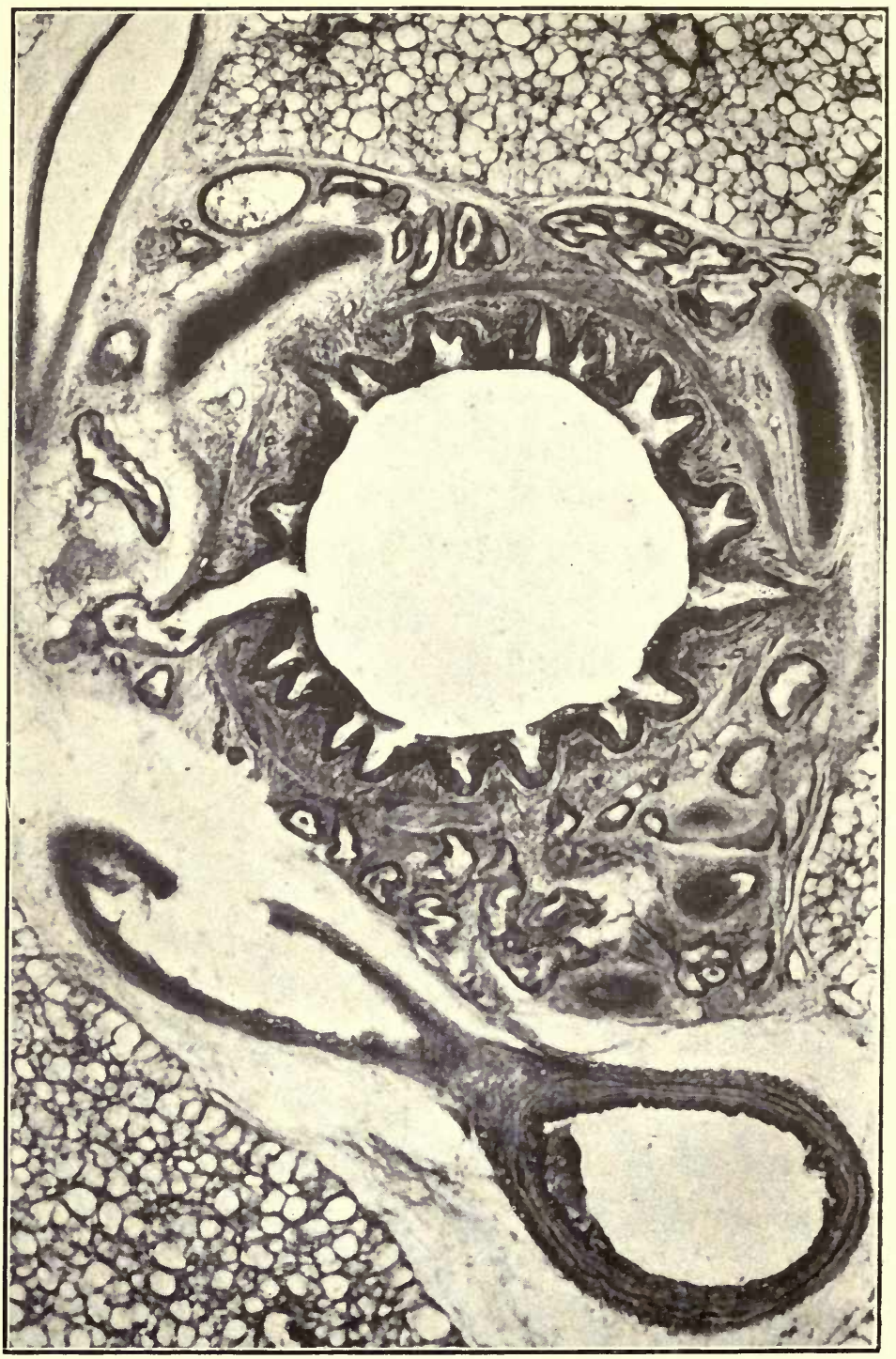

FIG. 5 O.

SECTION OF HUMAN I.UNG. 


\section{CHAPTER XVI}

\section{HUMAN LUNG, RED CORPUSCLES OF THE BLOOD, AND HUMAN TOOTH}

\section{Human Lung.}

AERY tiny portion of the human lung $A$ is shown in Fig. 50. The section is taken transversely through a small bronchus which appears in the illustration as the largest of the openings. Connected with it is a mucous gland. Sections of an artery and a vein can be seen near the bronchus.

Four or five smaller openings, having a starlike structure, are bronchioles (air tubes). Near the bronchus, but lying on the side opposite the mucous gland, are two curved, dark objects. These are sections through two portions of cartilage. 


\section{I64 HUMAN LUNG : RED CORPUSCLES}

The tiniest openings, of which many hundreds are visible, are the lung alveoli, or air cells. It is in these that the blood is aerated. Their walls are comprised of a network of blood vessels.

The original photo-micrograph (Fig. 50) showed an amplification of 20 diameters; the focal distance was 60 inches; and the objective used was the 3-inch.

\section{Red Corpuscles.}

Although to the naked eye the blood seems uniformly tinted, it is found by the microscope to be really an almost colourless fluid, containing minute coloured cells which contain the hæmoglobin or red colouring matter of the blood. Even in thin layers the blood is opaque, on account of the different refractive powers of the corpuscles and the plasma in which they are suspended.

In man, and in all mammals except the Camelidæ, the form of the coloured corpuscles is that of a bi-concave disc. In the Came- 


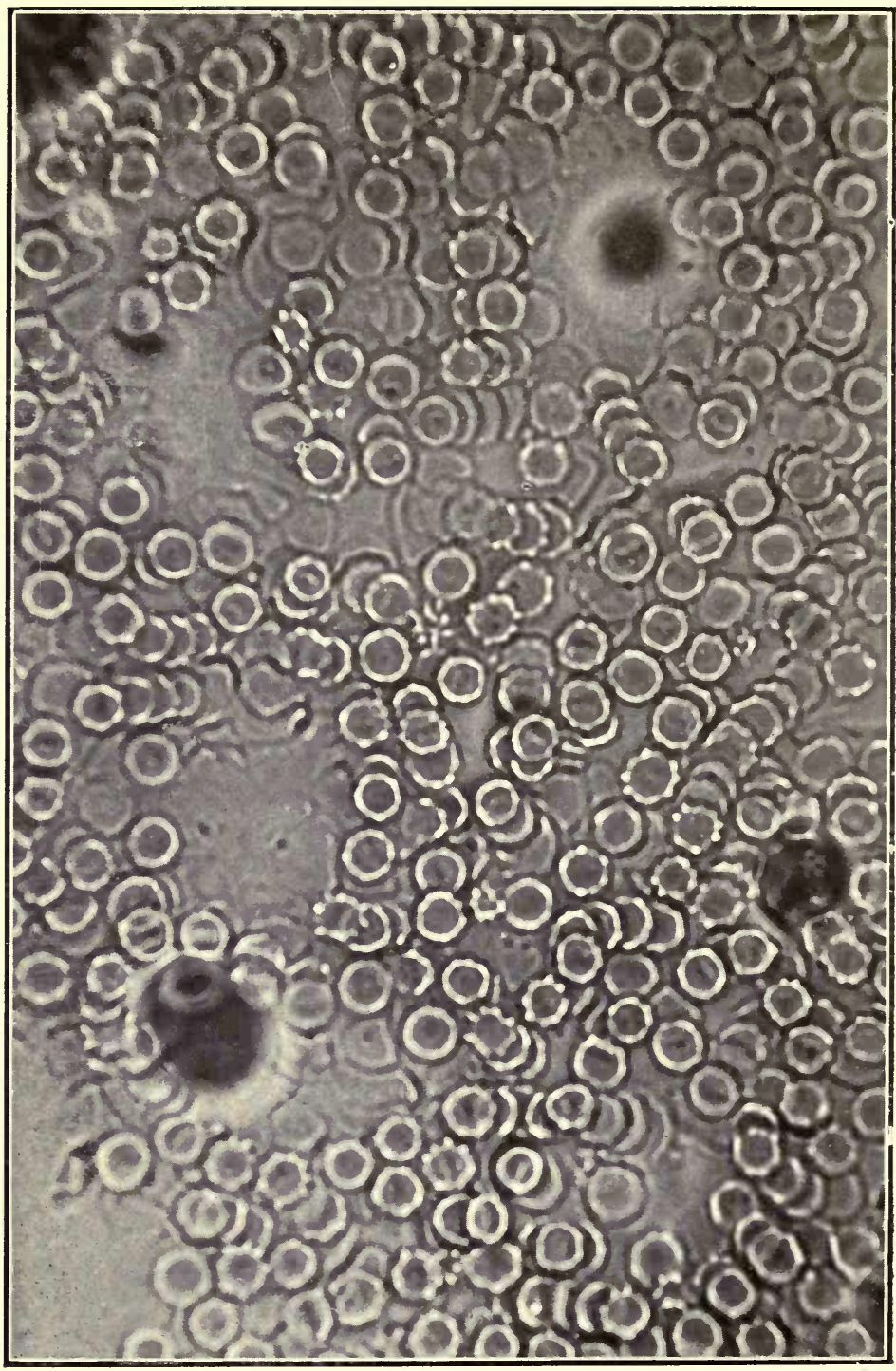

FIG. 5 I.

HUMAN BLOOD.

$\times 1000$ 
lidæ they are bi-convex and oval. There is no nucleus observable in the red corpuscles of the human being. There are also a few nucleated 'white' corpuscles which contain no hæmoglobin.

Red and white corpuscles are now generally known as 'coloured' and 'colourless.'

The proportion of coloured corpuscles in health is from between 400 and 500 to one of the colourless, but in disease there are only about ten coloured to one of the colourless.

In the moist state the coloured corpuscles of healthy blood form 45 per cent. by weight of the whole mass of the blood.

In the average healthy blood there are $5,000,000$ corpuscles per cubic millimetre. The colourless corpuscles are known as leucocytes. The coloured corpuscles of the Camelidæ have no nucleus, but in birds, fishes, and reptiles the corpuscles are oval, bi-convex, and nucleated.

No corpuscle similar to the coloured corpuscle is found in the blood of invertebrate animals, but bodies not unlike the colourless corpuscles are seen. 
Corpuscles were first seen in the blood of a frog by Swammerdam in 1658, by Malpighi in that of the hedgehog in 1661, and by Leeuwenhoek in the blood of man in 1673 .

\section{Uses of Blood.}

(1) 'To be a medium for the reception and storing of matter (food, drink, and oxygen) from the outer world, and for its conveyance to all parts of the body.

(2) 'To be a source whence the various tissues of the body may take the materials necessary for their nutrition and maintenance, and whence the secreting organs may take the constituents of their various secretions.

(3) 'To be a storehouse of potential energy, by the expenditure of which the heat of the body may be maintained; and by correlation, vital and other force may be manifested.

(4) 'To be a medium for the reception of refuse matters from all the tissues, and for their conveyance to those organs whose func- 


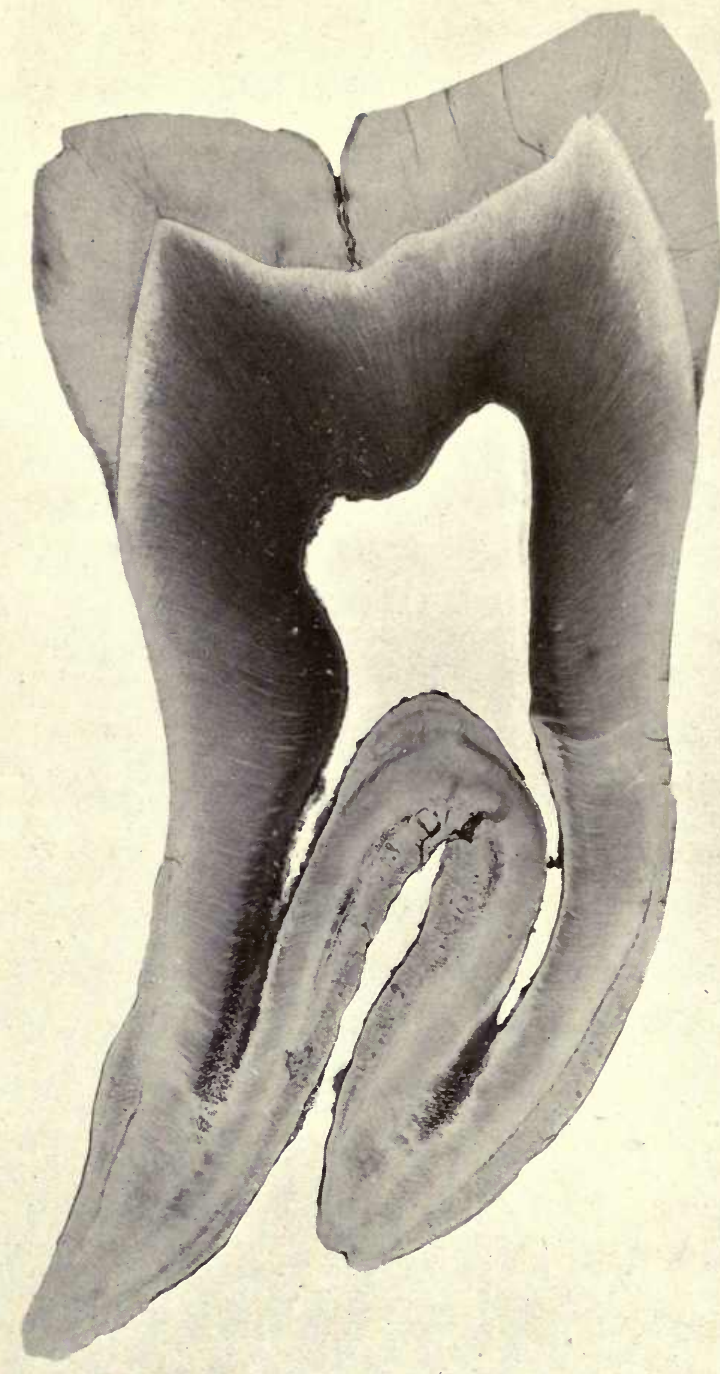

FIG. 52.

HUMAN TOO'TH, VERTICAL SECTION. $\times 8$.

[to face page 167. 


\section{STRUCTURE OF HUMAN TOOTH I67}

tion it is to separate them and cast them out of the body.

(5) 'To warm and moisten all parts of the body.' *

The illustration (Fig. 51) is taken from a photo-micrograph showing human blood corpuscles amplified to 1,000 diameters. The exposure required was 25 minutes; the focal length was 25 inches; the one-sixth objective and an eyepiece of 7 diameters were used.

\section{Section of Human Tooth.}

The vertical section of the human tooth, roughly speaking, shows the enamel on the crown, the dentine, the neck, the fangs, the pulp cavity, and the Crusta petrosa, or cement which surrounds the fangs.

The dentine constitutes the greater portion of the substance or mass of the tooth; it corresponds with the ivory in the tusks of other creatures, and is whitish and of a silky

* Kirkes, Handbook of Physiology. Morrant Baker's Edition. (John Murray.) 
lustre. It forms the entire boundary of the pulp cavity, with the exception of a small portion at the base of the fangs.

The dentine, or ivory, consists of a vast number of tubes or canaliculæ called the 'ivory tubes.' They are shown in the illustration as extremely fine tubes, pursuing an undulatory course, at first curving, then bifurcating, and continually giving out numerous fine lateral communicating branches.

The enamel covers the body of the crown. It is thickest at the opposing surface, decreasing towards the neck, where it terminates. The enamel is covered by a very thin membrane, which contains calcareous matter. This can be dissolved by the action of muriatic acid.

The enamel has a fibrous aspect, and appears of a bluish-white colour by reflected light, and of a greyish-brown by transmitted light. It is very brittle, and so hard as to strike fire with steel. It consists of numerous solid fibres, or prisms, mostly six-sided, wavy, and transversely striped. These usually ex- 
tend throughout the thickness of the enamel and are generally perpendicular to the surface of the ivory they cover. The cement or bone of the tooth does not differ structurally from ordinary bone, excepting that it rarely contains Haversian canals.

The photo-micrograph from which the illustration (Fig. 52) was taken shows an amplification of 15 diameters; the focal distance was 50 inches; and the $\frac{3}{4}$-inch objective was used.

In the next illustration (Fig. 53) we have represented a vertical section through the jaw of a kitten. This shows the positions of both the 'milk' and the 'permanent' teeth.

The photograph shows an amplification of 26 diameters; the focal distance was 84 inches; the time of exposure to gaslight was 10 minutes; and the objective used was the $3 \frac{1}{4}$-inch. 


\section{CHAPTER XVII}

\section{PARASITES OF IGUANA, BUFFALO, SHEEP, AND BEE; THE CHEESE MITE}

\section{Ixodes.}

CPEAKING generally, the enthusiastic student of the microscope rarely objects to study any insect or other creature that to the ordinary observer appears unattractive, or even objectionable. $\mathrm{He}$ is sure to find something of an attractive or interesting character in some part of its structure or history-e.g., the scales on its wings, the complex arrangement of its eyes, its breathing apparatus, its mouth appendages, \&c.

But frequently, beyond all these fascinating materials of study, he has higher aims in view. $\mathrm{He}$ is in the pursuit of knowledge. There is 


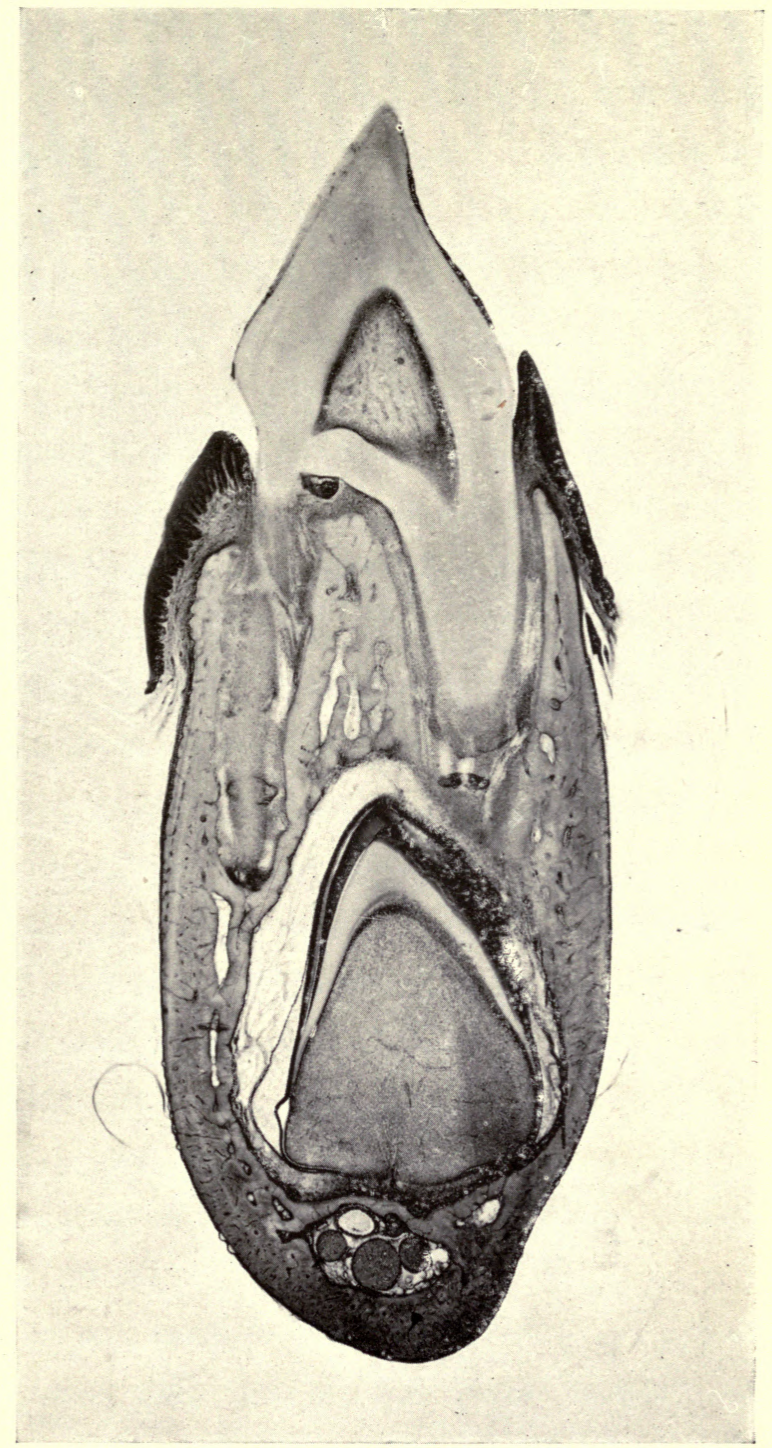

FIG. 53.

KITTEN'S JAW. VERTICAL SECTION SHEWING THE "MILK TOOTH BEING DISPLACED BY THE PERMANENT TOOTH.

X I 2 .

ser page 16g. 

some epidemic or some disease, the causes of which are only surmised. The parasites, germs, bacilli, suspected, have to undergo rigorous examination, so that their whole development may be made known, and the cause of the disease or other trouble ascertained.

Pasteur with his microscope was able to save the vintage and the silk industries of the Continent. Owing to the microscopic study of parasites, bacilli, \&c., our medical men are gradually becoming more skilled in their methods of conquering some diseases, in preventing others, and in rendering some of them less dangerous to human life.

Malarial fever, now known as being chiefly caused by the mosquito-Anopheles-as noticed in another chapter, is a case in point.

Miss Ormerod, armed with her microscope, helped the farmers by showing to them the life-history and habits of the insect-enemies of their crops.

Certain insects may be objectionable in appearance and habits, but their history, mode of development, \&c., must be known before we 
can be prepared to stop their ravages or the results directly or indirectly arising out of their existence. This age in which we live will be referred to in history as the age in which this special line of research was initiated.

At the meeting of the British Association recently held it was conclusively shown that the disastrous plague is spread throughout India by the agency of a parasite.

We have four creatures to notice, which cannot be recommended for any apparent beauty they may possess. If they have elements of beauty, it is probable these are only recognised and fully appreciated by their own species.

They differ from insects in general chiefly in that they possess eight legs instead of six; the thorax also is fused with the abdomen, while the abdomen is not divided into segments.

The mouth-appendages are adapted for piercing, sucking, or biting.

A very wonderful tracheal system is usually present. 


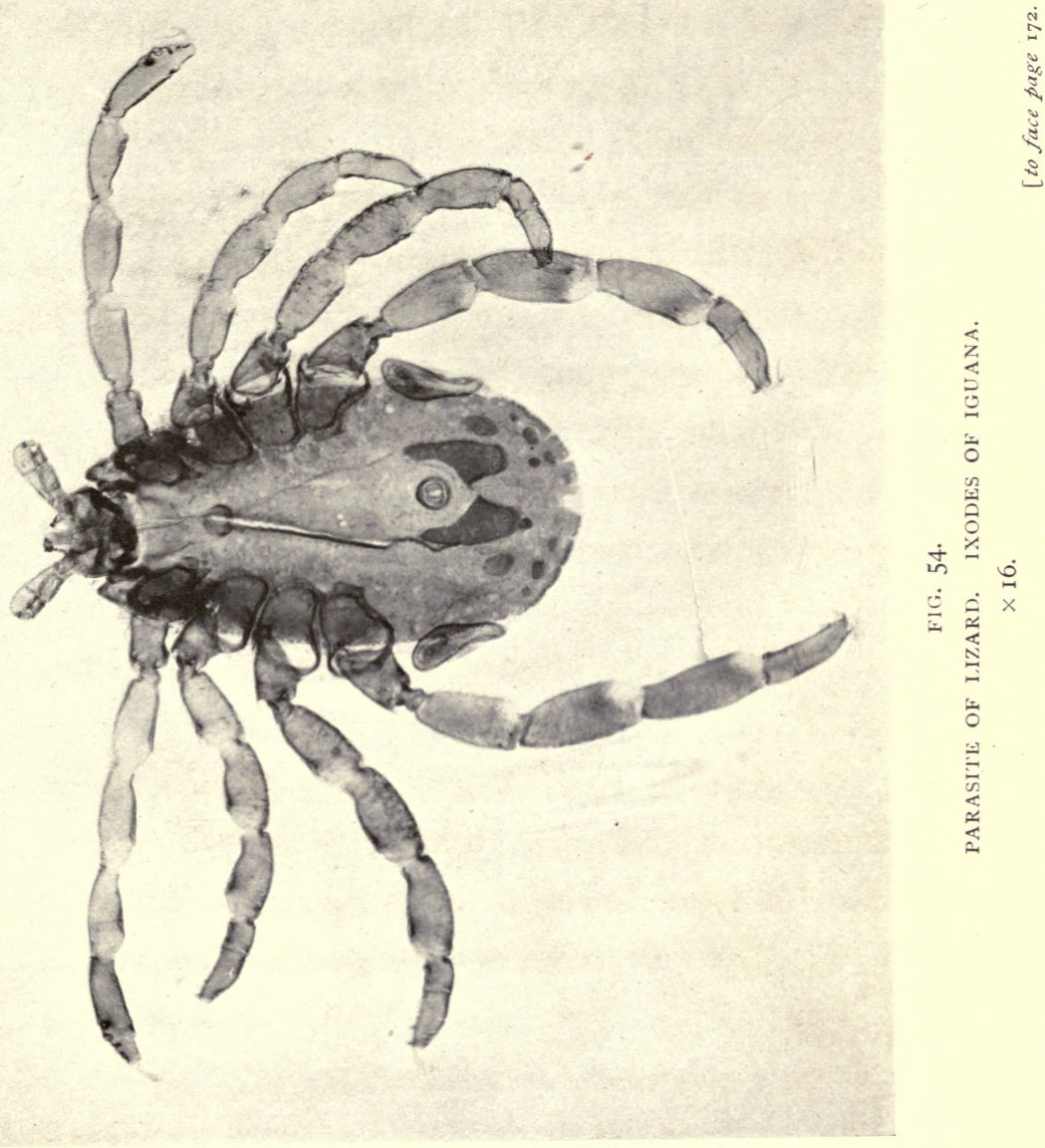





\section{STRUCTURE AND HABITS}

The four pairs of legs are segmated and usually end in claws, but these may be replaced by a sucking-disc.

The claws are wonderfully adapted for cling. ing round the hairs of animals upon which they may be living as ectoparasites.

The creatures are classed with the Acarinai and are looked upon as ticks.

It is thought that originally they were vegetable feeders. Even now they feed on vegetable matter, but are ever ready to attach themselves to animals and to perforate the skin with their saw-edged trunks. Cattle and snakes are their chief victims.

They are greedy creatures, and will suck blood to such an extent that their bodies sometimes swell to the size of a small walnut.

They have a large plate on each side of the ventral part of the body, which may act as a sucker of attachment, or it may do similar duty to that of the spiracle of the water beetle, noticed in another chapter.

This sucker-plate forms a very beautiful object for the microscope. 


\section{Ixodes of Iguana.}

The first of these is Ixodes, an external parasite on the lizard Iguana.

The illustration (Fig. 54) is from a photomicrograph of 30 diameters; the focal distance was 30 inches; and the objective used was the 1-inch.

\section{The Hæmatopinus.}

This creature is the parasite of the buffalo, and it belongs to the sub-order Parasitica.

It is devoid of wings, and dwells on the skin of the buffalo, sucking its blood.

The proboscis is fleshy and unjointed; there are two simple eyes; the antennæ have five joints; the legs arise from the edge of the pro-thorax, and they terminate in a hooked claw. This forms an admirable apparatus for clinging on to the hairs of their hosts. The young do not undergo any metamorphosis.

The illustration (Fig. 55) is from a photomicrograph of 40 diameters; the time of exposure to gaslight was two minutes; the focal 


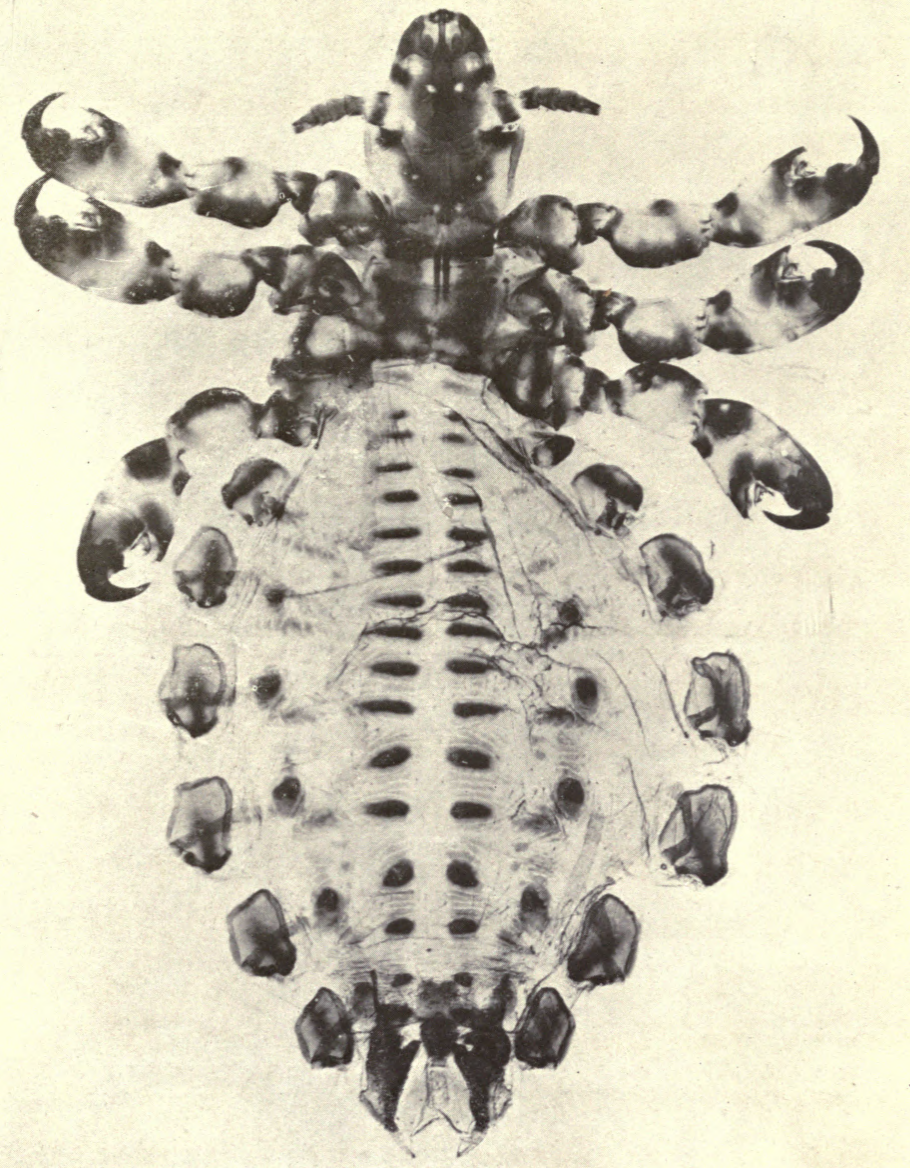

FIG. 55 .

HÆMATOPINUS OF BUFFALO.

$\times 25$. 

distance was 27 inches; and the objective used was the inch and a half.

\section{The Sheep Tick.}

The zoological name of the Sheep Tick is Melophagus ovimus. It belongs to a division of the Diptera, or two-winged insects, known as the Hippoboscida. The wings are variable, sometimes present and large, sometimes mere strips.

In the same group with the Sheep Ticks are the Forest-fly, the Horse-fly, \&c.

The proboscis is of peculiar formation, and is not like that of other flies. It consists of two elongate, closely-adapted hard flaps, capable of diverging laterally to allow of an inner tube to be passed out from the head.

The Sheep Tick seems to be specially adapted for creeping about on the skin of the sheep beneath the wool.

Its life-history is not fully known. The creature, unlike most other insects, lays but one egg at a time, which becomes hard externally. 
The larva from the egg has no true head. Its tracheal system is also peculiar.

The illustration (Fig. 56) is taken from a photo-micrograph of 32 diameters; the time of exposure was one minute; the focal distance was 64 inches; and the objective used was the 2-inch.

\section{Braula Cæca.}

Notwithstanding its name, this insect is not blind. Its eyes are not so highly organised as are those of many other insects, but it can see over short distances, and that is all it requires.

It lives as a parasite on the honey-bee, and is of necessity an exceedingly small creature. Lucas says that it specially affects the thorax of the bee. Müggenburg believes it pays special attention to the queen bee, because of the exposed membranes between the segments of the body.

Boise, another observer, says that the creature, not content with living on the bee, 



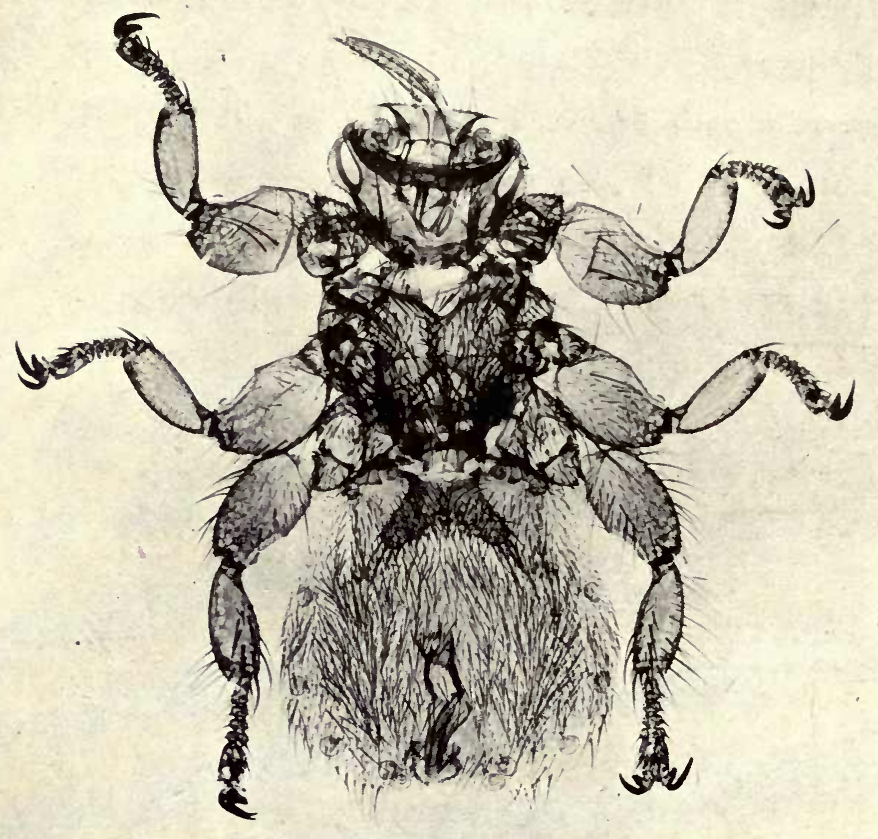

FIG. 56 .

SHEEP TICK.

$\times 14$. 
deposits a pupa in the cell beside the young larva of the bee, and that the young Braula appears as a perfect insect in 21 days.

It is Packard's opinion that on the day the larva hatches from the egg it sheds its skin and turns to an oval puparium of a dark brown colour.

By comparing the antennæ with those of the sheep tick a resemblance will be noticed, though they are not so completely concealed in their cavities.

In the original photo-micrograph this parasite is (Fig. 57) shown with an amplitude of 220 diameters; the focal length required was 66 inches; an eye-piece of 5 diameters and a 1-inch objective were used.

\section{The Cheese Mite.}

The name by which this creature is now known is Tyroglyphus siro. The creature is classed with Ixodes, and therefore belongs to the Acarina. It has a peculiarly-shaped proboscis in the form of a cone. It possesses 
four pairs of legs, which are five-jointed and have lobes for attachment and claws. Large suckers, especially in the male, are located near the posterior end of the body. The snout appears to do the duty of mandibles.

The powder of old, dry cheese consists almost entirely of mites and their eggs. The eggs are hatched in about eight days.

The illustration (Fig. 58) is taken from a photo-micrograph of 250 diameters; the focal distance was 75 inches; an eye-piece of 5 diameters and a 1-inch objective were used. 


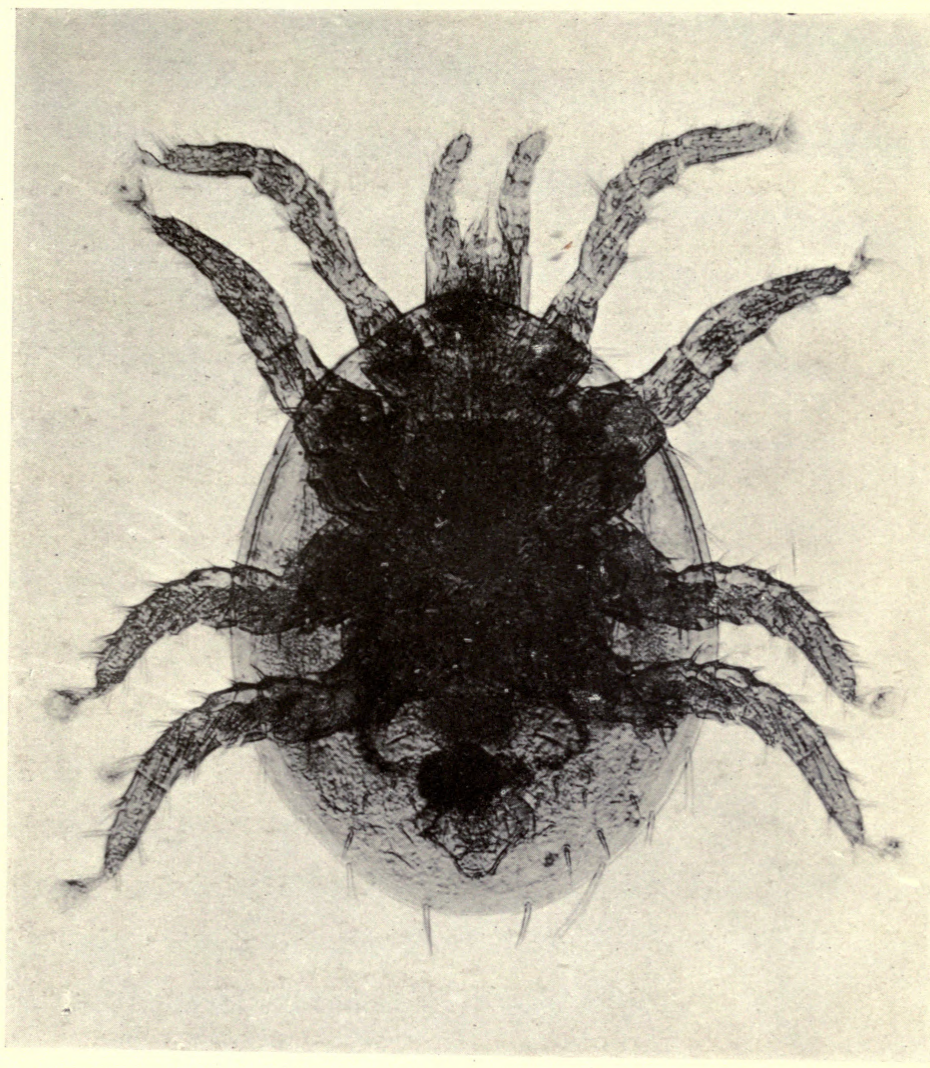

FIG. 57 .

PARASITE OF BEE.

$\times$ IOO. 



\section{CHAPTER XVIII}

A W A T E R-M I T E. (Mideopsis orbicularis.) SPIDER'S FOOT AND WOLF SPIDER

\section{A Water-Mite.}

(Mideopsis orbicularis.)

П $\mathrm{HE}$ tiny Water-mite (Fig. 59) is a new 1 discovery, and has recently been shown at the Quekett Club by Mr. Henry Tavener, the discoverer. It will be sure to interest those who study pond-life. Its body is almost a true circle. Each of the eight legs consists of five segments, the hairs of which point backwards. The object is an exceedingly beautiful one under the microscope.

The original photo-micrograph shows the creature as if amplified to 90 diameters; the focal distance was 75 inches; and the objective used was the $\frac{3}{4}$-inch. 


\section{Spider's Foot.}

The Spider's foot always excites the admiration of every one who watches it attentively as it is employed by the spider in its many operations.

It is constructed upon a very curious plan, and is evidently adapted for a variety of duties, reminding one of the American tool that can be utilised for six or seven other tools as necessity arises. But its chief functions appear to be connected with those of the spinnerets, when it renders admirable service in 'ropedrawing' and guiding.

The foot has three strong, horny claws; on the largest of these there are eighteen teeth like those of a comb, while fifteen appear on the next claw and three or four on the smallest. These are quite distinctly seen on the original photographic plate. Doubtless with this apparatus the spider can regulate the rate of issue of the filaments as they proceed from the spinnerets. The use of the word 'spinneret' is unfortunate, as the spider does not spin. 


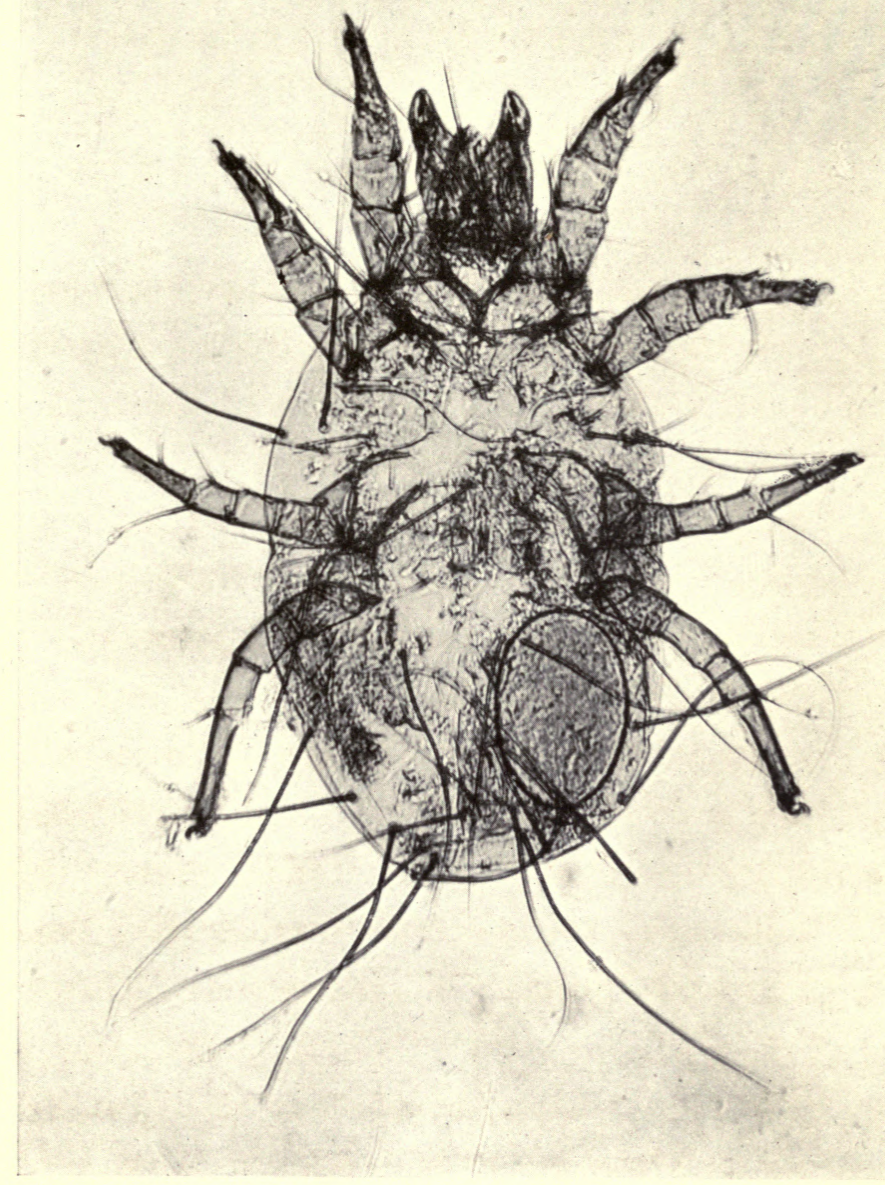

FIG. 58 .

CHEESE MITE.

$\times 125$. 




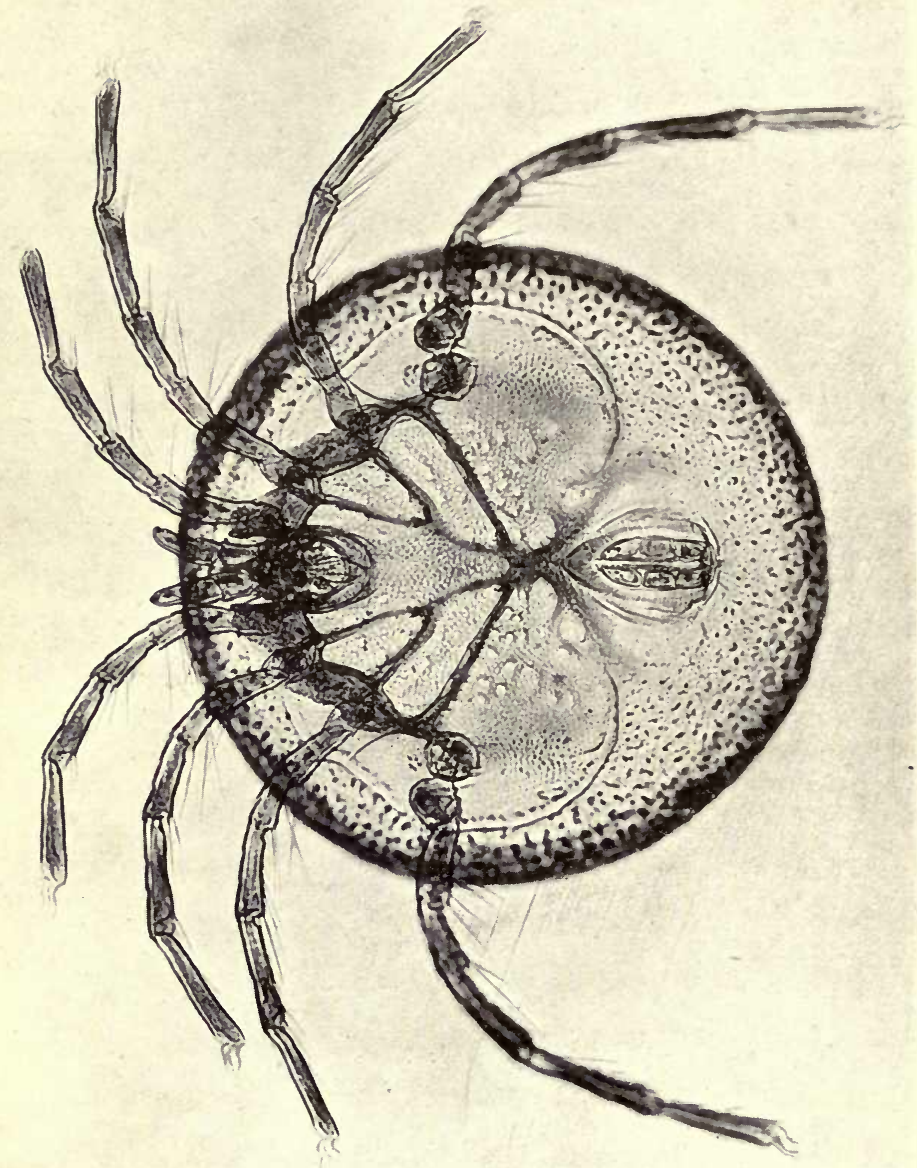

点 
By its feet it can suspend itself on its almost invisible thread. The comb-claws are frequently used for cleansing purposes, in much the same way as the house-fly uses its feet.

That the creature possesses some kind of telephonic or telegraphic power is evident to any close observer of the ways of the garden spider. Whatever the nature of the power may be, it is certain that the Spider can, when quite out of sight in a remote end of its home, locate the exact position of a fly on the web. Dr. Dallinger and other writers attribute this power to the exquisite sensitiveness of the spider's feet. 'By resting these upon a trap-line of silk carried to her den she can, by a veritable telegraphy, discover instantly, not only the fact that there is prey upon her snare, but the exact spot in the web of the snare in which that prey is entangled. In the same way by seizing certain tautened threads communicating with the main lines of the snare, she can discover in an instant the presence and position of her prey, though far beyond the reach of vision.' A veritable and wonderful system of telegraphy 
indeed, and all contained within very limited dimensions! This is another instance of modern science anticipated by one of Nature's tiny creatures.

Spiders not only have done this, but they also aid science very materially owing to the extreme fineness of their silken threads. The astronomer encourages the spider for the sake of its web, the strands of which are finer than any other substance he has access to, and are used for micrometer lines in the eye-pieces of his telescopes.

The Garden Spider displays great ingenuity in the protection of its web on windy days. The writer's attention was drawn one stormy day to a large web at the end of the garden. It was stretched from a cabbage to the paling; it was a frail-looking structure, and apparently was not strong enough to last long in such weather. Still, it withstood the storm, and this is where the spider's instinct rose to the occasion. A long thread of silk depended from the centre of the web and hung down a considerable distance below. To the end of this thread was 



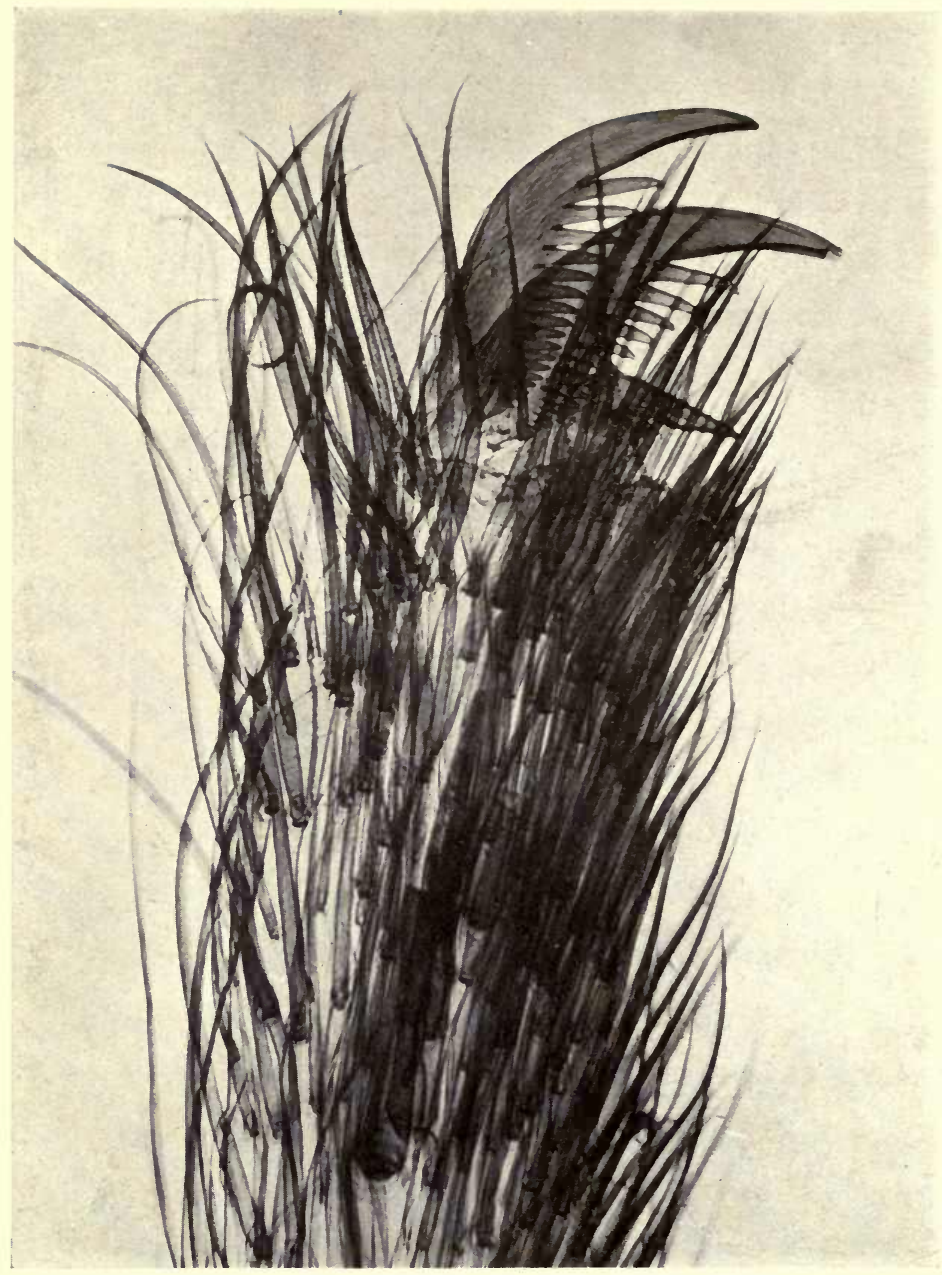

Fig. 60 .

SPIDER'S FOOT AND PART OF I.EG.

$\times 125$.

[to face page 183. 
attached a ball of clay about the size of a small marble. The clay ball was literally wrapped up in web material. Its use was obvious. When the web was blown one way the plumb pulled in the opposite direction, and so the snare was kept comparatively steady. It was a success-it withstood the storm !

Blackwall, the great authority of the past generation on spiders, states that two different kinds of materials are used in the construction of their nets. The boundary lines, the radii and the first-formed spirals are unadhesive, and possess only a moderate share of elasticity; they are evidently composed of a different material from that used in making the spiral line which completes the web, which is exceedingly viscid and elastic in a remarkable degree. The viscidity of the spiral thread may be shown to depend entirely upon the presence of a series of globules, resembling tiny beads; if these be removed, a fine glossy line is left which is highly elastic but perfectly unadhesive.

Dr. Dallinger tells us that these beads, or globules, are produced after the thread is drawn 
out, by a special vibratory action set up in the thread by the spider!

The original photo-micrograph (Fig. 60) shows this foot amplified to 260 diameters. The approximate focal length was 37 inches; an eye-piece of 7 diameters, and a 1-inch objective were used.

At the request of the editor of Knowledge this appeared in a whole-plate illustration in the July number of that magazine, 1904.

\section{The Wolf Spider.}

(Lycosa.)

The Wolf Spiders usually pursue their prey by running after them, hence their name. There are some spiders that do not seem to be able to run, but are good jumpers. Of these Salticus tardigradus and Pelenes tripunctatus are English examples. The former are usually found in park overlapping palings, the latter at the base of the undercliffs near the seashore. The Wolf Spiders are numerous, and are found near most woods in England. 


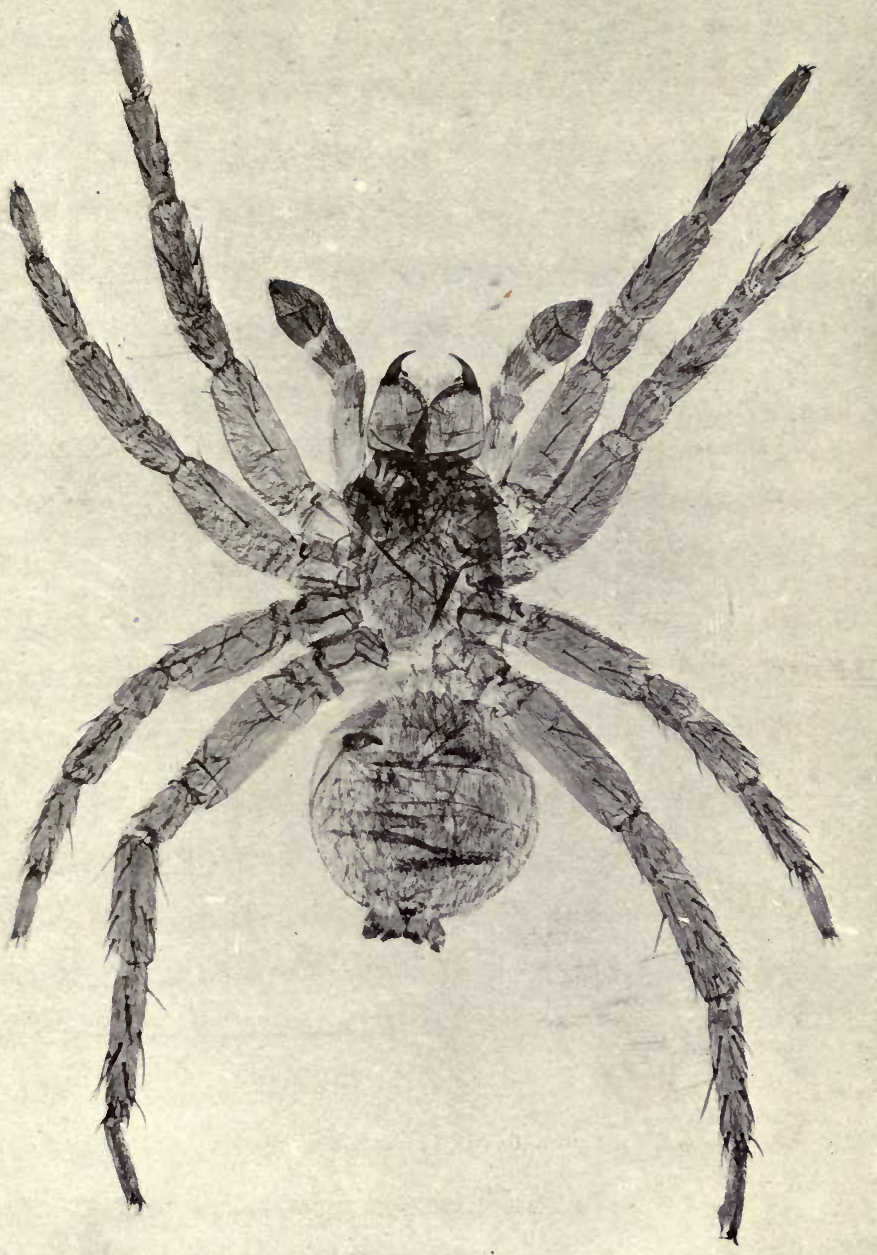

FIG. 6I.

WOLF SPIIER.

$\times 9$. 
They have eight eyes arranged in transverse rows. Their legs are long and hairy. The female carries the egg-pouch about with her, attached to the end of her body till the young are hatched, when they climb on her back. To this family belongs the famous spider Lycosa tarentula (Linn.). Its bite was supposed in Italy to bring on a fit of melancholia that could only be cured by the tune known as the Tarentella.

The nests of some of these spiders are hardly less curious than are those of the Trap-door Spiders. Of these a North American species, Lycosa arenicola (Scudder), makes a structure resembling a huge bird's-nest or small turret over the entrance to the tube. Some of the Lycosidæ frequent water and are able to pursue their prey on it or in it. The Dolomodes fimbriatus (Clerck) actually constructs a small raft, on which it sails about.

Connected with the life-history of the Lycosa is an interesting insect, the Mantispa. In the spring, when these spiders have formed their bags of eggs, the minute larvæ of the Mantispa 
find them out, tear a hole in the bag, and enter among the eggs; here they wait until the eggs have attained a fitting stage of development before they commence to feed. Brauer found that they ate the spiders when these were quite young, then they changed their skin for the second time and also underwent a great change of form.

The newly-habilitated Mantispa spins a cocoon in the interior of the egg-bag of the spider, and changes to a nymph inside the larva-skin. Finally the nymph breaks through the barriers, larva-skin, cocoon, and egg-bag of spider, by which it is enclosed, and appears shortly afterwards as a perfect Mantispa. The mother spider, although watching over the development of her eggs, seems to be unconscious of the havoc that is going on among her young.

The illustration (Fig. 61) is taken from a photo-micrograph showing the creature as if amplified up to 18 diameters; the focal distance was 36 inches; and the objective used was the 2-inch. 



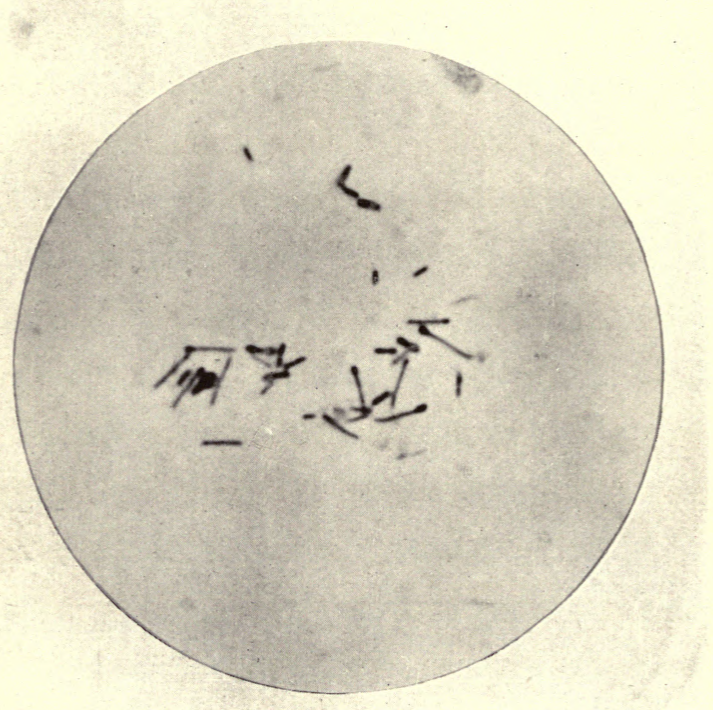

FIG. 62.

TETANUS (LOCKJAW) BACILLI. $\times \mathrm{I}, \mathrm{COO}$. 


\section{CHAPTER XIX}

\section{TETANUS (LOCKJAW) BACILLI ; SCALES OF THE SOLE}

THATEVER else there may be of importance or otherwise in these chapters, there can be no doubt as to the interest of the discovery made quite recently by a medical friend. The extremely useful purposes to which photo-micrography can be applied have rarely met with a better illustration.

The doctor was called to see a child seriously ill, and he diagnosed the trouble as tetanus in its most virulent form. As a result of a strict investigation as to its cause the fuller's earth used by the nurse came under suspicion, especially as tetanus bacilli 
are found in most samples of cultivated soil. He took it away. He had cultivations made by inoculating a nutrient glucose broth (peptonised juices of meat with sugar) with a portion of the fuller's earth, thus enabling any bacilli present to germinate. The tube containing the inoculation was then kept in water at a temperature of $80^{\circ} \mathrm{C}$. for ten minutes, when all non-sporulating organisms were killed off. This was then incubated for forty-eight hours in another tube (Buchner's), with a bulb at the lower end filled with equal quantities of strong pyrogallic acid and a 20 per cent. solution of $\mathrm{KOH}$ (caustic potash), so that all free oxygen was absorbed; oxygen being inhibitory to the growth of the tetanus bacilli.

A specimen from the culture so obtained was mounted in the ordinary way and stained with fuchsin. Under the $\frac{1}{12}$ th oil immersion lens bacilli were discovered. The bacilli of tetanus are immobile, and from their shape they are termed 'drumstick.' The illustration (Fig. 62) shows several specimens of this shape. 
This discovery concerns alike doctors, nurses, and parents. The mortality among infants is enormous, and is commented upon almost daily in our papers. Here, apparently, is one cause of at least one of the fatal diseases. Fuller's earth must be abandoned altogether as a dressing for open wounds, however produced, or its sale in an unsterilised form be prohibited.

The illustration is from a photo-micrograph, showing the 'drumstick' bacilli amplified to 1,000 diameters. As already stated, the objective used was a $\frac{1}{12}$ th oil immersion.

\section{Scales of the Sole.}

The imbricated arrangement of the scales covering the skin of the sole makes this fish of more than ordinary interest to students with a microscope. The illustration (Fig. 63) is from a negative of 36 diameters. 


\section{CHAPTER XX}

\section{CIRCLET OF SCOLEX ; SILK}

\section{The Circlet of Scolex.}

THIS beautiful object is scarcely visible to

1 unaided eyesight, both because of its minuteness and of its transparency. In the original photo-micrograph it looks like a piece of sculptured marble. Three questions naturally arise in connection with this curious object. First, is the circlet arranged artificially? What are its uses? And what is a scolex?

The circlet occupies this form in Nature, and is arranged around the head of a tiny creature. Its mission is to hook on to certain internal parts of creatures on which 


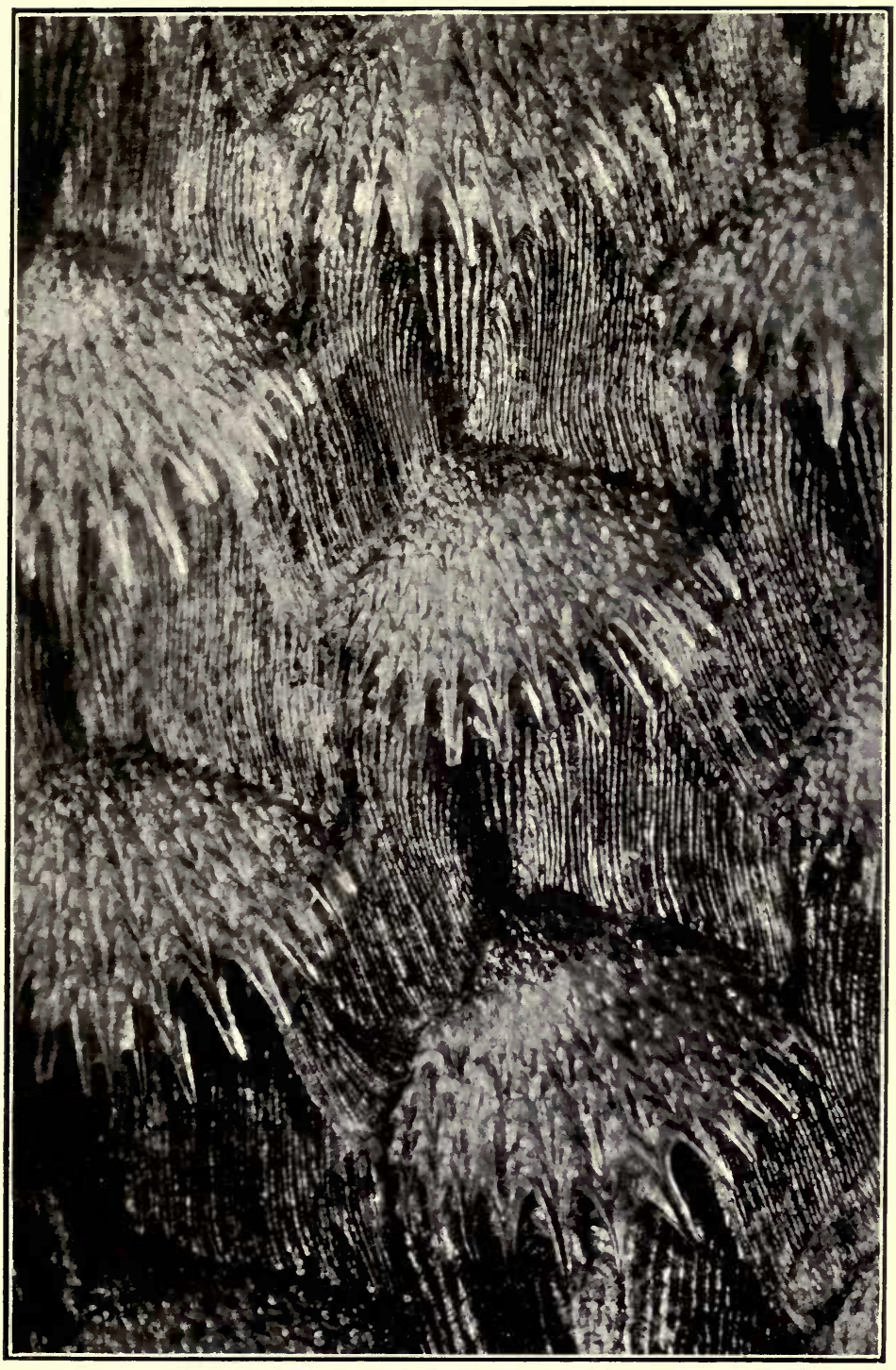

FIG. 63. 

it subsists, and in which it undergoes development into a more advanced stage of life.

Finally, what is a Scolex? Only medical students will be interested in the answer.

Professor Siebold long suspected that the ring of horny spines forming the armature of the Cysticercus fasciolaris met with in the liver of the mouse, and a similar structure in Tania crassicollis, found in the cat, strongly resembled each other, and at length, by experiments which we need not describe, ascertained beyond the possibility of a doubt that they are identically the same.

Küchenmeister also found by experiments with animals that Canurus cerebralis and Cysticercus cellulosa are but Scoleces in the ordinary chain of life of the tape-worm.

Van Beneden's researches led to the same result.

We may feel somewhat squeamish about the mention of Entozoa, but it is better to know something of the life-history of these internal enemies of the human being, and benefit by the knowledge, than to remain in 
ignorance and eat certain foods, or food insufficiently cooked, thereby incurring distressing consequences.

The scolex, then, is but one stage in the life of a Tænia. The Cysticercus is another, equivalent to the larval condition. In this form it occurs in the cellular tissue of the pig, and produces the disorder known as 'measly pork.' It is also found in the ape, dog, ox, rat, \&c.

When in large numbers, as in the Cænurus stage, it appears in the brain of the sheep, and causes the disorder known as 'staggers.'

A long account of this uninviting subject is to be found in Rymer Jones's Animal Kingdom.

The original photo-micrograph (Fig. 64) shows an amplification of 550 diameters; the focal distance was 50 inches; an eye-piece of 5 diameters, and a $\frac{1}{2}$-inch objective were used.

\section{Silk.}

It is not necessary to say much about silk. Every one knows how it is produced, 



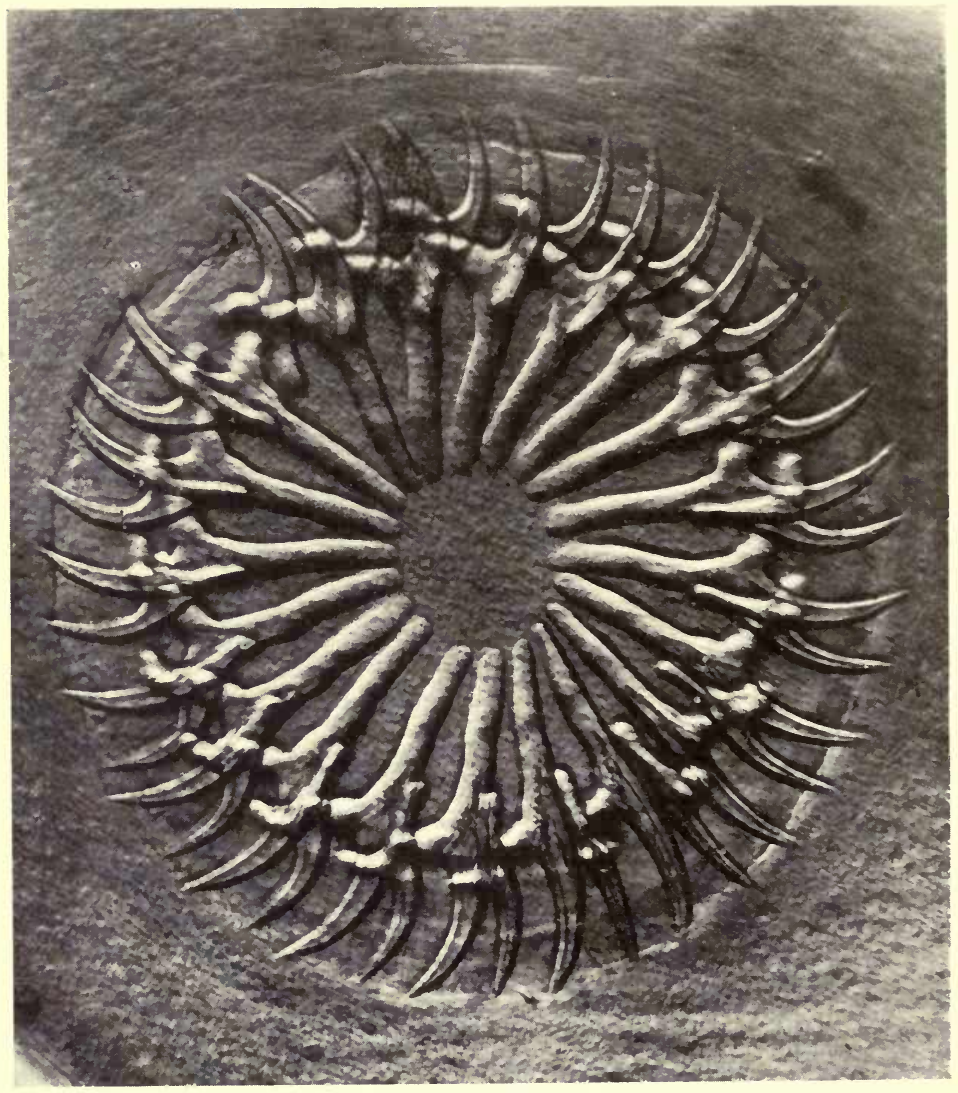

FIG. 64 .

CIRCLET OF HOOKS ON A SCOLEX.

$\times I 50$.

[To face page Ig. 
and the life-history of the moth is also well known. But a portion of manufactured silk is here shown to illustrate the coarse workmanship which the workman considers fine. The amplification is only a fraction of that which some of the objects described in other chapters have undergone. If it had been magnified on the same scale as any of the diatoms, it would have appeared as coarse as a door-mat. Search where we may among the finest art treasures, the costliest miniatures on ivory, the finest linen, or anything else that displays man's highest skill and most artistic taste, and all will appear rough and uneven under the microscope. This portion of silk (Fig. 65) was, in the first instance, photographed through the microscope and amplified to 50 diameters; the focal distance was 50 inches; and the objective used was the 1-inch. The object being opaque reflected light was required; hence the exposure (15 minutes) was long.

The piece of silk selected was not coarse as compared with other silks. This contrast 


\section{I94 IMPERFECTION OF MAN'S WORK}

between man's most tasteful work and that of the humble things of Nature ought to impress us more than it does. It is humiliating, in a sense, that if we amplify man's work its deficiencies and imperfections increase with the amplifying process, but the opposite occurs with Nature's works. The more we enlarge the microscopic natural history object the more wonderful it appears.

The microscope and the camera used either singly or as a combined instrument aid us in forming some faint conception of the beauty of this material world-fallen as it is-and yet so fair and so full of the Creator's wisdom.

THE END. 


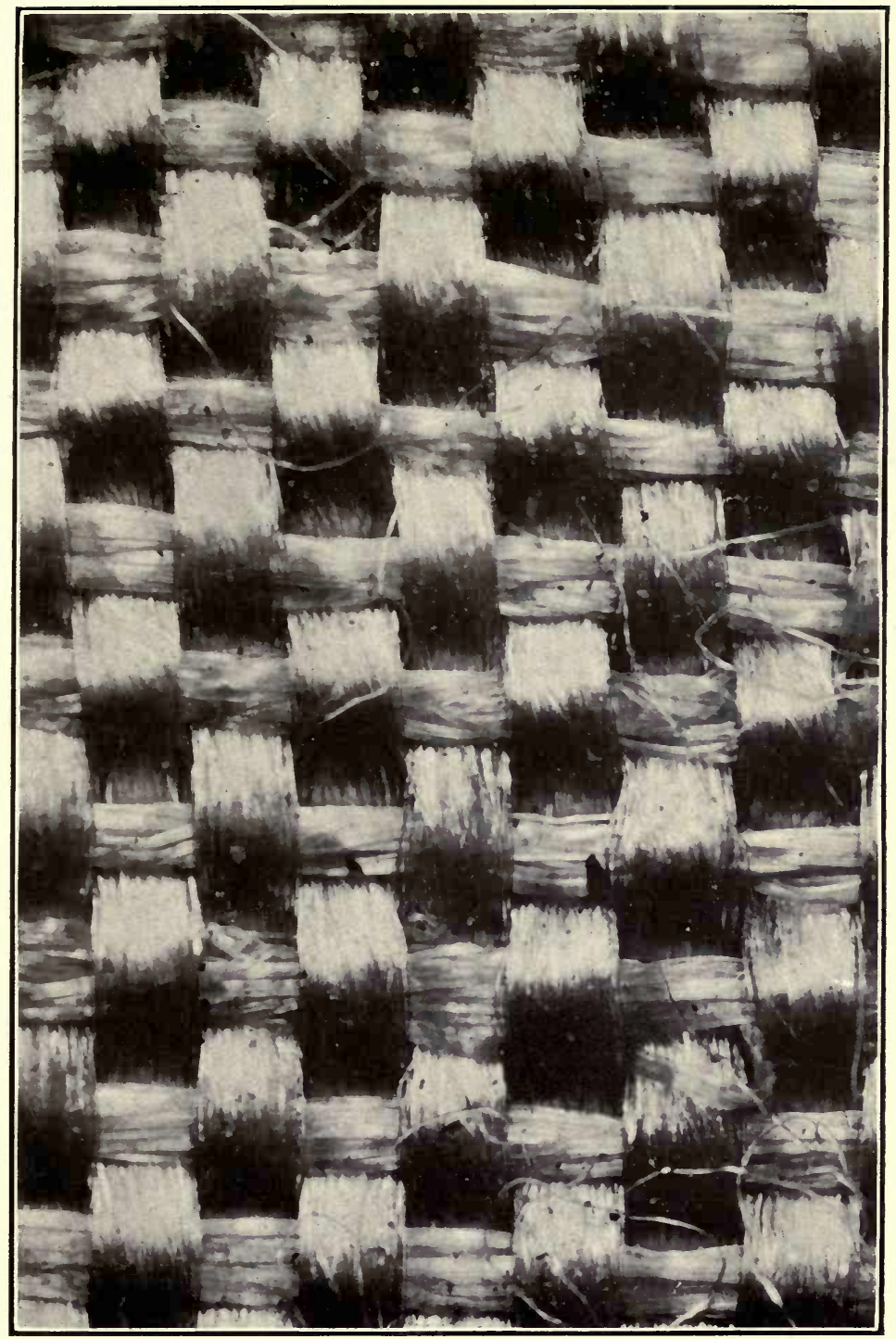

FIG. 65 .

FINE SILK.

$\times 50$.

[to face page 194. 



\section{N D E X}

Abies, 4, 138, 140

Actinocyclus Ralfsii, 110

\#gilops, 113

Anopheles, 91, 171

Ant-Lion, 93

Antenna of Melolontha, 100

Anthomyiidæ, 77

Apis mellifica, 85, 87

Aristolochia gigas, 126

Barnacle, Cirri of, 63

Bee, Leg of Honey, 87

" Tongue of Honey, 85

Bergmehl, 106

Blackwall, 183

Bone, Human, 160

Braula cæca, 176

Burmeister, 101

Butchers' Broom, 142

Butterfly's Tongue, 79

Calamus rotang, 129

Canaliculæ, 161, 168

Carpathians, 53

Cirri of Barnacle, 63

Clematis vitalba, 134

Claus, 84

Cockchafer, 100

Cole, Martin J., 49

Corpuscles, Red, 164

Coscinodiscus bi-angulatus, 111

Crane Fly, 98

Culex pipiens, 92

Cutis vera, 152

Cysticercus, 192

DadDY-LONG-LEGS, 98

Developer, 40

Diatoms, 103

Dodder on Clover, 117

Dog's Bay, Ireland, 54

Dolomedes fimbriatus, 185

Dragon-Fly, 70

Dufour, 96

Dytiscus marginalis, 82 
Echini, Spines of, 65

Egyptian Pyramids, 53

FABRE, M., 113

Foot-pounds, 159

Foraminifera, 50

Fuller's Earth, 187

Hematopinus, 174

Hair, Human, 147

Haliotis, Radula of, 60

Haversian Canals, 161

Heliopelta, 110

Henle's Layer, 147

Hicks, Dr., 101

Hippuris vulgaris, 144

Hogg, Dr. Jabez, 86

Hooker, Dr., 130

House Fly (Musca domestica), 75,78

Isochromatic Plates, 41 Ixodes, 170

Jones, Prof. Rymer, 71, 82

Kingshey, Charles, 17

LACUNA, 161

La Place, 32

Law of Restriction, 70, 71

Leeuwenhoek, 166

Lily, Bud of, 133

Limpet, Radula of, 61
Lockjaw, 187

Lung, Human, 162

Lycosa, 184

Mantispa, 185

Mare's-Tail, 144

Melolontha, Antenna of, 100

Mideopsis orbicularis, 179

Miliolida, 53

Mite, Cheese, 177

Moore, T., 113

Mosquito, 90

Muscidæ, 75

Muscle of Heart, 157

Myrmeleon, 93

NAVICULA LYRA, 110

Nelson, E. M., 35, 109

Nettle Sting, 123

Nicobar Islands, 47

Nummulitic Limestone, 53

Nuphar lutea, 136

Nymphcea alba, 136

ODONTOPHORE, 58, 61

Old-man's-beard, 135

Ormerod, Miss, 171

Patelia vulgata, 61

Pedicellariæ, 67

Pelenes tripunctatus, 184

Petiole of Nuphar lutea, 136

Plancus, 54

Pleurosigma angulatum, 34 
Polycystina, 44

Proboscis of Blow Fly, 72

Proboscis of Butterfly, 79

Radula of Limpet, 59, 60 , of Whelk, 60

Rete mucosum, 153

Rhyngia, 97

Ruscus aculeatus, 142

" androgynus, 142

", hydrophyllum, 143

Scolex, Circlet of Hooks ON A, 191

Silk, 192

Skin, Human, vert. sect., 152

Spider's Foot, 180

Smith, Worthington G., 122

Sole, Scales of the, 189

Spruce Fir, 139

Stag Beetle, 71
Stratum corneum, 153

" granulosum, 153

" lucidum, 153

Swammerdam, 166

Tetanus Bacilli, 187

Tick, Sheep, 175

Tipula, 98

Tooth, Human, 167

Triceratium favus, 111

Triticum, 112

URTICA DIOICA, 124

Victoria Land, 105

" regia, 137

Virgin's Bower, 134

Water LiLt, 136

Wheat Stem, 112

Whelk, Radula of, 60

Wolf-Spider, 184

Wolle, Rev. F., 107 
6 


\section{POPULAR WORKS \\ OF \\ SCIENCE, NATURAL HISTORY, \\ AND EDUCATION.}

Hidden Beauties of Nature.

By RICHARD KERR, F.G.S., F.R.A.S.

Author of 'Nature-Curious and Beautiful,' etc.

With 59 Illustrations from Sketches and Photographs.

Crown 8vo. Cloth. 25.6d.

'An exceedingly interesting work on an interesting subject. Mr. Kerr has laid all lovers of the microscope and of natural history under a heavy debt by his diligent enterprise and enthusiasm. His book is full of wonderful " things of beauty," and is a credit to himself and his publishers.' - Science Siftings.

Very well and abundantly illustrated, beautifully printed, and crisply written. This is a very good volume to place in the hands of a boy with a turn for science. Spectator.

'An attractive book for the young, presuming an interest in natural studies to begin with.'-Educational Times.

'I thank you for the very interesting work you have been so good as to send me.' -W. E. GLadstone.

\section{The Microscope:}

\section{A Popular Handbook.} By LEWIS WRIGHT,

Author of 'Optical Projection,' etc.

With Illustrations. Crown 8vo. Cloth. 2s. 6d.

'Mr. Wright's practical suggestions will be of great value, not alone to beginners.' -Times (Weekly).

'Deals in a plain, attractive manner with the practical optics of the microscope. Pall Mall Gasette.

'Should form a capital guide and tutor for the inexperienced.'-Science Siftings.

\section{Through a Pocket Lens.}

By HENRY SCHERREN, F.Z.S.,

Author of 'Ponds and Rock Pools,' etc.

Profusely Illustrated. Crown 8vo. Cloth gilt. 25 .

'The object of this book is to show what an immense deal lies just beyond the perception of the naked eye, waiting to be revealed by the application of the simplest and cheapest forms of magnifier. The author explains what a mistake it is to suppose, as so many beginners in scientific observation do, that a costly compound microscope, with a host of accessories, is necessary to pry into any except the most recondite mysteries of nature; and he reminds the young student how much of Darwin's most fruitful labour was transacted by the aid of simple lenses. A book which can be confidently recommended.'-Pall Mall Gazette.

- We cannot imagine a more useful preliminary training for a young student than working with a pocket lens through the course indicated by the author?-Field.

'With this little book and an inexpensive pocket lens, the young student, whether boy or girl, will find abundant food for mind and recreation for many a year to come. - Science Gossip.

\section{LONDON : THE RELIGIOUS TRACT SOCIETY.}




\title{
Insect Lives as Told by Themselves.
}

\author{
By EDWARD SIMPSON.
}

With many Illustrations. Crown 8vo. Cloth. Is. 6d.

' This pretty little book contains nineteen autobiographies of insects, including representatives of all the thirteen chief orders of the class. An excellent first book for young readers. The types chosen are thoroughly representatlve.'-Nature Notes.

'Our boys and girls ought to learn Natural History when it can be acquired in such a fascinating fashion as this, and they cannot read the book without being again and again reminded of the great Creator's care for even the least of the creatures He has formed.'-Sword and Trowel.

\section{The Daisies of Nazareth. Words to Young People from the Bible and Nature.}

\author{
By HUGH MACMILLAN, D.D., LL.D., F.R.S.E., \\ Author of "Bible Teachings in Nature," etc. \\ With Frontispiece. Crown 8vo. Cloth gilt. 2s. 6d.
}

Dr. Hugh Macmillan is well known as among the closest and most sympathetic students of Nature in our day; and by the aid of a lucid and charming style, his various writings most attractively set forth the harmony between the Word and the Works of God.

'We have seldom met with a more beautiful book of its kind, or one which treats the highest themes with more of the spirit of sweet reasonableness. Science in the present instance becomes, in truth, the handmaid of religion, and there is nothing conventional in the volume.' - Speaker.

'Full of charming illustrations from the world of nature.'-Methodist Recorder.

\section{Easy Lessons on Things Around us.}

By AGNES GIBERNE,

Author of 'Stories of the Abbey Precincts,' etc.

Illustrated. Crown 8vo. Cloth gilt. Is. $6 \mathrm{~d}$.

'Weaves a story out of the common things of life, in which information is presented as attractively as fiction.' $-R o c k$.

'A very interesting introduction to physics, written for little people. The manner in which some primary facts are stated and illustrated, together with the simple and lucid language employed, is likely to awaken an interest in science whicb many a more pretentious book would fail to secure.'-Presbyterian.

\section{Our Feathery Folk.}

\section{By MARGARET SCOTT HAYCRAFT.}

Illustrated. Crown 8vo. Cloth gilt. Is.

'It is sure to carry pleasure and instruction to many young readers.' - Sunday School Chronicle.

'Twelve charming chapters on birds and their buildings, brightness, beauty, and Bible references to them. The book is an admirable advocacy of what Carlyle called "the strength of cheerfulness," and gives some poetry musical with "the singing of birds." -Educational Nerws. 


\title{
Popular Natural History of the Lower Animals.
}

\section{Invertebrates.}

\author{
By HENRY SCHERREN, F.Z.S., \\ Author of 'Through a Pocket Lens,' etc
}

With 169 Illustrations. Crown 8vo. Cloth. 2s. 6 d.

'It gives in simple language many details concerning the structure and habits of "backboneless animals." The text is profusely illustrated, and altogether the publication is a practical elementary treatise on the invertebrates. -The Morning Post.

"It is carefully written, and quite intelligible to the ignorant. An excellent handbook.'-The British Weekly.

'Interspersed with a large number of scientific facts will be found a quantity of amusing reading.'-The Field.

\section{Creatures of the Sea. \\ Being the Life Stories of Some Sea Birds, Beasts, and Fishes. \\ By FRANK T. BULLEN, F.R.G.S., Author of "The Cruise of the "Cachalot," etc. \\ With Forty Illustrations by Theo. Carreras. \\ Demy 8vo. Cloth gilt, gilt top, 3s. 6d.}

Mr. Bullen takes his readers long and pleasant voyages over the vast expanse of the Ocean, and enables them to see with something of his own keenness of observation and sympathetic interest the wonderful varieties of animate life that are found upon and beneath its mighty waters. Those familiar with Mr. Bullen's style hardly need to be told that there is nothing of the dry scientific character about these studies. His vivid and glowing pictures of the wonderful and varied life of the Deep Sea possess a human and lifelike quality often absent from the elaborate descriptions of severer scientific and technical treatises.

\section{The Trees and Plants of the Bible.}

By W. H. GROSER, B.Sc.

Illustrated. Cloth. 2s.

'Apart from its religious value, this little volume must approve itself to all lovers of botany.:-The Times.

\section{The Animals of the Bible.}

By H. CHICHESTER HART,

Naturalist to Sir G. Nares' Arctic Expedition and Professor Hull's

Palestine Expedition.

Illustrated. Cloth. 2 s.

' One feels in reading the book that much of the information has been obtained at first hand. - The Schoolmaster.

'A capital handbook for teachers.'-The Saturday Review.

\section{Plants of the Bible.}

By Rev. GEORGE HENSLOW, M.A., F.L.S., etc.

Illustrated from Photographs of the Plants themselves.

Foolscap 8vo. Cloth. Is.

'A brief but reasonable introduction to Scriptural botany.'-The Manchester Guardian. 


\section{Rambles with Nature Students.}

By Mrs. BRIGHTWEN,

Author of 'Wild Nature Won by Kindness,' etc.

With 130 Illustrations.

Large crown 8vo. Cloth gilt, $2 s .6 d$.

'An admirable little guide for all who are weary of bricks and mortar.'Academy.

'A book which may help both teacher and pupil to see, and thus open up a new world for observation, experiment, and research. - Echo.

' So clear and bright is the style that it is not surprising that the discussion of common flints or the footmarks of animals in the snow is invested with considerable charm.'-Quees.

'Though originally intended to lead young people to cultivate habits of observation, their elders will find Mrs. Brightwen a delightíl companion for a ramble at any time.'-Evangelical Magazine.

\section{Woodland, Field, and Shore. Wild Nature depicted with Pen and Camera.}

By OLIVER G. PIKE,

Author of 'In Bird-Land with Field-Glass and Camera.'

With two Coloured Plates, and Ior Engravings of Birds, Animals, and Insects from Photographs taken direct from Nature by the Author.

Crown 8vo. Cloth gilt. 3s. 6d.

' Whether Mr. Pike writes about the denizens of a suburban orchard or a Surrey common, his matter is always interesting. All his illustrations are excellent.'Westminster Gazette.

"A very pretty book. The author has seen many curious things revealed only to the patient and careful observer of Nature; evidently also he knows how to describe what he sees. - Speclator.

Every lover of Nature should possess it, for it is pleasant reading and eminently instructive: - Amateur Photographer.

\section{How to Study Wild Flowers.}

By Rev. GEORGE HENSLOW, M.A., F.L.S., etc.

\section{Author of 'Plants of the Bible.'}

With Illustrations. Second Edition. Cloth gilt. 2s. $6 \mathrm{~d}$.

A mine of delight for the contemplative man of leisure, or the ardent student of the beauties and mysteries of God's handiwork, as displayed in the gems which adorn our fields and woodlands. '-Christian.

'If every village teacher would make this little book his boon companion, he would probably find forgetfulness of codes, inspectors, hard work, and little pay in the wonderful fairyland that lies all about him. The work is scholarly, full, and yet popular in style, $-S$ Shoolmaster.

'It is a scientific book, full of terrible names, and all so accurate and orderly, But it is also a beginner's book, and the terrible names have their teeth taken out by the homely English that follows them. It is a student's book, and some severity of study is demanded. But even that is brightened and greatly lessened by the woodcuts on every other page.'-Expository Times.

- Professor Henslow has produced a volume. which can be made of the greatest educational value, and is admirably suited alike for the private student and as a class-book.' -School Guardian. 


\section{The Brook and its Banks.}

By the late Rev. J. G. WOOD.

With many Illustrations. Small 4to. Cloth, gilt edges. 35. 6d.

- The style is very attractive, and so is the manner in which the author takes the reader into his confidence, giving him advice about observing animals, procuring and preserving specimens, and the management of an aquarium. The illustrations are numerous and good, and in harmony with the letterpress. A nicer book for boys than this it would be hard to imagine. - Spectator.

'No more delightful book can be cited among the writings of its lamented author than "The Brook and its Banks." -Saturday Review.

- Few writers have done so much to familiarise boys and girls with the simple facts of natural history as Mr. Wood, for he always painted the inhabitants of fields, forests, and rivers from actual eye-witness, and pressed home his lessons by cheery anecdotes sure to be remembered. - The Graphic.

\section{Nature, Curious and Beautiful.}

By RICHARD KERR, F.G.S., F.R.A.S.,

Author of 'Hidden Beauties of Nature,' etc.

With Sixty-nine Illustrations, from drawings made by the Author.

Crown 8vo. Cloth gilt. Printed on Art Paper. 3s. 6d.

'It is well adapted to interest young readers in nature.'-The Times.

'It is wonderful as a fairy tale.'-The Schoolmaster.

\section{Ponds and Rock Pools.}

\section{With Hints on Collecting for, and the Management} of, the Micro-Aquarium.

\section{By HENRY SCHERREN, F.Z.S.}

With many Illustrations. Crown 8 vo. Cloth gilt. 2s.

- A history of most of the inhabitants of ponds and sea-pools which are likely to fall under the notice of a young biological student.'-Academy.

- The author has a pleasant, staightforward style, and has avoided as far as possible the use of high-sounding names and language calculated to deter his unscientific readers from taking up the study of the contents of "Ponds and Rock Pools." He has produced a book full of helpful hints to the young collector, and one which should, we think, have the effect of causing many to strive to know more about the hidden beauties of Nature.'-Zoologist.

- The book is a delightful and instructive companion for the seaside or the banks of pond and stream, and should bring its possessors many happy and profitable hours.' - Scotsman.

\section{Popular Natural History for Boys and Girls.}

By W. J. GORDON.

With many Illustrations. Crown 8vo. Cloth. 2s. 6d.

- Facts are given in a way that awakes interest, and there is no lack of good stories. Boys and girls could not have a better introduction to one of the subjects which never fail to delight young and old. It is a book that ought to be in every house.'-London Quarterly Revicw.

- Imparts a great deal of trustworthy and up to-date information about all kinds of animals in a way that is strictly scientific as well as popular.'-Daily Telegraph.

- Admirably adapted to make the study of natural history popular with boys and girls.'-English Churchman.

"It is one of the best single-volume natural histories we have met with." Publishers' Circular.

LONDON: THE RELIGIOUS TRACT SOCIETY. 


\title{
Consider the Heavens: \\ A Popular Introduction to Astronomy. \\ By MRs. WILLIAM STEADMAN ALDIS. \\ With many Illustrations. Crown 8vo. Cloth. 2s. $6 d$.
}

Mrs. Aldis, who has written this little book under the eye of her husband, who was Senior Wrangler, starts with the view that its readers know nothing of astronomy. In clear, simple language, and with an abundance of illustrative examples, the marvellous and the fascinating and many of the difficult points of astronomy are made plain to the reader.

'We have no hesitation in recommending it as one of the best simple introductions to astronomical science we know.'-Glasgow Herald.

'Written by an authoress who has kept pace with the advance of science, and possesses a full knowledge of all the latest discoveries. Yet it is so lucid and simple that the most unlearned reader could not fail to derive from it a really useful know. ledge of astronomical facts.'-Church Times.

\section{The Royal Observatory, Greenwich: A Glance at its History and Work.}

\author{
By E. WALTER MAUNDER, F.R.A.S.,
}

Assistant at the Observatory.

With many Illustrations from Original Photographs.

Large crown $8 \mathrm{vo}$. Cloth gilt, gilt edges. $5 \mathrm{~s}$.

'The scientific work carried on at the Observatory is lucidly described.'Standard.

'An excellent popular book of science.'-Daily News.

' Not only a lively picture of the inside of the jealously-guarded Observatory, bnt 2 graceful sketch of a great part of modern astronomy.' -S pectator.

'Mr. Maunder's monograph has all the fascination which astronomy possesses, tven for those who understand nothing about it.'-Academy.

\section{The Midnight Sky.}

\section{Famillar Notes on the Stars and Planets.}

\section{By EDWIN DUNKIN, F.R.S., F.R.A.S.,}

Past President of the Royal Astronomical Society, late Chief Assistant at the Royal Observatory, Greenwich.

With 32 Star Maps and numerous other Illustrations.

New and thoroughly Revised Edition, with an additional Chapter and many New Engravings.

Imperial 8vo. Cloth, gilt top. 8s.

'Those little Maps of the starry spaces far surpass, in clearness and useful worth, all I have seen before in the planisphere way; no reader but by help of them may find, with a minimum of trouble, the star he seeks. ... Why did not somebody teach me the constellations too, and make me at home in the starry heavens, which are always overhead, and which I don't half know to this day ' - THOMAS CARLYLIE (referring to the first edition of this book).

For a study of the constellations nothing can be simpler than the system which Mr. Dunkin has adopted. One especially interesting chapter in the present volume is entirely new. It is an account of the principal observatories of the world, but especially of Greenwich Observatory, where for so many years Mr. Dunkin was chief assistant.' - School Board Chronicle.

' For any one who desires to study the face of the sky we can imagine no bettex present than this very handsome volume.'-Yorkshire Daily Post.

\section{LONDON : THE RELIGIOUS TRACT SOCIETY.}




\title{
The Honey Bee: \\ Its Nature, Homes, and Products.
}

By W. H. HARRIS, B.A., B.Sc.

With Eighty-two Illustrations. Crown 8vo. Cloth gilt. 2s. 6d.

- Contains a comprehensive and lucid account of its subject, written in an in. teresting style, and accompanied by numerous woodcut illustrations. No aspect of the subject, whether historical, scientific, or practical, appears to have been neglected by the author.'-Naturalist.

\section{Ants and their Ways.}

By the Rev. W. FARREN WHITE, M.A.

With numerous Illustrations, and a Complete List of Genera and Species of the British Ants.

Crown 8vo. Cloth gilt. 2s. 6 d.

'Will be of great assistance to any entomologist wishing to commence the study of our native ants; while as an interesting volume for the general reader, and as a gift-book for young people with a taste for natural history, it may be recommended as among the very best of its kind.'-Nature.

\section{Modern Ideas of Evolution as Related to Revelation and Science.}

\author{
By Sir J. W. DAWSON, C.M.G., LL.D., F.R.S.,
}

Author of 'The Chain of Life in Geological Time ;' 'Egypt and Syria : their Physical Features in relation to Bible History,' etc.

Sixth Edition. Revised and Enlarged.

Crown 8vo. Cloth gilt. 3s. 6d.

'It embodies the thoughts of an eminent geologist on some of the chief flaws and discrepancies in what he justly styles the "hypothesis" of evolution. If there is anything calculated to arrest the cocksure young scientist, who is always the young man in a hurry, this book will do it. Perhaps nothing but a counterblast-and Sir William Dawson's book is too well reasoned to deserve the term-can be expected to shake the unfaltering confidence of the middlemen of science, who purvey Darwinism, or what they consider to be Darwinism, to the intelligent multitude.'-Saturday Review.

\section{The Meeting Place of Geology and History.}

By Sir J. W. DAWSON, C.M.G., LL.D., F.R.S.,

Author of 'Modern Ideas of Evolution as related to Revelation and Science.'

With Illustrations. Crown 8vo. Cloth gilt. 5s.

-A popular exposition by a competent authority of the results of recent researches in the debatable ground intervening between the later part of the geological record and the beginnings of sacred and secular history. - Times. 


\section{BISHOP HANNINGTON \\ And the Story of the Uganda Miseion.}

Prepared by W. GRINTON BERRY, M.A.

With Map, Portrait, 3 Coloured and 4 other Illustrations, crown 8vo, cloth gilt, Coloured Medallion on Cover, 1s. 6d.

The personality of Hannington was full of colour and vigour, and the story of his work, particularly of his adventures in East Africa, ending with his martyrdom on the shores of the Victoria Nyanza, is cne of the most fascinating in missionary annals. Hannington was himself a picturesque writer, with a noteworthy gift of producing dashing and humorous descriptive sketches, and quite a third of the present volume consists of Hannington's own narratives. This volume will serve to sustain and deepen the perennial interest in Uganda, where the Gospel has won some of its most glorious triumphs.

\section{ALFRED SAKER \\ The Pioneer of the Cameroons.}

By his Daughter, E. M. SAKER.

With Map, 3 Coloured and other Illustrations, Coloured Medallion on Cover, crown 8vo, cloth gilt, 1s. $6 \mathrm{~d}$.

The Cameroons are a little known land, but they have been the scene of some of the most interesting work done by British missionaries on the West Coast of Africa. The land, like Sierra Leone, long justified the title of "The white man's grave." The people were savages, amongst whom it was not easy to work. The language was new, and Alfred Saker gave his life to this field. The story of his adventures and encouragements is singularly interesting.

\section{A DOCTOR AND HIS DOG IN UGANDA}

\section{From Letters and Journals of A. R. Cook, M.D.} Medical Missionary of the Church Missionary Society. Edited by Mrs. H. B. COOK.

With a Preface by Eugene Stock. Second Impression. With Photograph, Map of Uganda, and 12 other Illustrations, crown 8vo, cloth gilt, 2 s.

"With sincere pleasure I commend this little book. A great deal has been published from time to time on Uganda and the Uganda Mission, but this is the first book recounting the experiences of a Medical Missionary. To one who remembers the past history it is wonderful to read a book like the present."-Eugene Stock.

"This little book will be of interest to people other than those actively engaged in mission work, for the social and economic conditions of the country are by no means lost sight of."-Manchester Courier.

"We know of no other book which gives so vivid and realistic a picture of the daily life of the missionaries of Uganda."-Record.

\section{LONDON: THE RELIGIOUS TRACT SOCIETY.}




\section{JAMES CHALMERS}

\section{His Autobiography and Letters.}

By the late RICHARD LOVETT, M.A.,

Author of "James Gilmour of Mongolia," etc.

Seventh Impression. With 2 Maps and 8 Portrait Illustrations,

511 pages. Large crown $8 \mathrm{vo}$, cloth gilt, 3s. $6 \mathrm{~d}$. In padded paste grain, round corners, gilt edges, $6 \mathrm{~s}$. $6 \mathrm{~d}$. net.

"Altogether no brighter or more skilful narrative of missionary life -from the subjective as well as from the objective point of view-has ever been published than this."-The Spectator.

"It is the best missionary biography that has appeared during the last twenty years. It is a book that will live and take rank as a missionary classic. It is full of thrills, tremulous with pathos, glowing in its passion, and sublime in its tragic ending. A book to be read and re-read when the enthusiasm of humanity wanes, and we are tempted to let fireside heroics take the place of action."-The Daily News.

\section{GRIFFITH JOHN \\ The Story of Fifty Years in China.}

By R. WARDLAW THOMPSON, D.D. (Foreign Secretary of the London Missionary Society).

Fifth Impression. With Two Maps and Sixteen other full-page Illustrations. Demy 8vo, cloth gilt, 568 pages, 3s. 6d.

"No one can read this story without being inwardly refreshed. The mere adventure side of it is stirring to a degree. It reveals a Pauline daring and endurance."-Christian World.

"The story of Dr. John's life is a very fascinating one, and it is told by Dr. Wardlaw Thompson with much literary skill, and excellent taste and judgment."-The Westminster Gazette.

\section{W. HOLMAN BENTLEY \\ The Life and Labours of a Congo Pioneer.}

By his Widow, H. M. BENTLEY.

With a Photogravure Portrait, Map, and 19 other Illustrations, 466 pages, demy $8 \mathrm{vo}$, cloth gilt, $6 \mathrm{~s}$. net (by post, $6 \mathrm{~s} .5 \mathrm{~d}$.).

"This highly interesting memoir forms a worthy tribute to the honourable life and devoted labours of a notable pioneer of Christianity in Darkest Africa, who gave twenty-seven years to missionary work upon the Congo. .... The book forms an admirably interesting lifestory of successful mission work."-The Standard.

"Important in itself as the record of a notable, heroic and consecrated life, important also in the influence which it is sure to have on scores of young men and women in our Churches."-The Baptist Times.

LONDON : THE RELIGIOUS TRACT SOCIETY. 


\title{
THE BAGANDA AT HOME
}

With one hundred pictures of life and work in Uganda.

By C. W. HATTERSLEY.

80 full-page Illustrations, demy $8 \mathrm{vo}$, cloth gilt, $5 \mathrm{~s}$. net.

Mr. Hattersley knows more about Uganda and its people than any author who is just now before the public. Would you know the difference between the Uganda of Mtesa or the Uganda of King Daudi; or how the British administer Uganda; or how the Baganda live from day to day; or how the missionaries have given the people a system of education; or how they marry in Uganda; or how the sleeping-sickness is slaying its thousands; or how the Gospel has won some of the most striking results in the history of Christendom? Then this book will tell you.

\section{UGANDA BY PEN AND CAMERA}

\author{
By C. W. HATTERSLEY.
}

Second Impression. With a Preface by T. F. Victor Buxton, 34

Illustrations, large crown $8 \mathrm{vo}$, cloth gilt, $2 \mathrm{~s}$.

"The narrative is a vivid and soul-stirring record of one of the most remarkable movements in the annals of missionary enterprise." Christian.

"Mr. Hattersley's book is full of interesting details, from which one may get a clear idea of the country and its people."-Spectator.

\section{AMONG THE TIBETANS}

By ISABELLA L. BISHOP, F.R.G.S.,

Author of "Unbeaten Tracks in Japan," etc.

With 22 Illustrations, crown 8vo, cloth, 1s. $6 \mathrm{~d}$. ; also in paper cover, $1 \mathrm{~s}$.

"This is one of the brightest, most life-like, and most perfectly balanced of Mrs. Bishop's works."-Spectator.

"A delightful book of travel, characterised by all the distinguished writer's purity of style, vividness of description, and attention to detail, which make her books so interesting and useful."-Record.

\section{THE CROSS IN THE LAND OF THE TRIDEN -}

\section{Or, India from a Missionary Point of View.}

By HARLAN P. BEACH.

Crown 8 vo, cloth, $1 \mathrm{~s}$.

"The trident, the three-pronged fork, which appears in every Siva temple in India, has come to be regarded as the symbol of the Hindu religion. This little book deals with missionary work in India, but is in no sense a narrative. It, however, contains much matter which will prove attractive to ordinary readers."-English Churchman.

LONDON: THE RELIGIOUS TRACT SOCIETY. 

RETURN TO the circulation desk of any University of California Library

or to the

NORTHERN REGIONAL LIBRARY FACILITY

Bldg. 400, Richmond Field Station

University of California

Richmond, CA 94804-4698

ALL BOOKS MAY BE RECALLED AFTER 7 DAYS

- 2-month loans may be renewed by calling (510) 642-6753

- 1-year loans may be recharged by bringing books to NRLF

- Renewals and recharges may be made 4 days prior to due date

\section{DUE AS STAMPED BELOW}

MAY 182007 

